UNITED STATES DEPARTMENT OF INTERIOR

GEOLOGICAL SURVEY

\title{
ANALYTICAL DATA FOR MINUS-80-MESH STREAM-SEDIMENT SAMPLES COLLECTED DURING 1981 FROM THE SOLOMON AND BENDELEBEN QUADRANGLES, ALASKA
}

\section{by}

H. D. King, S. J. Sutley, and C. M. McDougal

Open-File Report 82-964

1982

This report is preliminary and has not been reviewed for conformity with the

U.S. Geological Survey editorial standards. 


\section{CONTENTS}

Page

Introduction-1.--

Sample collection, preparation, and analysis-

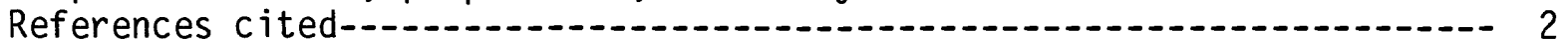

\section{ILLUSTRATIONS}

Plate 1. Sample site locality map of the Solomon quadrangle, Alaska-.-...... In pocket

Plate 2. Sample site locality map of the Bendeleben quadrangle, Alaska-... In pocket

\section{TABLE}

Table 1.--Semiquantitative spectrographic and atomic-absorption analyses of minus-80-mesh stream-sediment samples, Solomon and Bendeleben quadrangles, Alaska-............... 


\section{Introduction}

A geochemical survey was begun in the Solomon and Bendeleben quadrangles, Seward Peninsula, Alaska during 1981 as part of the Alaska Mineral Resource Assessment Program. This report presents analytical data (table 1) for 592 minus-80-mesh $(<0.177 \mathrm{~mm})$ stream-sediment samples collected during 1981 . Additional sampling is planned for 1982. Access to sample sites was gained by use of a helicopter. Sample site locations are shown on plates 1 and 2 .

Sample numbers, given in table 1 , coincide with site numbers shown on the maps (plates 1 and 2). The site numbers may be obtained from sample numbers by removing the prefix SB, leading zeros, and the suffix S. For example, the site where sample number SB001S was collected is indicated by a dot on the map next to the number 1 .

In table 1 , results are given in parts per million (ppm) except for those given for $\mathrm{Fe}, \mathrm{Mg}, \mathrm{Ca}$, and $\mathrm{Ti}$, which are in percent (pct.). Lower and upper limits of determination are given in the table where applicable. Symbols used in the tables are as follows: <, an undetermined value less than the value shown was detected; $N$, not detected; $>$, an undetermined value greater than the value shown was detected. The symbols "s" and "aa" in the column headings indicate the method of analysis as follows: s, spectrogrpahic analysis; aa, atomic absorption analysis.

All of the analytical data have been entered in the U.S. Geological Survey's computerized analysis storage system (RASS) (VanTrump and Miesch, 1977).

Sample collection, preparation, and analysis

Most of the samples were collected from the active portions of first and second order streams. Minus-2-mm stream sediment was collected for the stream-sediment samples by wet sieving at the sample site with a stainless steel screen. Most samples were air dried in the field; some samples were further dried in an oven at the laboratory. After drying, the samples were sieved with an 80-mesh screen and the <80-mesh fraction was pulverized to minus-150-mesh $(0.105 \mathrm{~mm})$ in a vertical grinder using ceramic grinding plates. The samples were analyzed semiquantitatively for 31 elements using a six-step emission spectrographic method outlined by Grimes and Marranzino (1968). The spectrographic results were reported as geometric midpoints, 1.0, $0.7,0.5,0.3,0.2,0.15$, (or appropriate multiples of ten) of geometric brackets having the boundaries $1.2,0.83,0.56,0.38,0.26,0.18,0.12$ (or appropriate multiples). Samples were also analyzed for gold using an atomicabsorption method described by Ward and others (1969). Spectrographic analyses were done by G.W. Day and S. J. Sutley. Atomic-absorption analyses were done by J. D. Hoffman, R. M. O'Leary, D. M. Hopkins, and Anna Mantei. K. A. Duttweiler, D. W. Johnson, and H. E. Dawson assisted in sample collection. 
Grimes, D. J., and Marranzino, A. P., 1968, Direct-current arc and alternating-current spark emission spectrographic field methods for the semiquantitative analysis of geologic materials: U.S. Geological Survey Circular 591, 6 p.

VanTrump, George, Jr., and Miesch, A. T., 1977, The U.S. Geological Survey RASS-STATPAC system for management and statistical reduction of geochemical data: Computers and Geosciences: Great Britain, Pergomon Press, v. 3, pp. 475-488.

Ward, F. N., Nakagawa, H. M., Harms, T. F., and VanSickle, G. H., 1969, Atomic-absorption methods of analysis useful in geochemical exploration: U.S. Geological Survey Bulletin 1289, 45 p. 


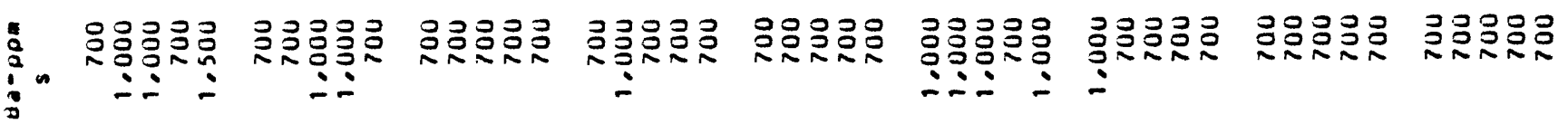

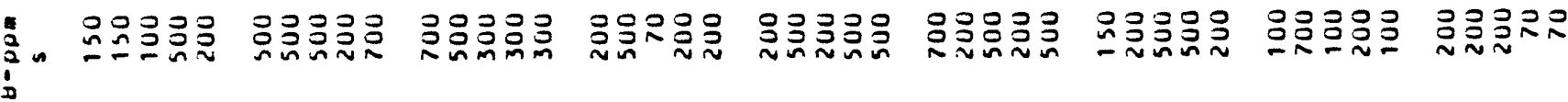

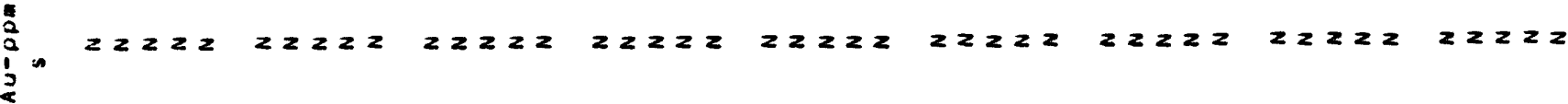

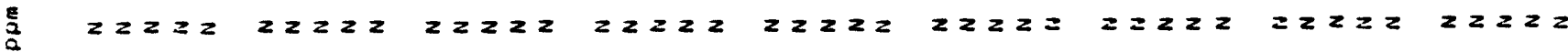
in $\frac{1}{2}$

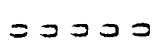

고ํำ

고ㄱㅜㅜ뭉요

3오옹 -innio

ínin

윰Rㄹ

코류ำ

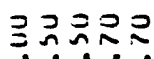

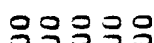

i

ำํํำ vivin

ن무

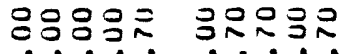
in

>0ว

?ำ?

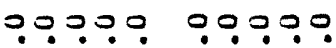

0.00ㅇ 00??0

$0.00 \% 0$

$?: 0 ?$

ำำ

?:99: - inina nntion

$\ln \pi \sin$ กันก

$\supset \cap ว \backsim \cap$

-ㅇํำำ

그늘를

ㄱำ จn 영요 m요음

$\simeq \sim \simeq \tilde{n}$ - $\infty \pi-$

그ํํํ욤ำ

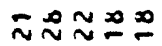

mo:

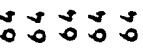

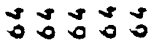

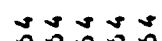

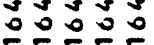

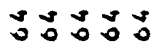

그ำำ

이응

ํํำงั0ง

กำำกำ

=N요

ำกำก

m㶽品品

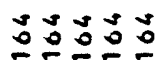

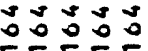

도은

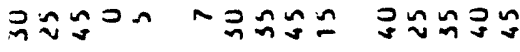

글ㄹㄹ

oง

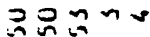

คด ฏฺก

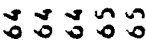

$\infty \infty \sim \infty$

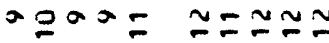

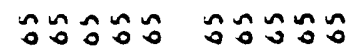

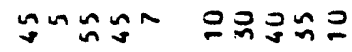

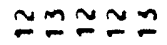

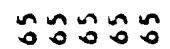

ニニヘッニ

$\tilde{0} \tilde{0} \tilde{0} \tilde{0}$
maN

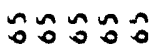

$\log 2$ Iiㅛ ํำำำ

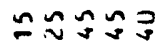
$\simeq \supseteq \operatorname{nก}$

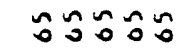

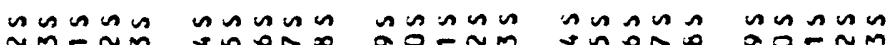

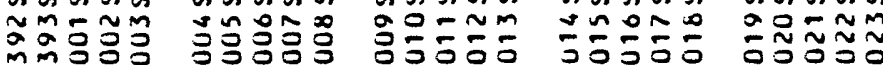

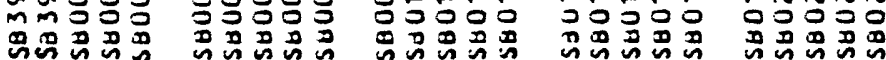

$n \sim n n u$ $\sim \sim \sim \sim \sim \sim ⿻ 上$

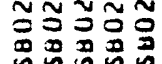

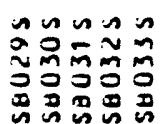

n日勺un 노ํํำ 品范㤩品

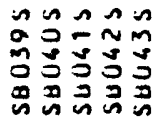




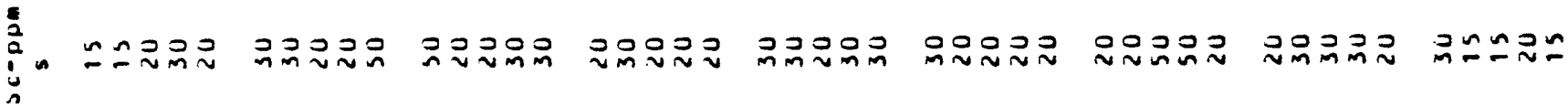

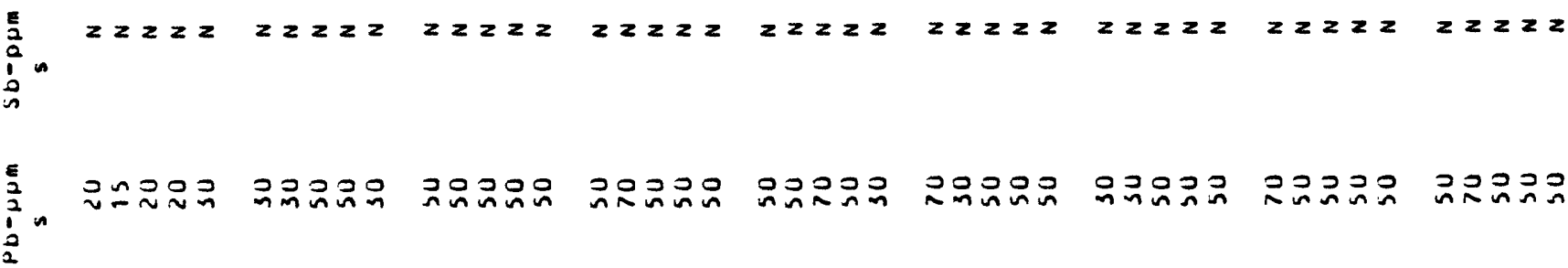

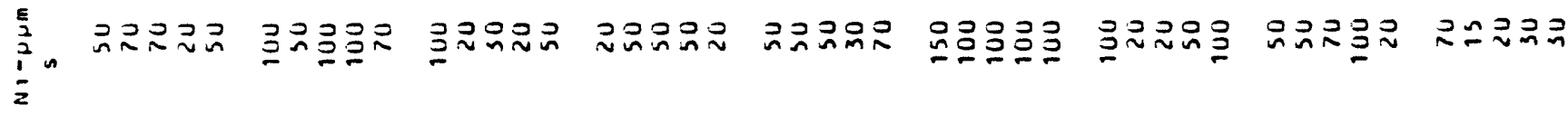
$\frac{5}{2}$
$\frac{1}{2}$ in

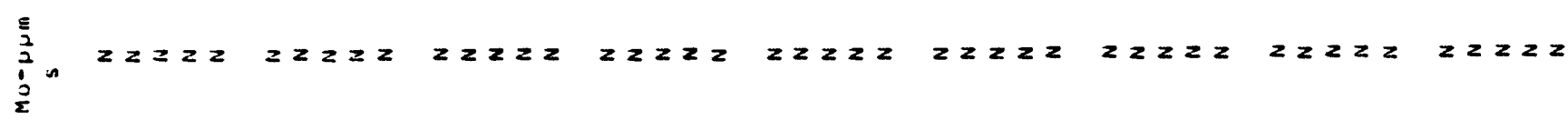

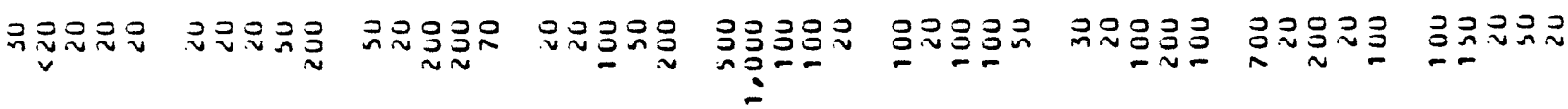

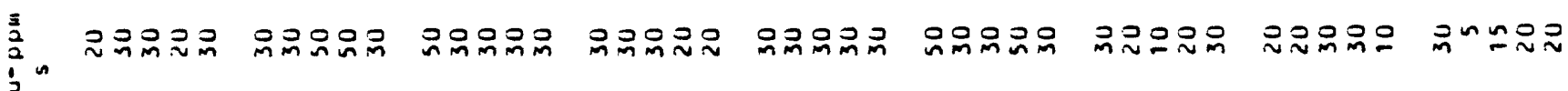
竞

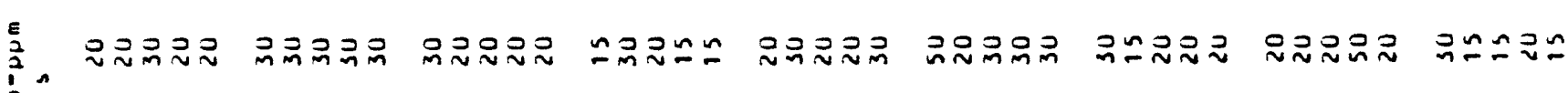
is

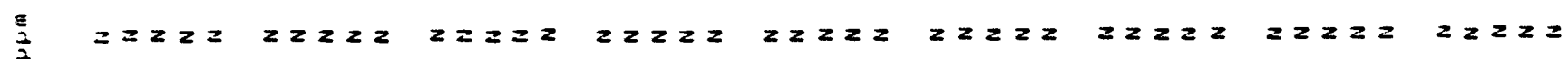

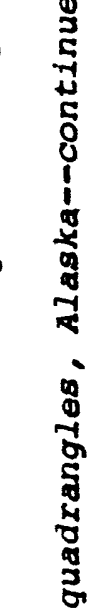

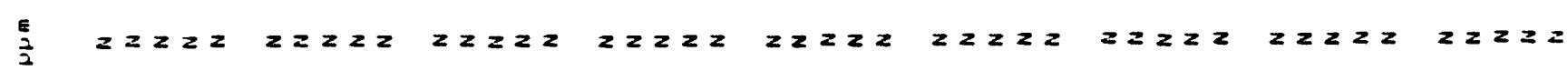
(a)

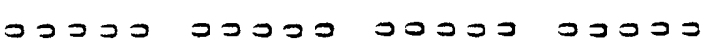
$\stackrel{1}{\vdots}$ मํํํำ

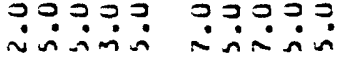
ำ?ำ? ำ?ำ? ?????

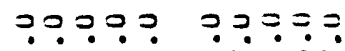

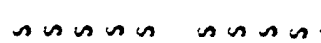

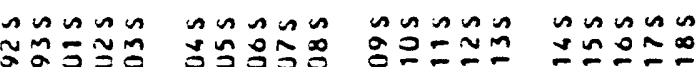

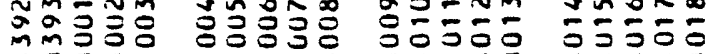

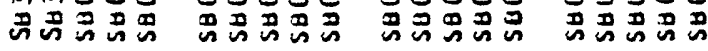

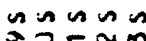
$\underline{\sim} \tilde{\sim} \tilde{N}$

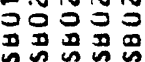

กิน $\tilde{\sim} \approx \sim \sim \sim ⿻ 上 丨$ ว0ว00

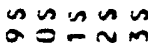

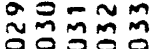
品范录品

นnก

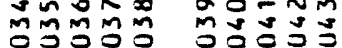

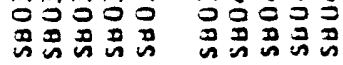


戛

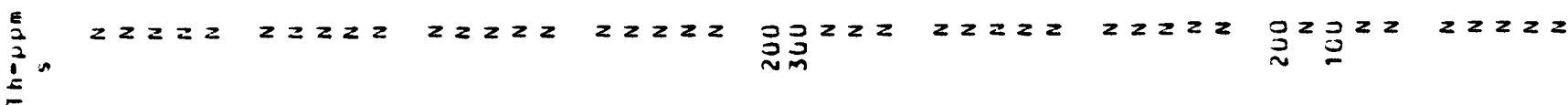

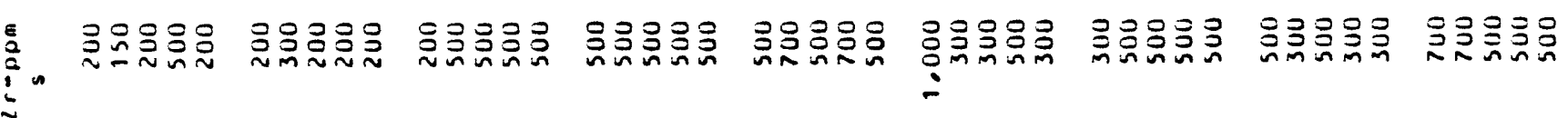

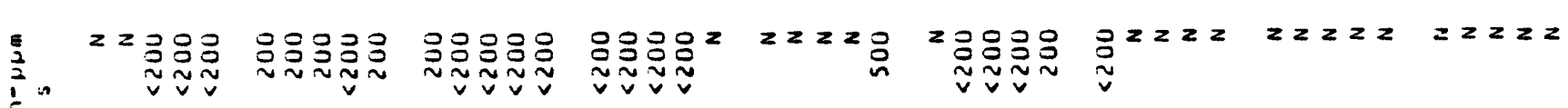

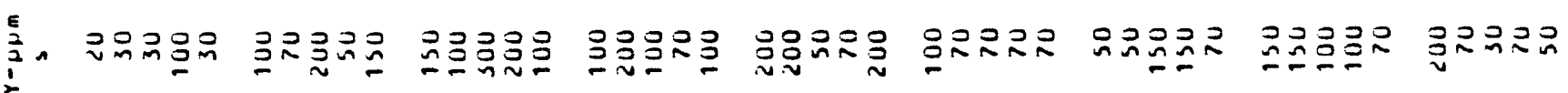

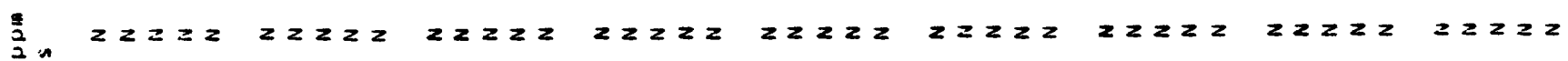
3

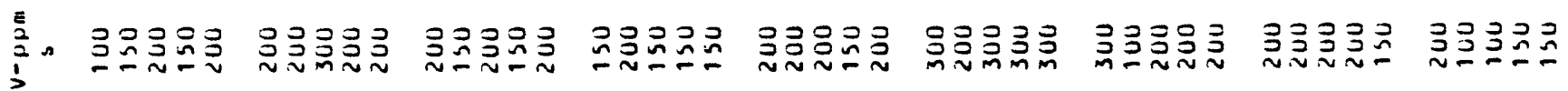

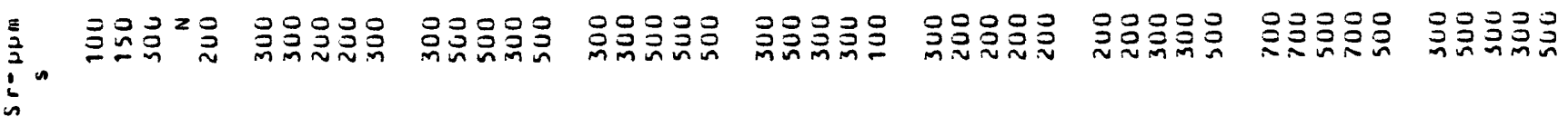

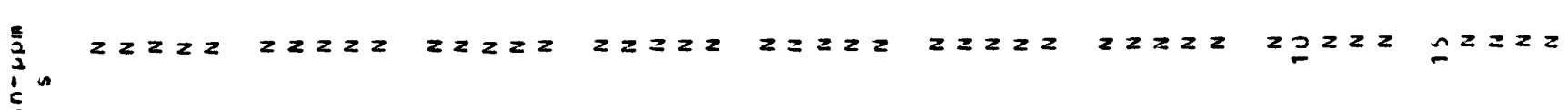

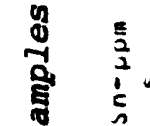

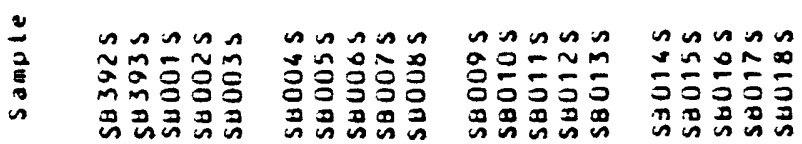

$\sin \approx \tilde{n} \tilde{a}$

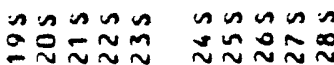

$\sin \sin \sin \sin \sin \sin \theta$

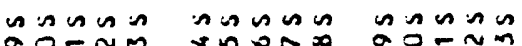

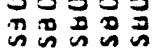

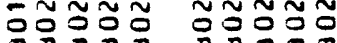

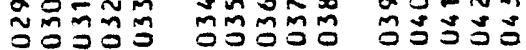

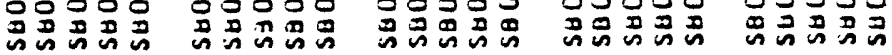




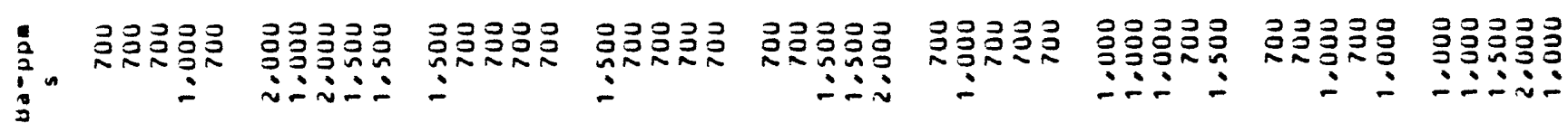

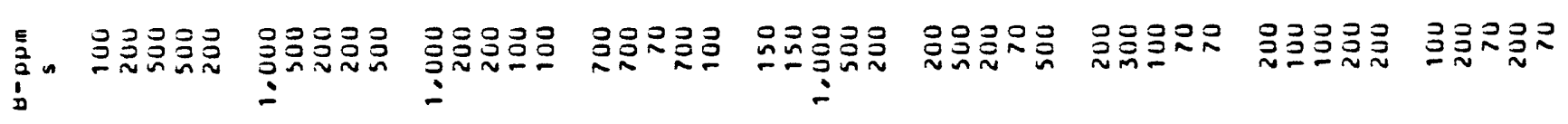

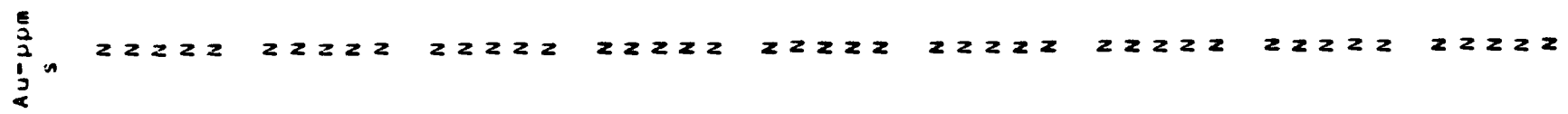

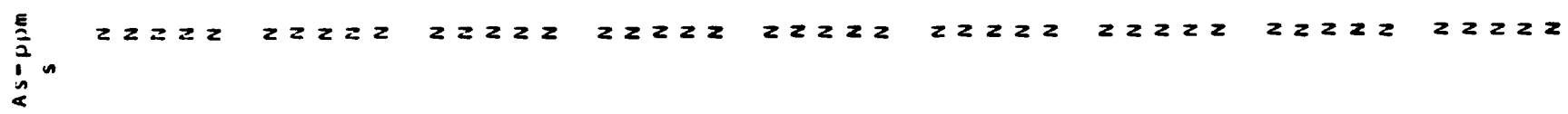

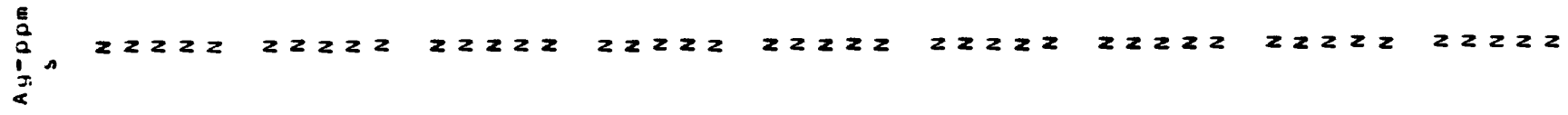

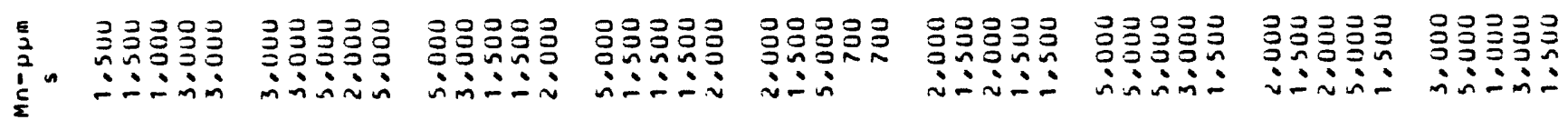

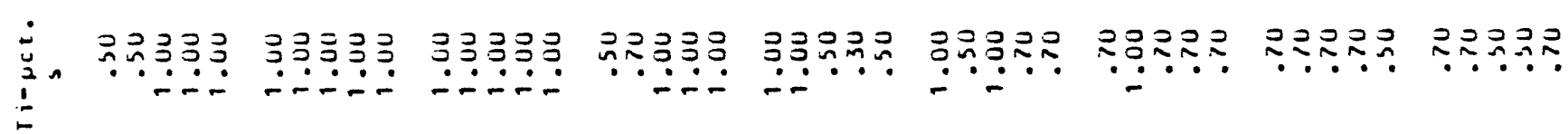

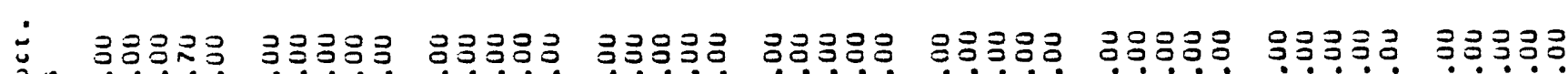
n is

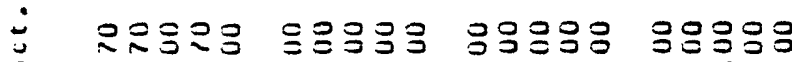

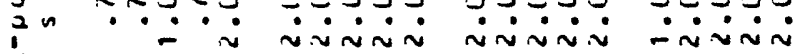
$\sim \sim \sim \sim \sim$

옹응ㅇㅁㅇㅇㅇ 응응응

응옥옥

옹오요

응옹용 $\frac{\pi}{2}$ iñن்miñn

NNimm

$\dot{\sim} \dot{\sim} \dot{-} \dot{m}$

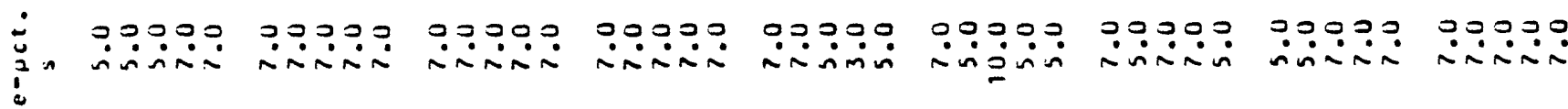

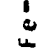

กิํํำ 그ํํํำ

$\sum^{2} \supset \tilde{n} \sim \tilde{n}$

moน

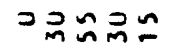

$\operatorname{Nin}_{m} \sim \sim$

$00 \hat{m} \sim n$

$\approx$

ñก⿻上丨

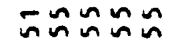

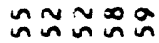

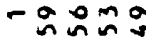

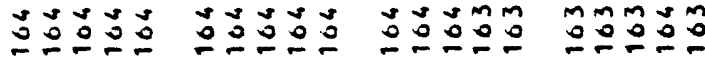

mimmm

mion?

:ดตฺต

$\stackrel{\sim}{\sim} \sim \mathcal{m}$

$\pi \sin ^{2} \sim \pi$

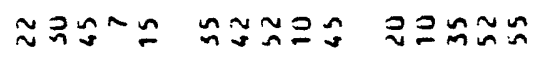

ำน ณี

ำกำำ

$\partial \tilde{\sim} \tilde{\sim} \tilde{n}$

$\pi \sin ^{2}$

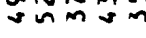

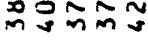

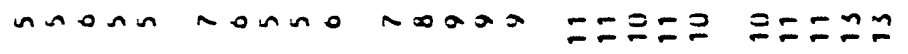

$\simeq \simeq \simeq \infty$

no 0000

$\curvearrowleft$

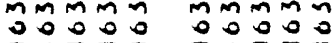

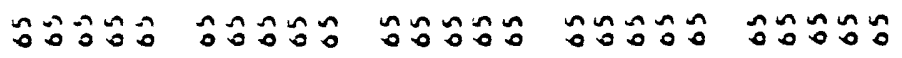

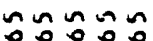

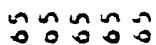

ดน $\sim$ ?

ำร

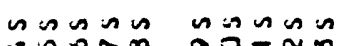

กนกฺn nก⿻上丨

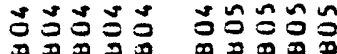

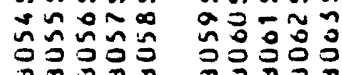

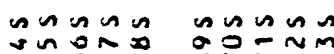

ㅇํㅇㅇํㅇㅇํㅇ

จิ์

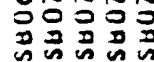

แก คูก

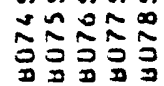

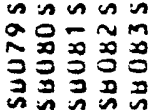




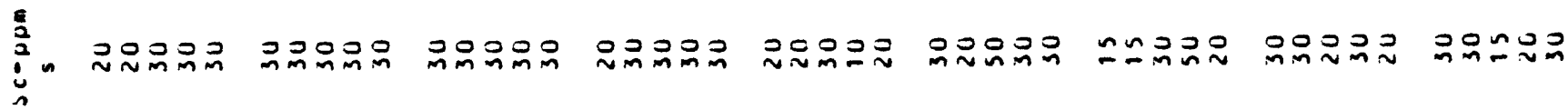

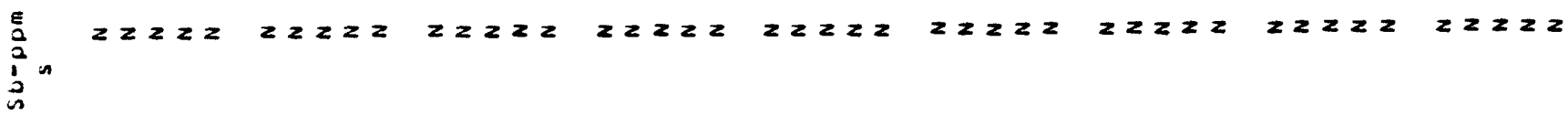

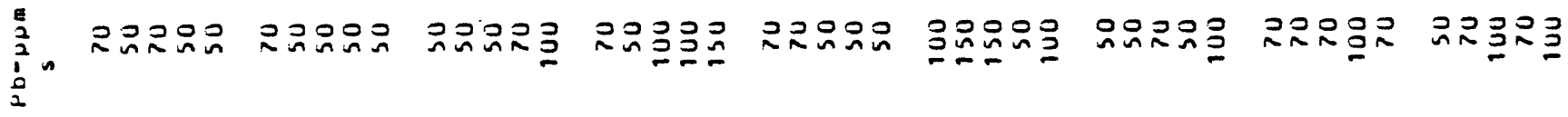

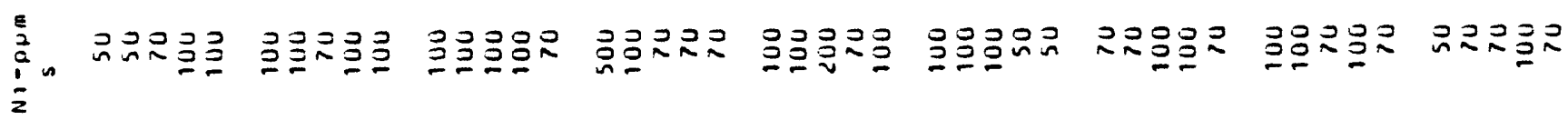

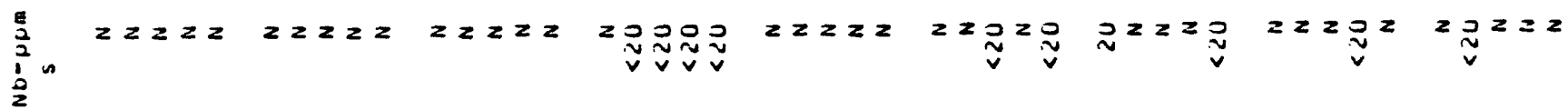

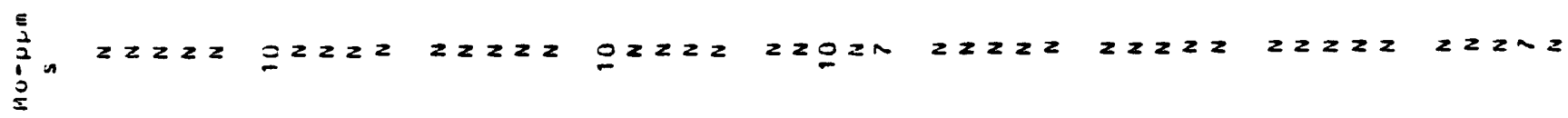

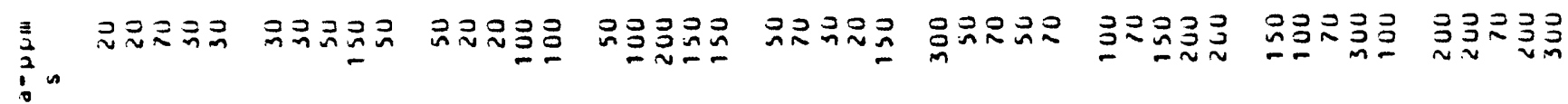

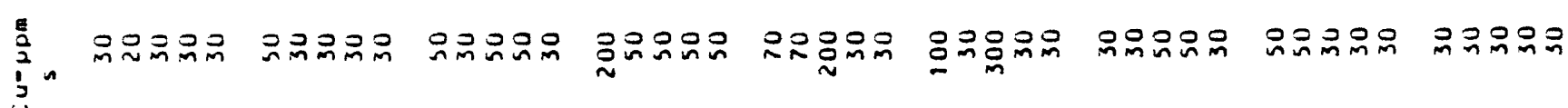

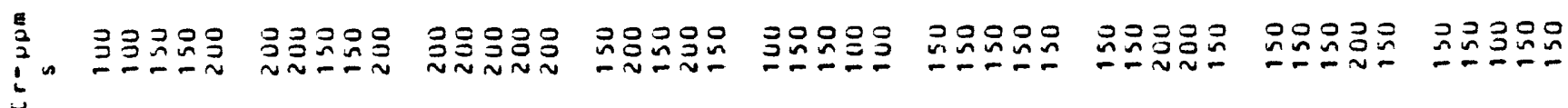

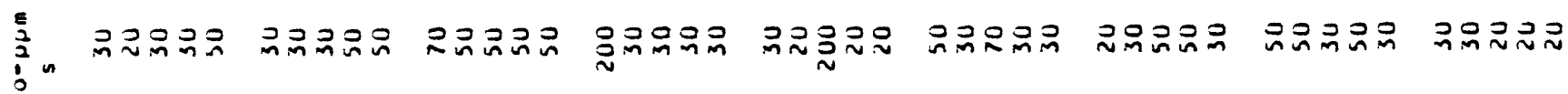

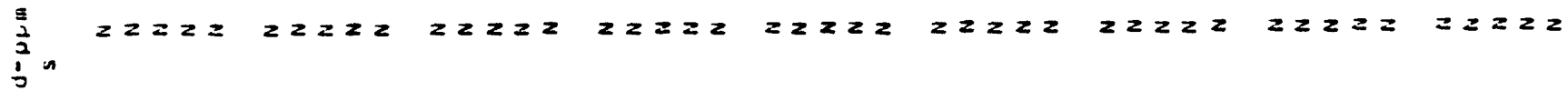

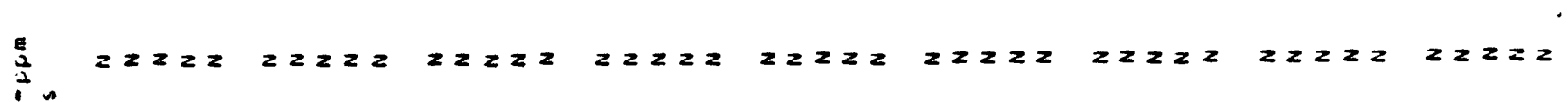
$\vdots$ 茛 
焉:

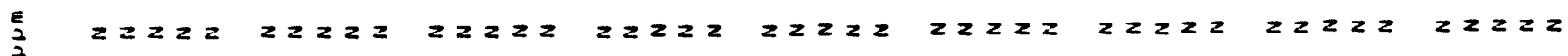
$\underline{2}$

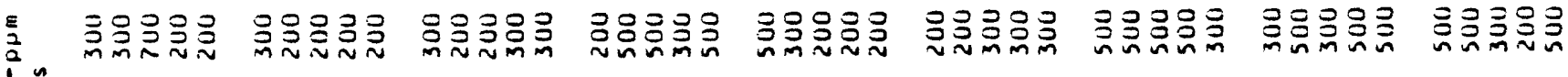

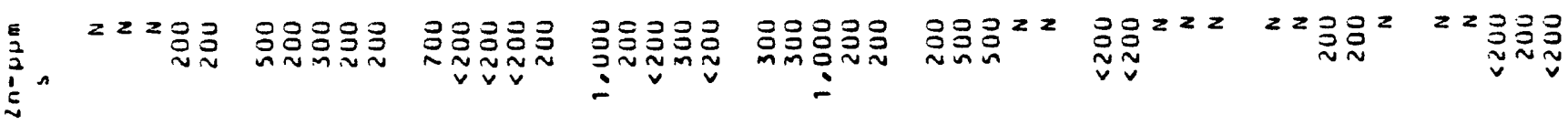

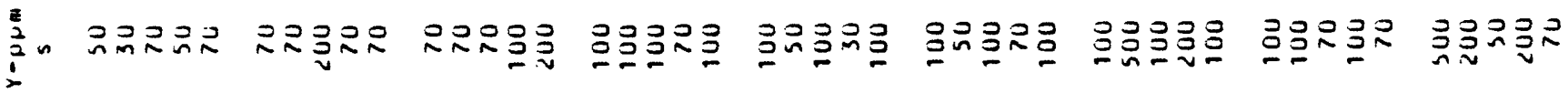

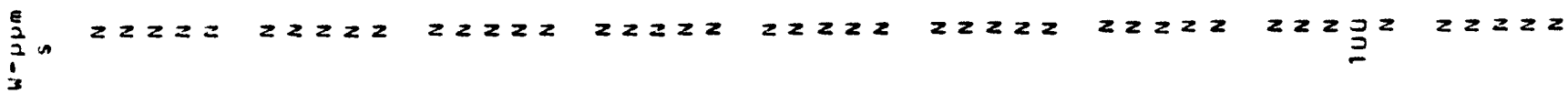

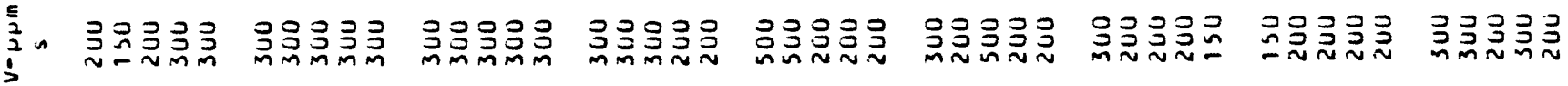

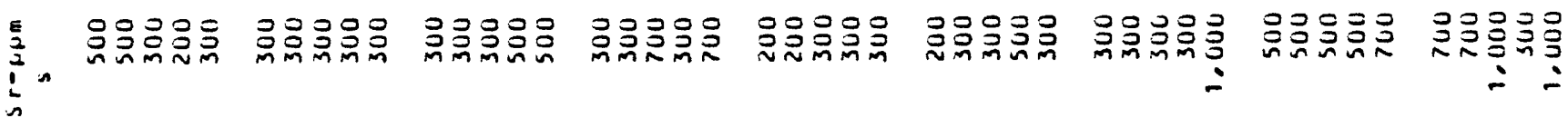

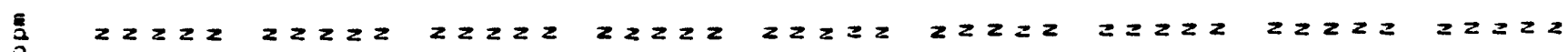
$i^{2}$

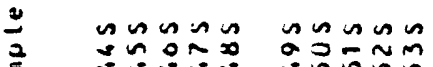

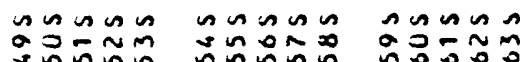

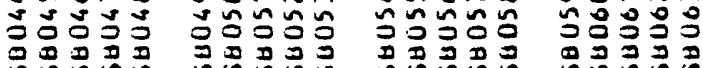

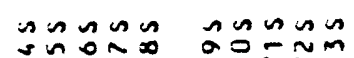
ธิธีㅇํㅇㅇำ gR๊ก̃

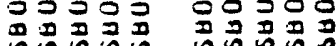

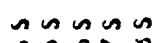
ํำำำ 解品星

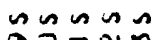
可要范

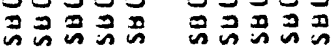




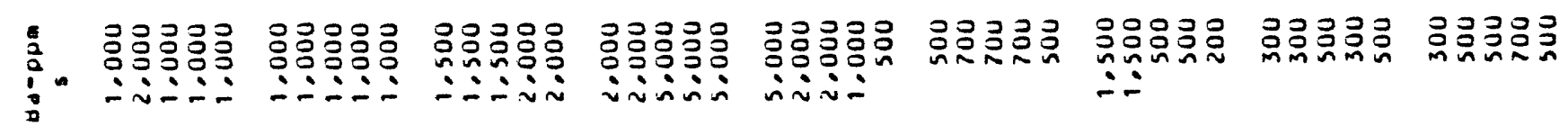

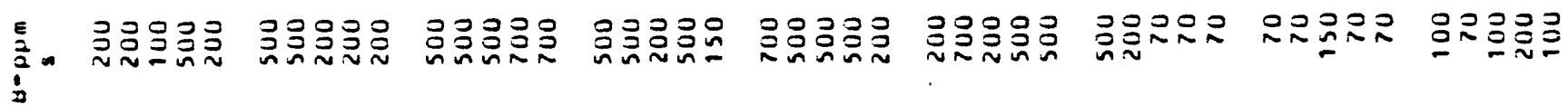

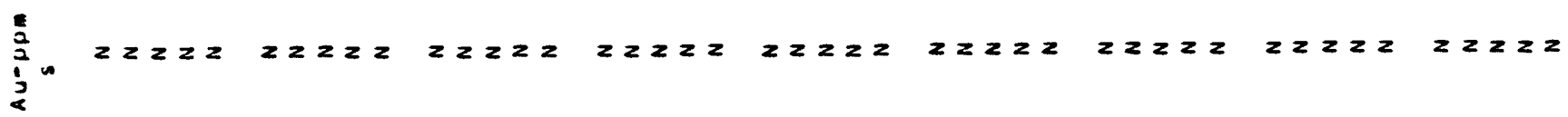

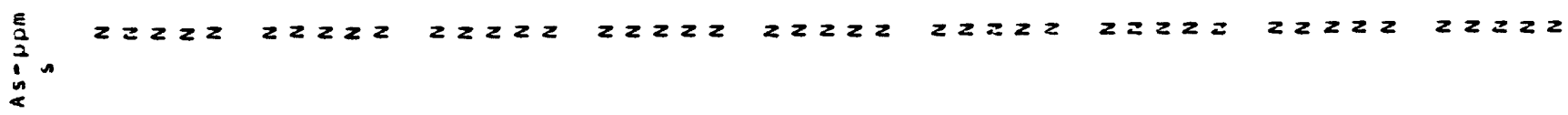

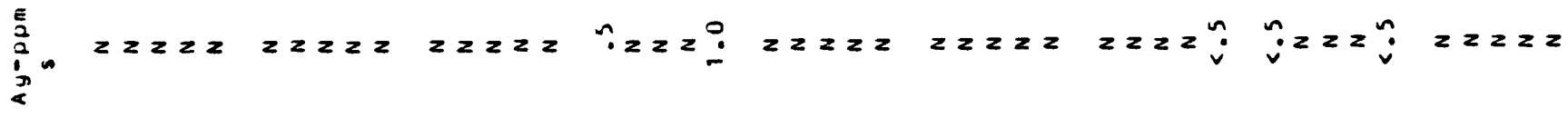

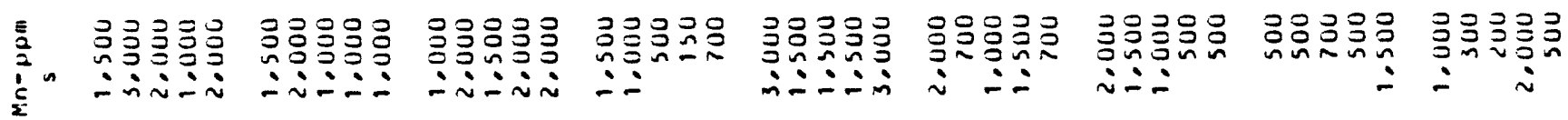
道 $\underline{1}$

$\vdots$

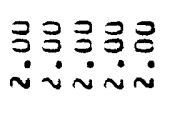
ํํํํํํำ

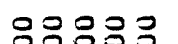

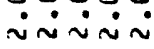
i完完 aoo

\section{bopos 50000}

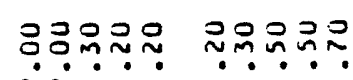

รำํำำ 3

立 옹오을 ๖९८९९ 몸ํํ요 옹오 ำํำ

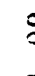

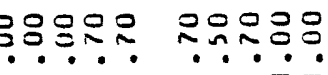
อำะ

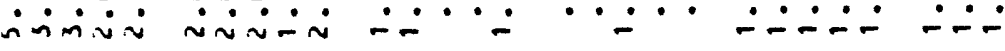

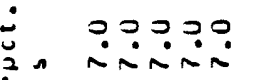

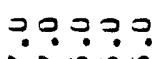
0.9000. 0.3000

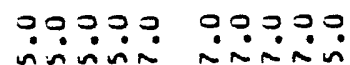

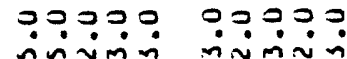

op?os. : Nining nninum ninunivin numuna nanana

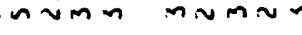

inmav

วรำำ

ํํํำ 워ㅇㅝㅛ ระ⿻ำ约 嘢品品

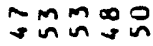
두로ํํำ 00ะกำ ที丶万กำ ๓กะะกะ nn MmMmM mmmm manma ํㅗㅇㅡ

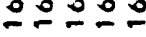

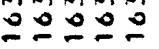
วุำ? 只品品品 smatos ñกㄴำ masga

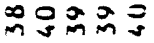
กวูกูบ ํำำกำ วnวn m.ด.

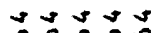

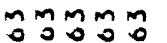
लिखिए? ำำำ $\Xi \Xi \Xi \simeq M$ $\simeq \simeq \dddot{2}$ $\simeq 00 \infty \infty$ $\sim コ ー 2$ $\approx n \supset \approx n$

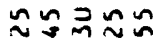
ñgn

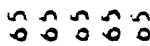

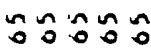

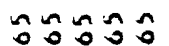

ก

$\simeq \approx 0 \simeq \simeq$

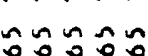
$\simeq \cong 00 \tilde{n}$

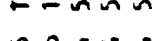
กำำก กิํำกำก $\tilde{n} \sim 0 \equiv$

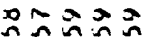
(1)

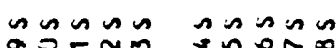

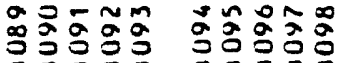

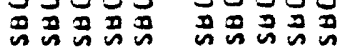

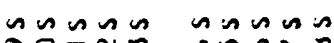
ํํำำำำํำำำ

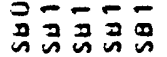

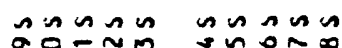
응ニㅡ

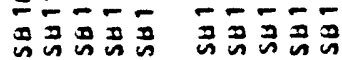

aอก $\underline{N} \tilde{\sim} \sim$

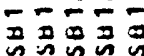
$\tilde{\sim} \approx \sim \sim \sim ⿻ 上$ 可牙正 an n n n n
ลูกินกี ำตำ

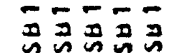




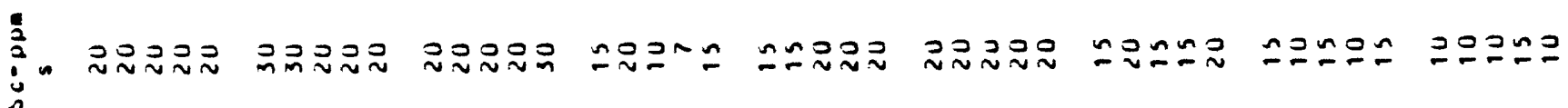

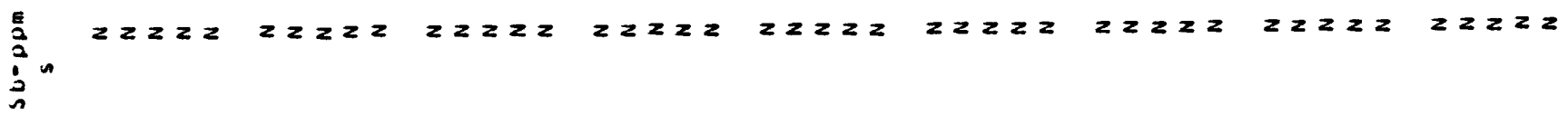

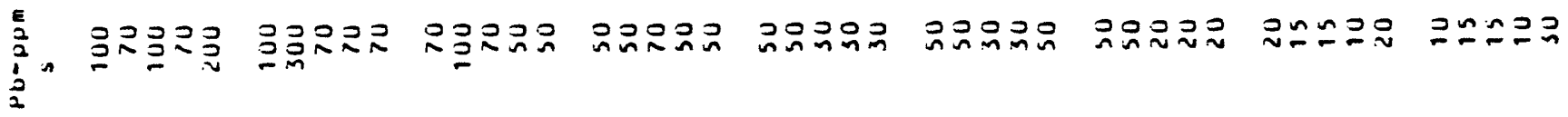

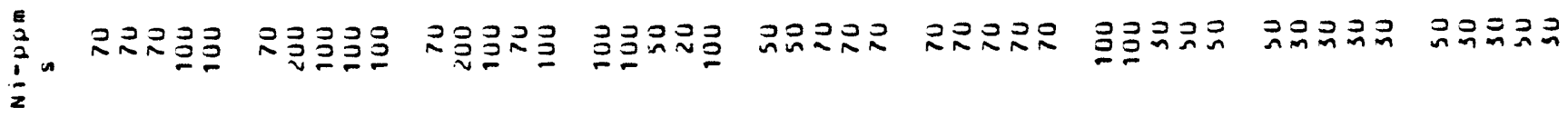

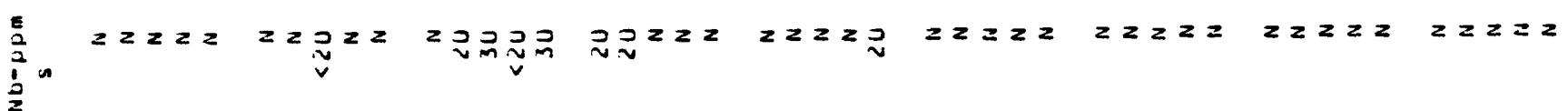

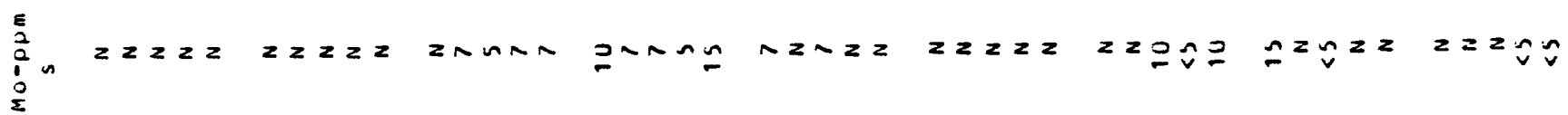

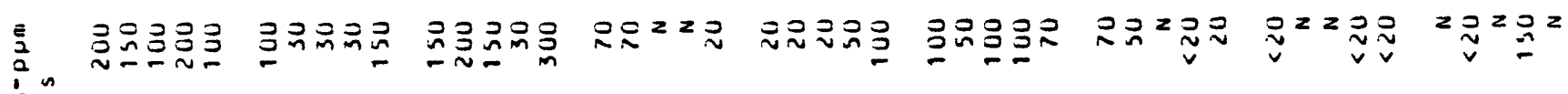
jo

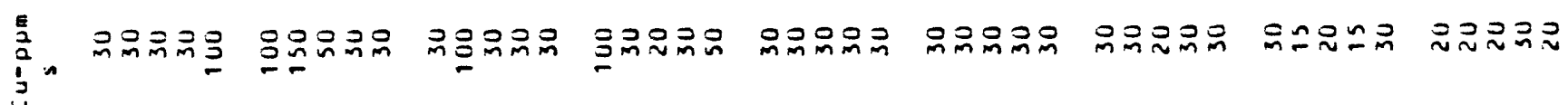

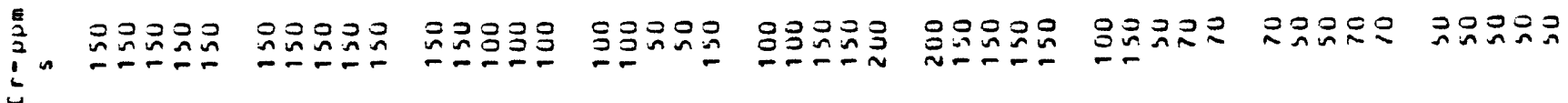

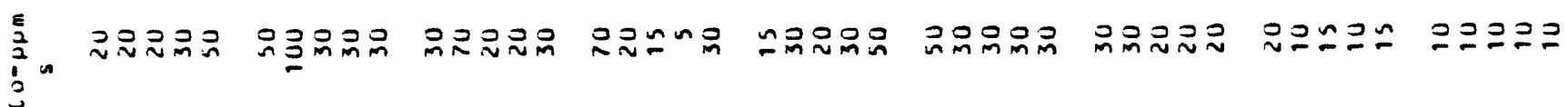

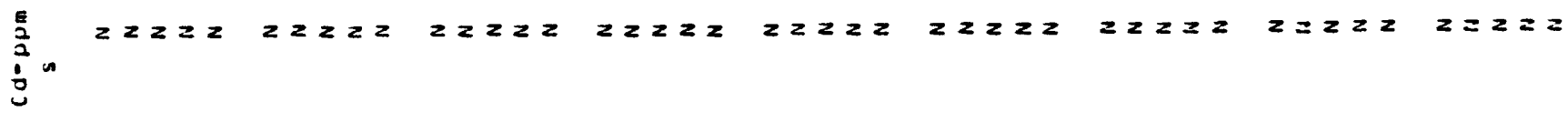

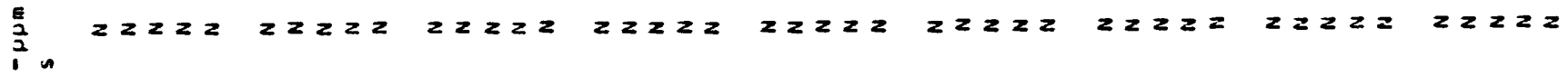
3

告

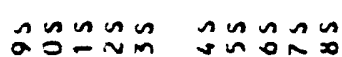

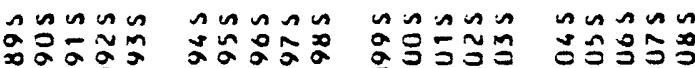

oำำ

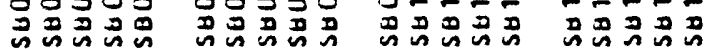

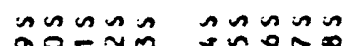

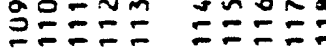

และกn

$2 \approx \Sigma \approx \sim ⿻ 上 丨$

$\sim \tilde{N A \hat{\infty}}$

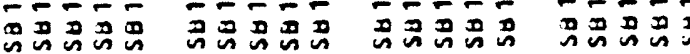

กินกี ํํำก

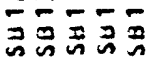


吾:

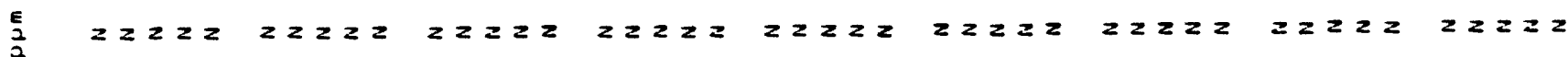
$\stackrel{1}{=}$

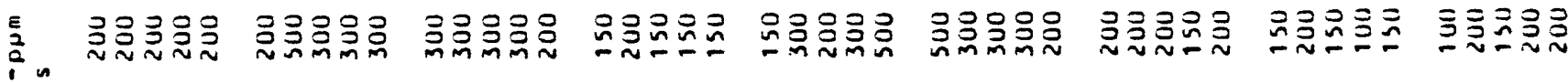

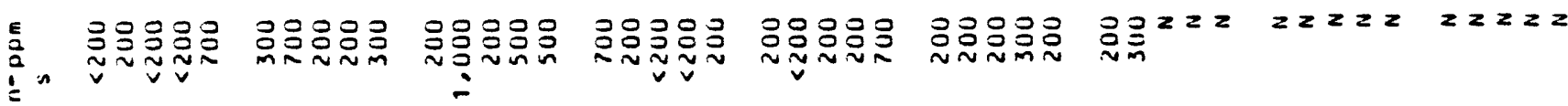
$\stackrel{n}{n}$

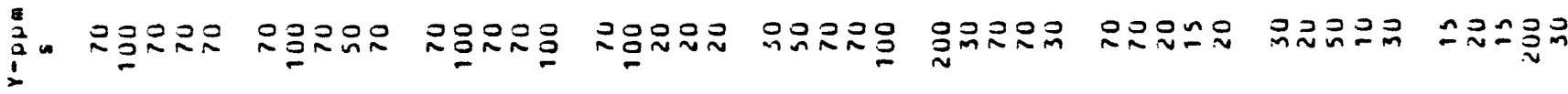
否

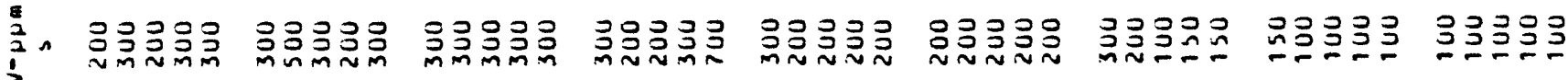

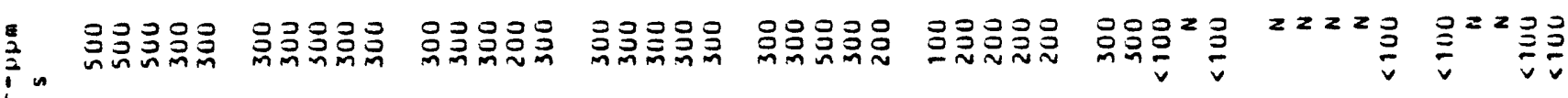

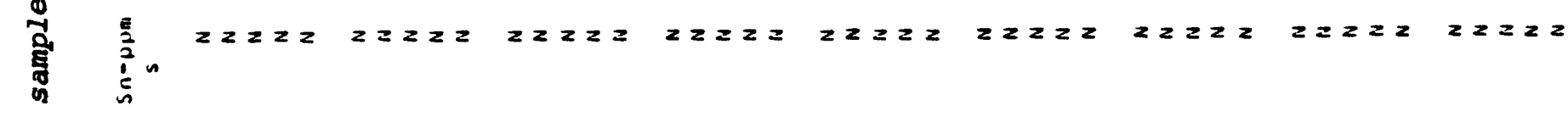

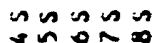

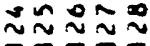

n $n$ 舟 $n$

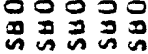

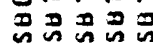

可可

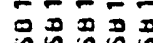

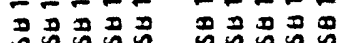

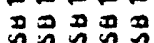

จำกำ

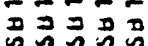




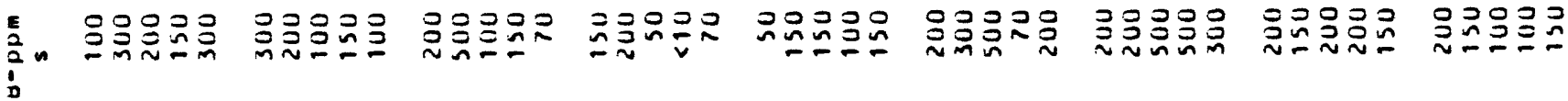

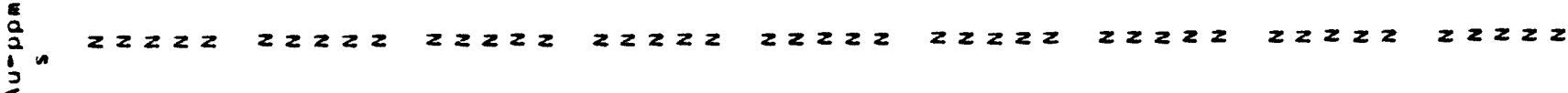

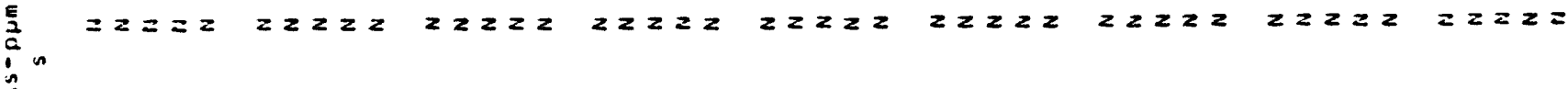

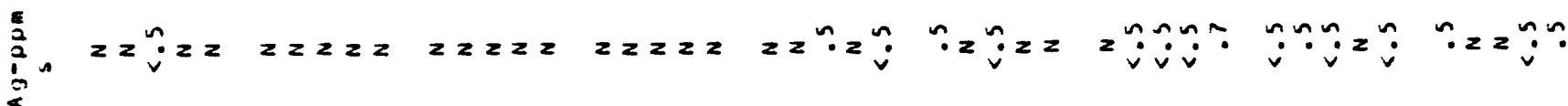

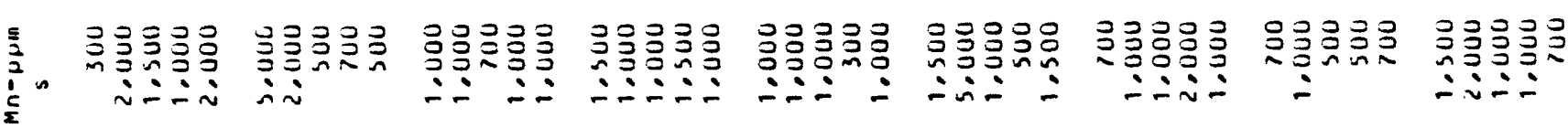

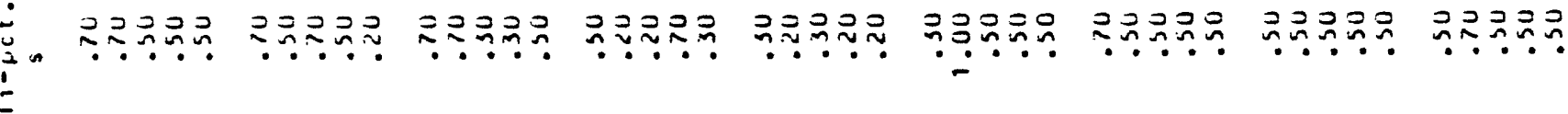

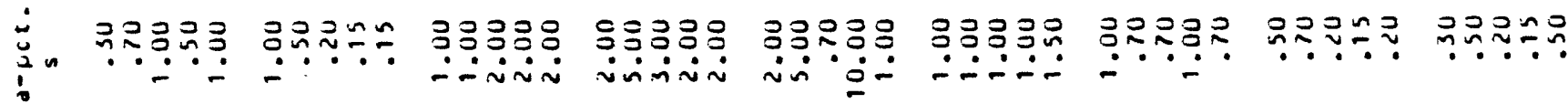

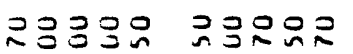
욤요응 윽옹옹요 응응무

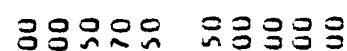
ว옹ํำ ว马马 $\because \because \because \because \because \because$ in $\because \dot{\sim} \sim \dot{-}$ $\therefore \dot{\sim} \dot{\sim} \dot{-1}$ $\because \because \because \because \because \because \div$ $\because \therefore \therefore$ $\because \div-$

$0=00$

00000

$0 ? 000$

?กวด?

0.990

0.0000 ?.?0?0.

0.? 00.

$00 ? 30$ in $\sin$ กิnกับ ขึinin

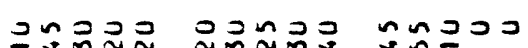

วงกำ

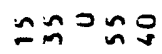

品的喝品

ำกำะ

ก $\sin 3 n$

$\supseteq 0 \sim 2 n$

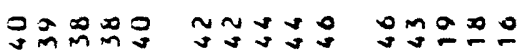
エッュ ำกテล ำง ำง

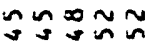
敬品品品

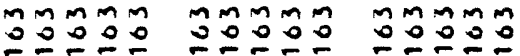
minmm mMmmm Amming mmmmm

mummn -nm-j ำ-

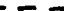

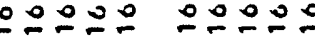

ヘேำำ

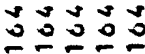

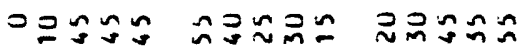

ลีงจะอ

วกนกร

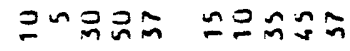

$\approx \approx n \sigma \approx$

จํำว

-.- n monomán uñ

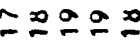

뽕ํㅇ

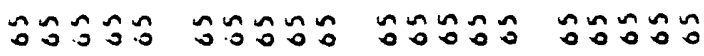

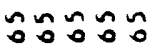

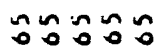

nunso nonoman

nกmm

m $\sim \mathcal{A}$

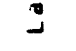

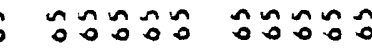

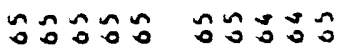

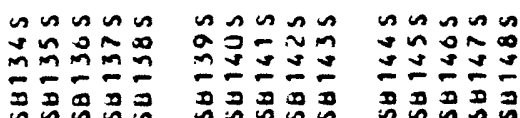

$\hat{\alpha} \cos \approx n$

oำ

$\sin n \sin$

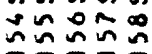

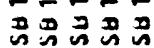

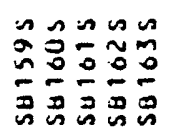

กn

ป์ำำ:

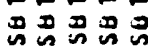

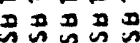

son $\sin x$

ดลำ

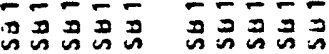




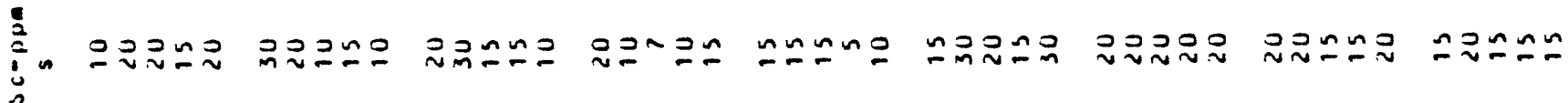
E

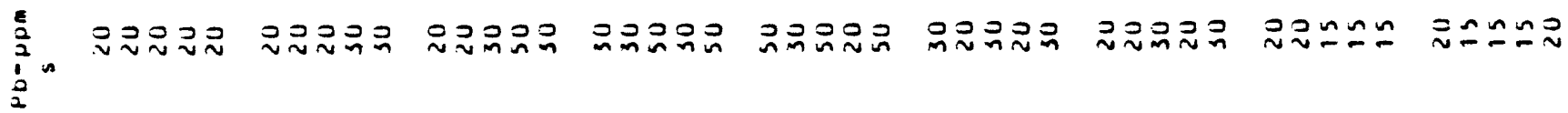

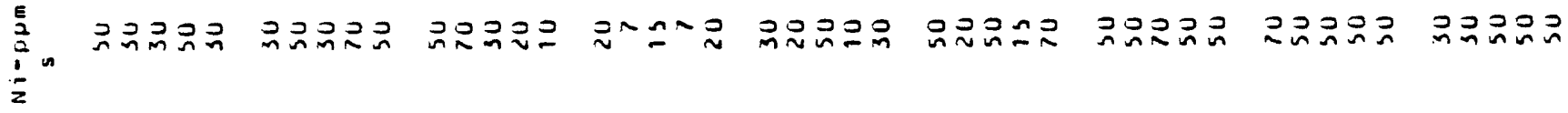

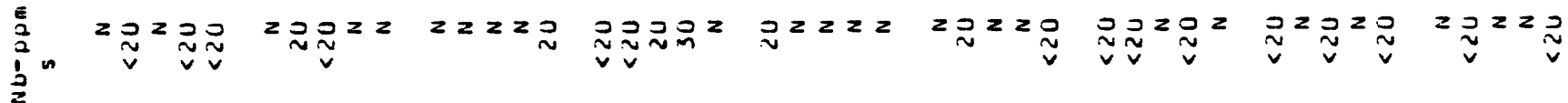

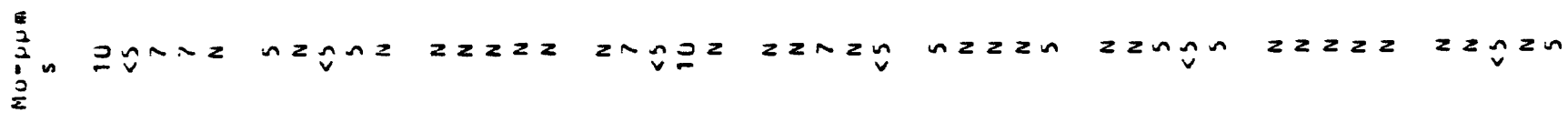

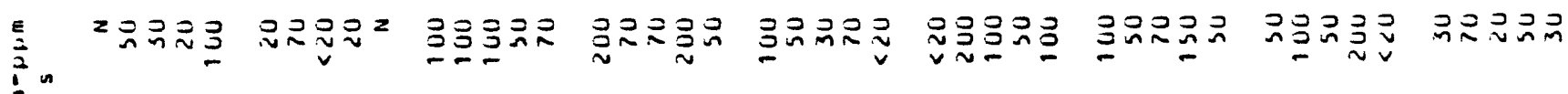

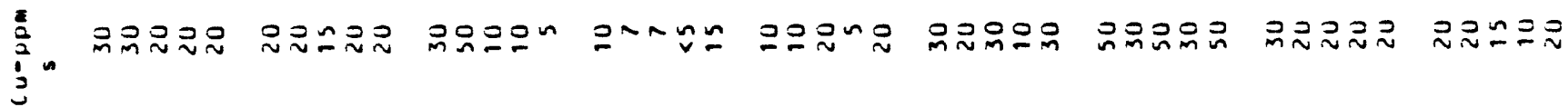

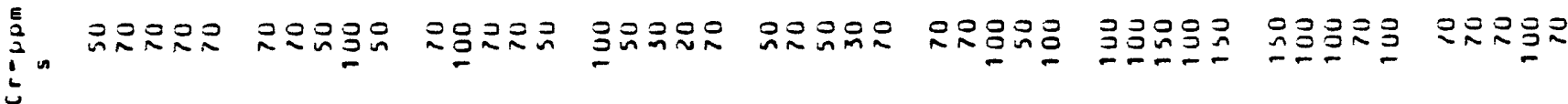

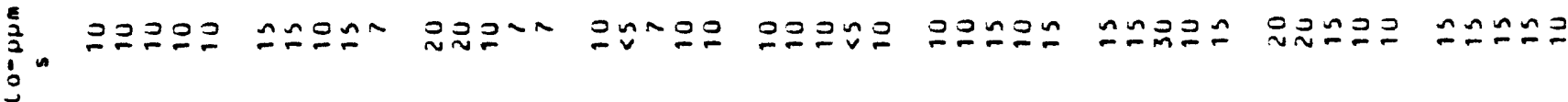

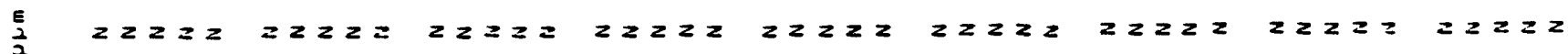
3

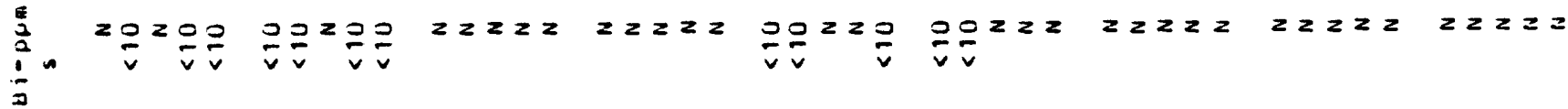
ق̆

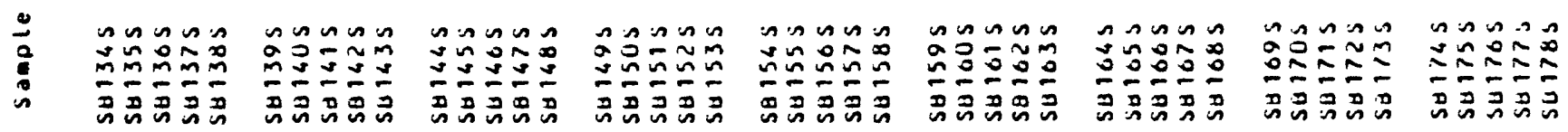


厑:

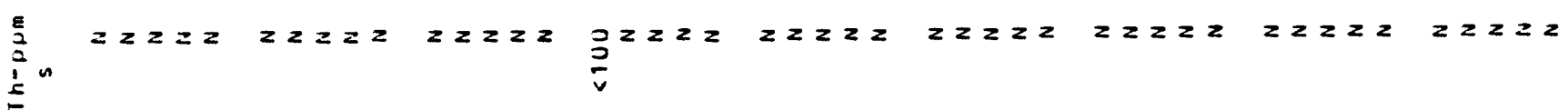

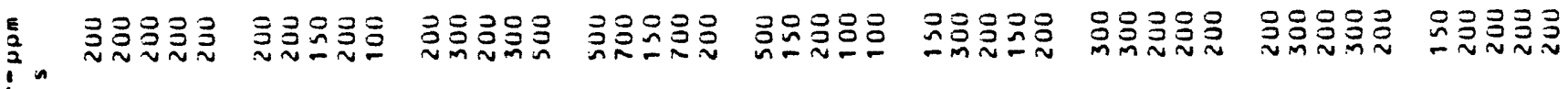

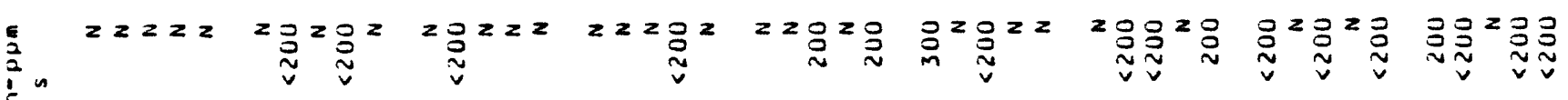
$\stackrel{s}{s}$

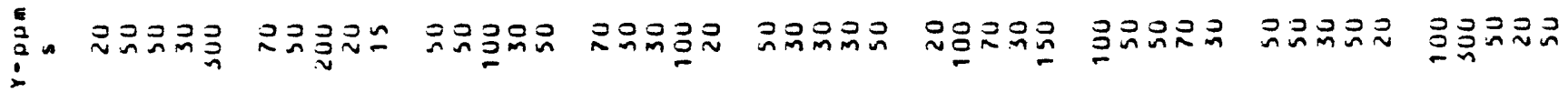

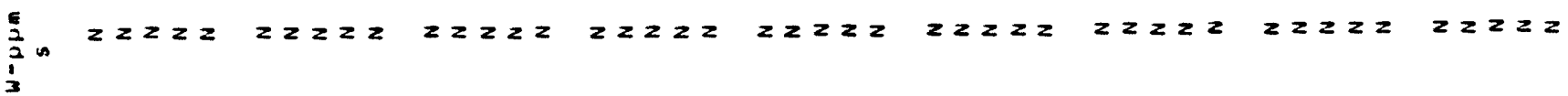

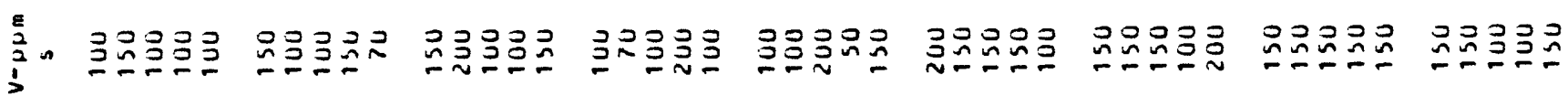

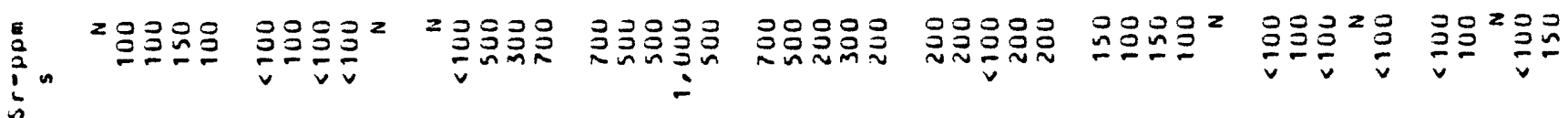

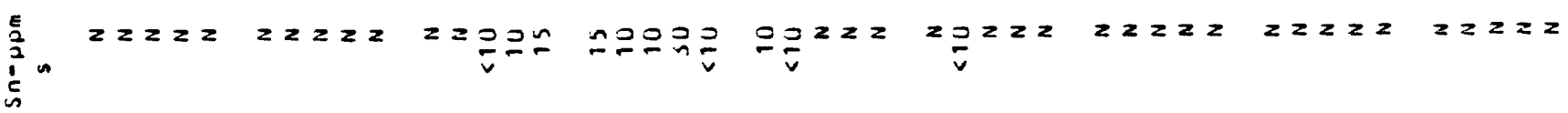
ดีดกุ

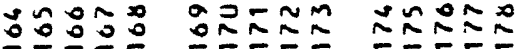

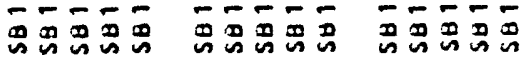




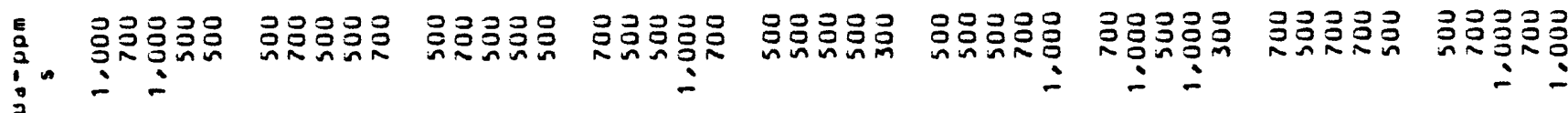

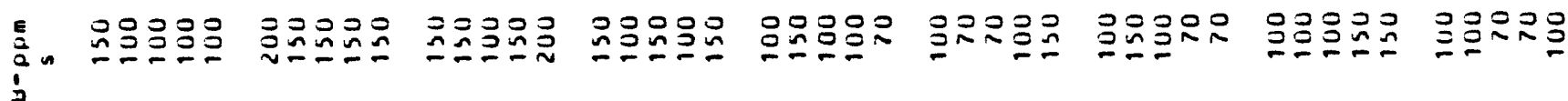

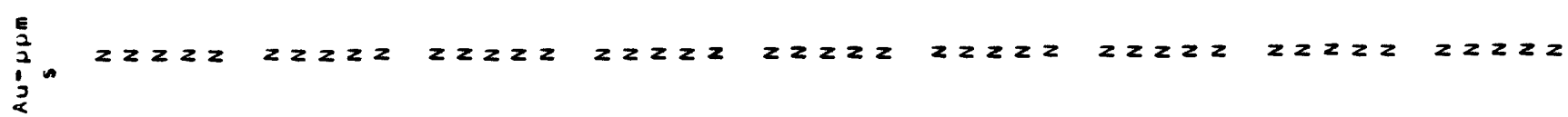

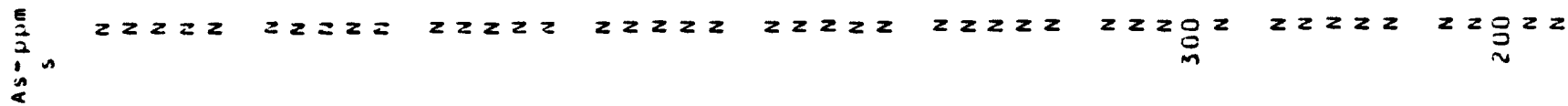

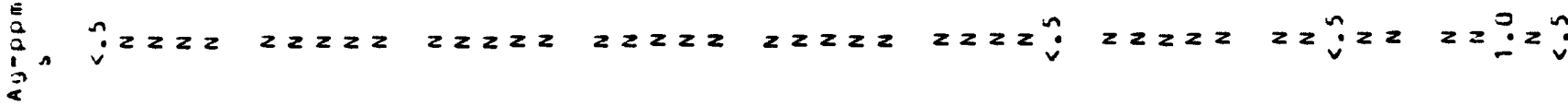

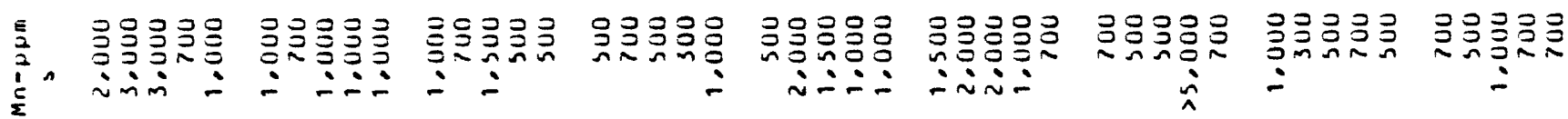

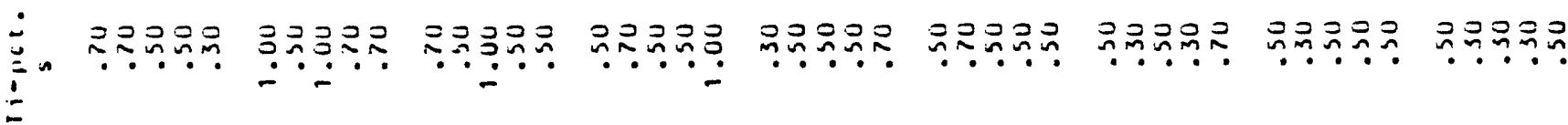

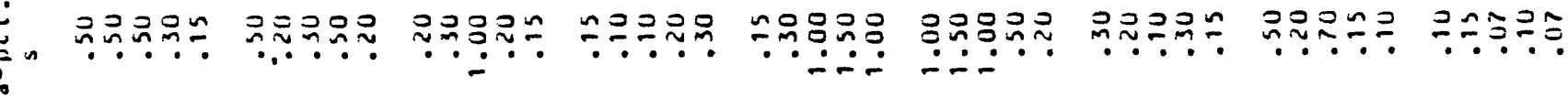
is

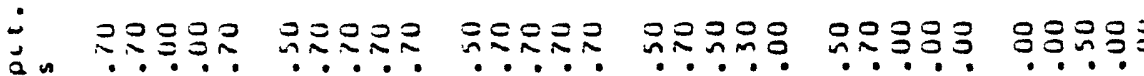
iñ ก N-. -

옹ํำ

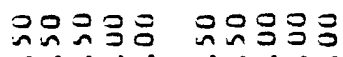
宝 $\vdots$
$\vdots$
$\vdots$
$\vdots$
$\vdots$
3
3
3
3
3
3

jos 00000000

p0000 00000 00000

0000000000

00000

00000 opopos

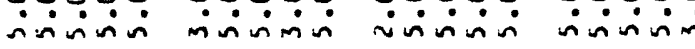
حivión

in

\section{asinas}

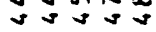

ำํำ

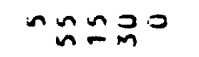

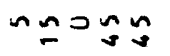

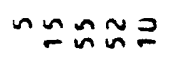

กีก류

กีวุที่

织娄斗品

只星的品品

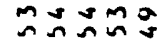

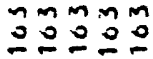

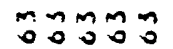

ตุตm?

in $\operatorname{in} 500$

部的识品

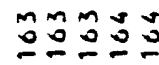

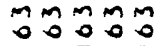

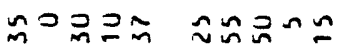

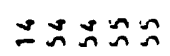

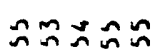

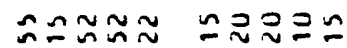

$\pi$

กกกว

วณที่ก

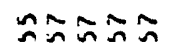

in- - D

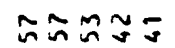

ラこここう

की

र.

व.o.

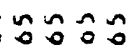

o.

.0.0.0.

นกำก์

Pํำว

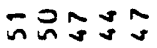

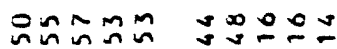
ตำำ.

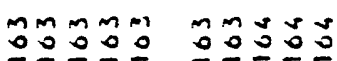

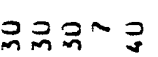

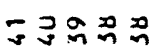

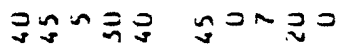

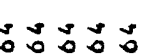

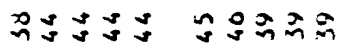

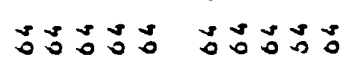

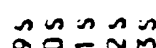

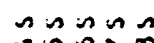

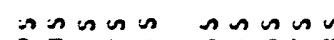

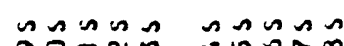

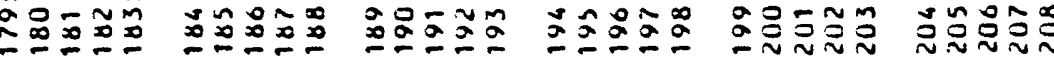

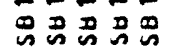

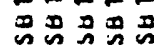

คิธ

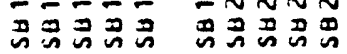

号药虽品思

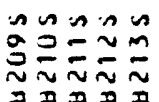

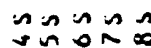
$\bar{\sim} \approx \bar{\sim} \frac{\infty}{\sim}$

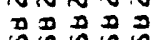

กินกำ $-\tilde{\sim} \approx \approx \sim ⿻ 上 丨$

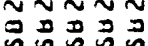




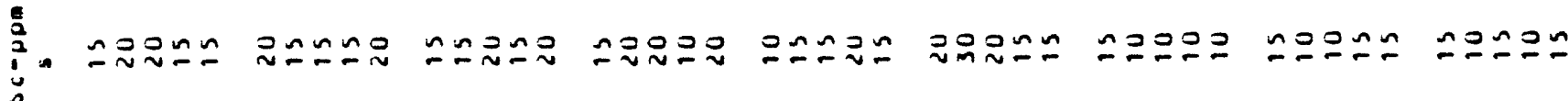

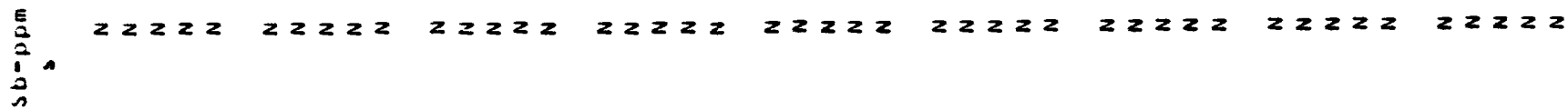

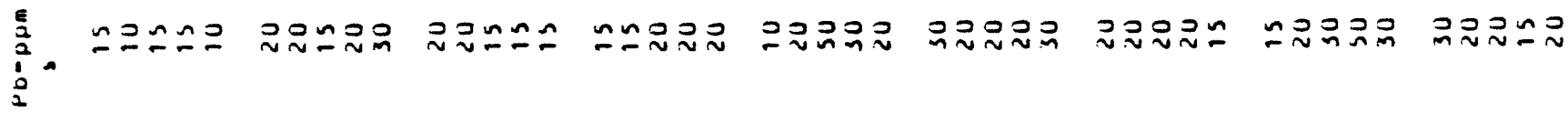

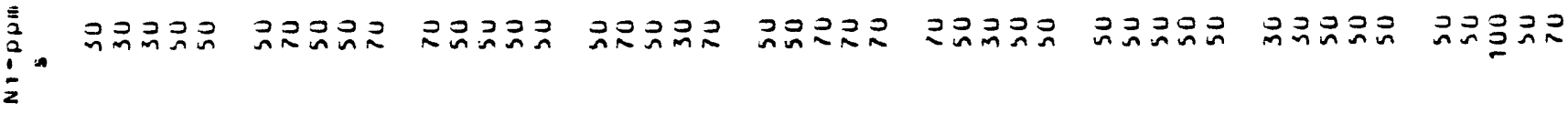

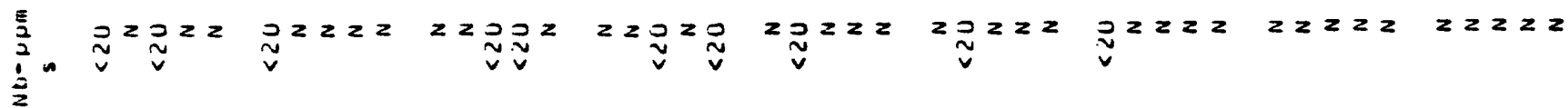

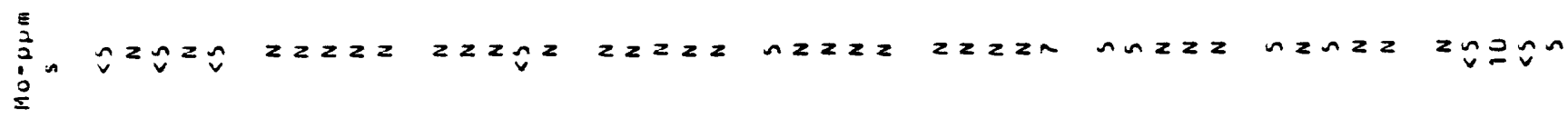

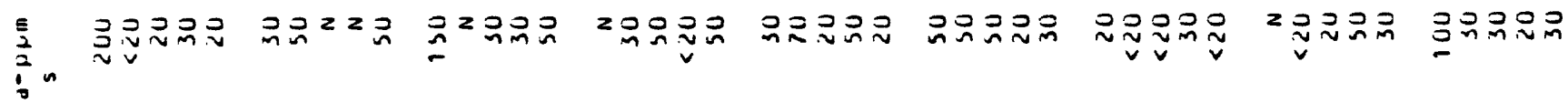

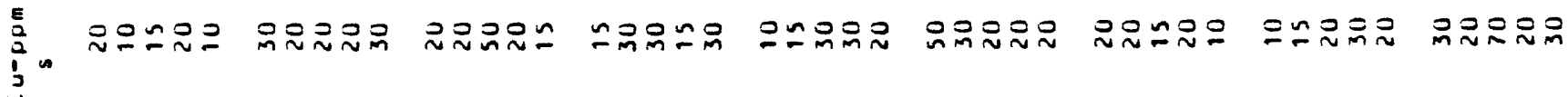

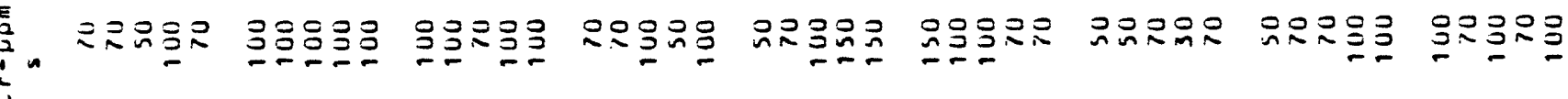

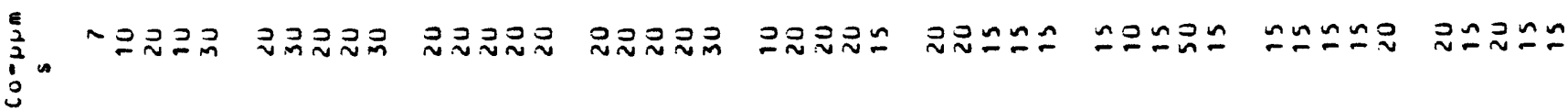

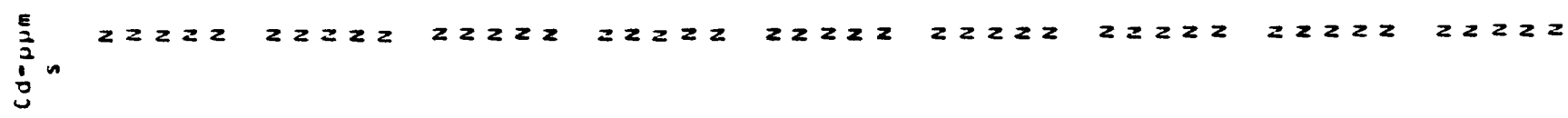

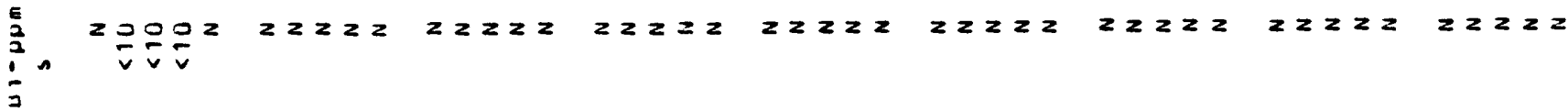
章

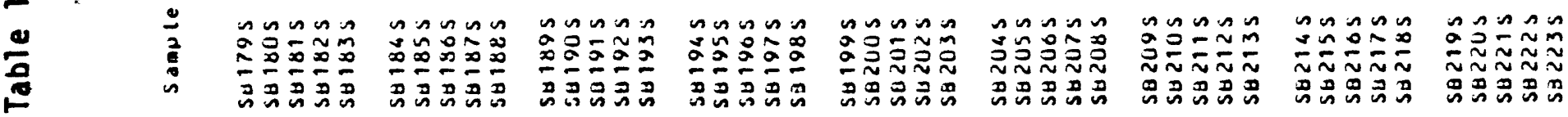




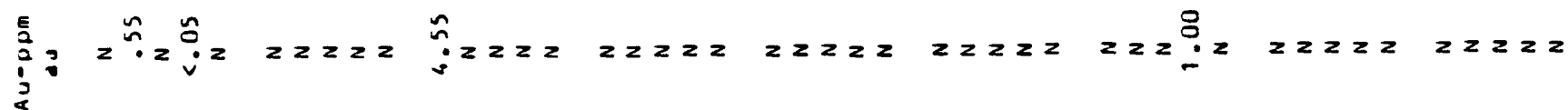
$\stackrel{\Sigma}{\stackrel{\Sigma}{\partial}}$

$z z z z 2 z z z$

$z z z 2 z z 2 z$

$2 \geq 222$

$z=2 z$

$z z 2 z=2 z 2 z \quad 2 z 2 z 2$

$\stackrel{\frac{E}{2}}{2}$

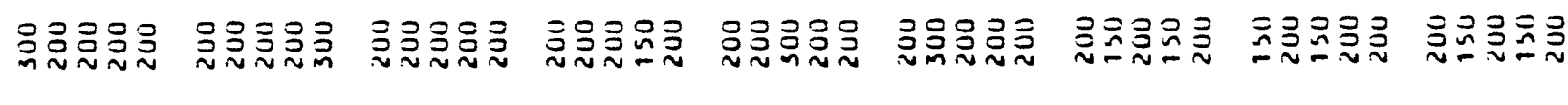

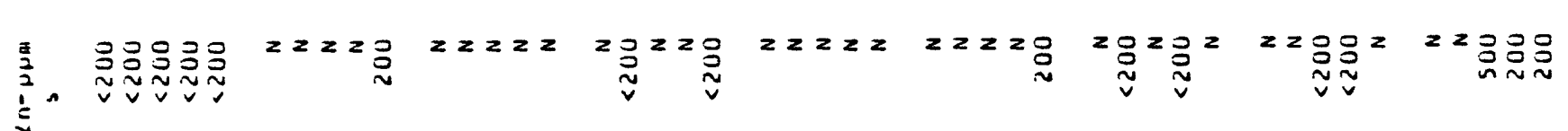

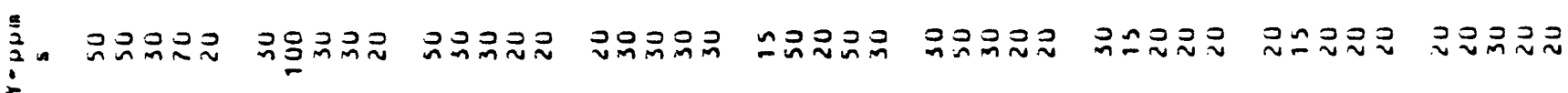

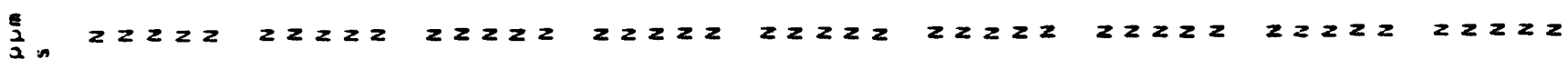
3

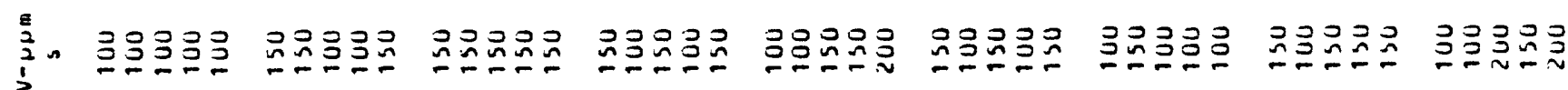

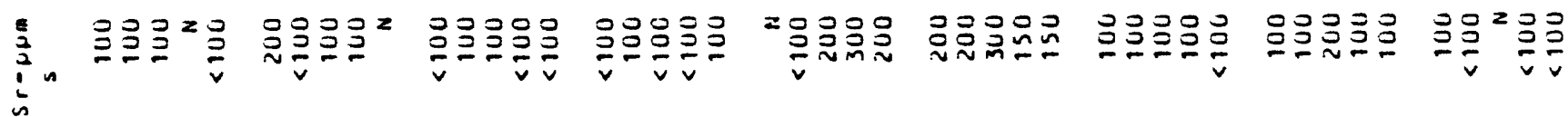

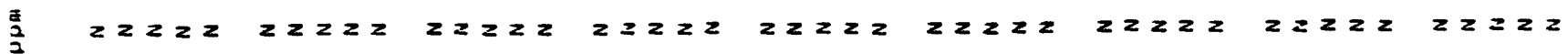
$i^{2}$

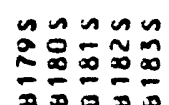

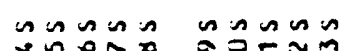

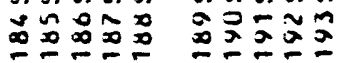

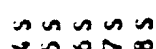

ำลำํํำ

ก ค n n n

을돌

แnก⿻上丨 nun

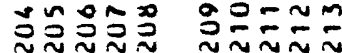

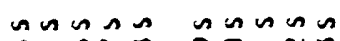
焉品焉 


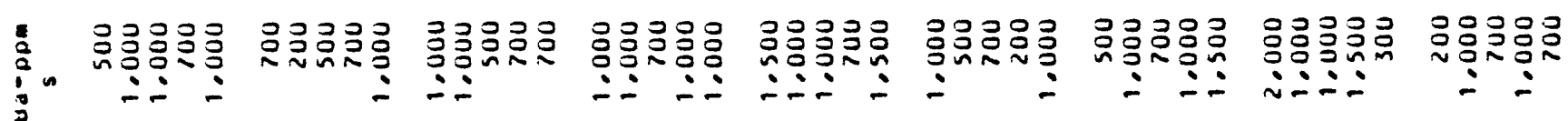

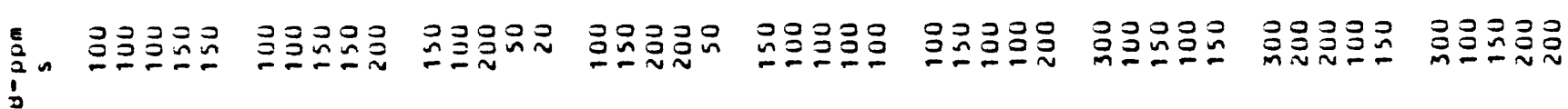

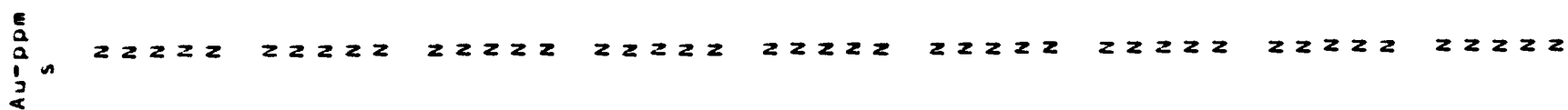

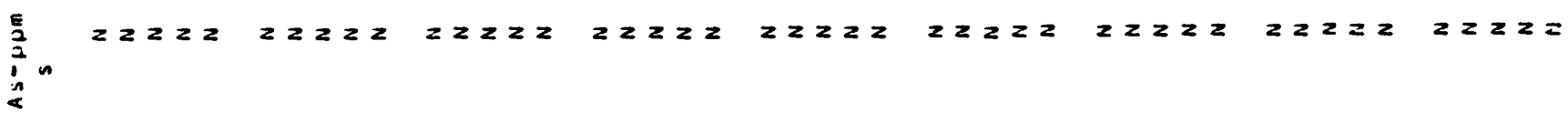

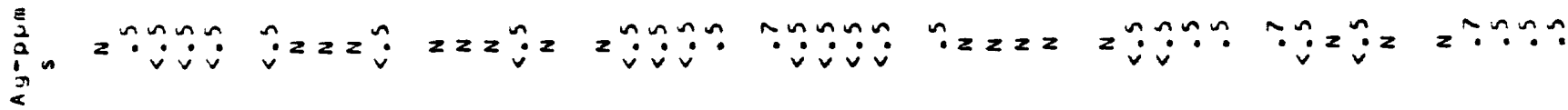

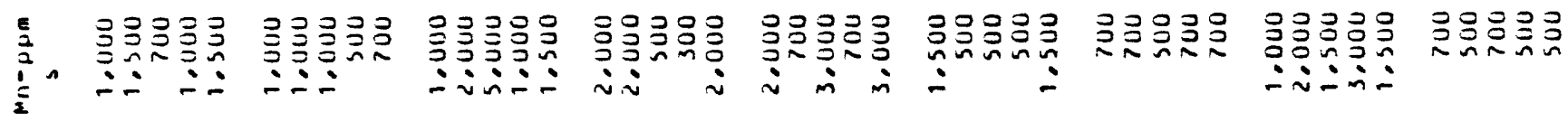

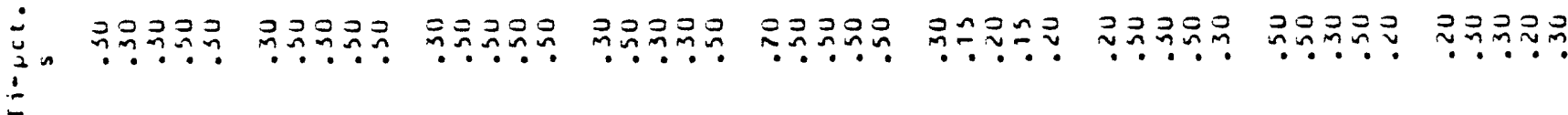

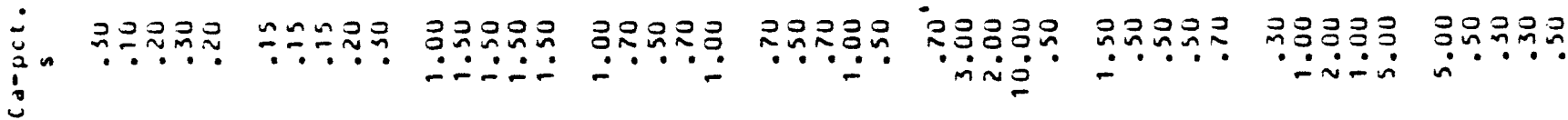

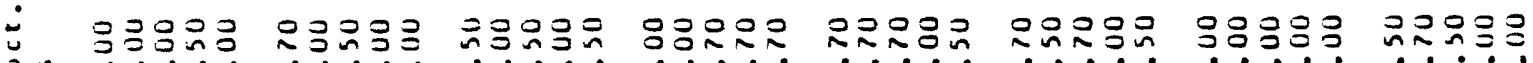

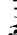

00000 00000 00000 00000 00000

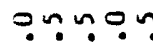
ก?:?․ำ ก0?0?

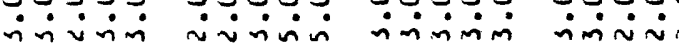
$\sim \sim \sim \sim \sim$

$\sim-\cdots$ $-\sim \sim \sim \sim$ - $\sim \sim \sim \sim$

응융요 ……

ำง

maIE= EnะNE

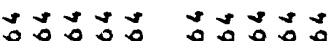

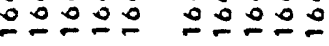

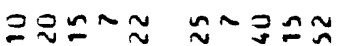

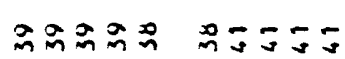

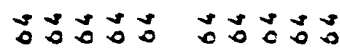

\section{m}

싱

$\sin \backsim n$

ํํํํำ

กำกำ

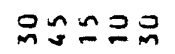

은ำ

วนก๊ำ

管

MMก $\sim \sim ⿻$

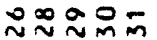

nलmm

mmmm

ํำ

mm m

ํํํํำำ

$\because 0 \div \div \div$

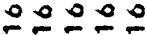

은은

กำำำ

$\sim \sim a=a$

DoD 0 ก

$\supseteq \simeq \simeq \simeq \simeq$

ะㅡㅇ

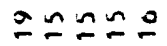

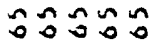

$\hat{0} \hat{0}: 0 \hat{0}$

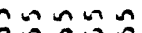

0.0.00
ว ํํำ的思

mmmm

$\therefore \div \div 00$

그ํํํํำำำ

$\simeq \because 20 \approx$

nก⿻上丨

ค0:000
马อง

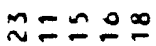
mpmp?

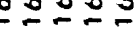

o ํํำ 이르

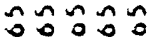

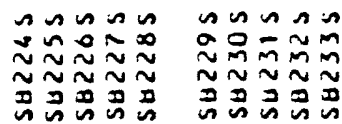

in $\sin n \sin$ กnคn unun

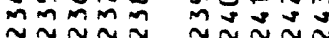

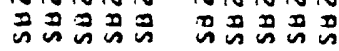

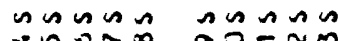

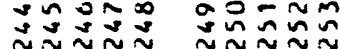

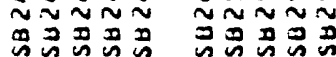

$\sin n n$ ถัก๊ำกำ $\sim \approx \approx \sim \approx$

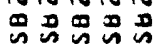

กินกี

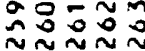

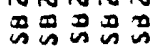

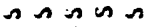
ชงกง กี⿻

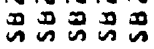




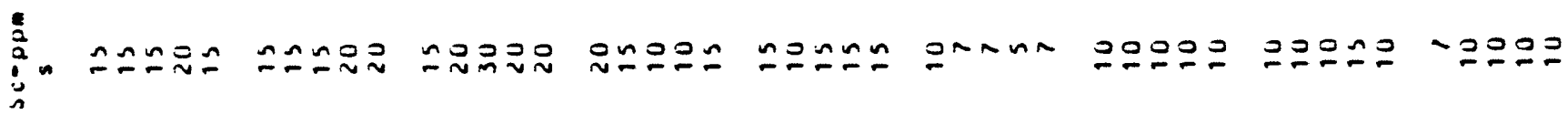

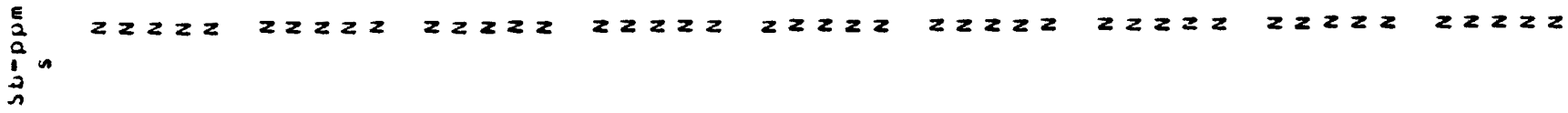

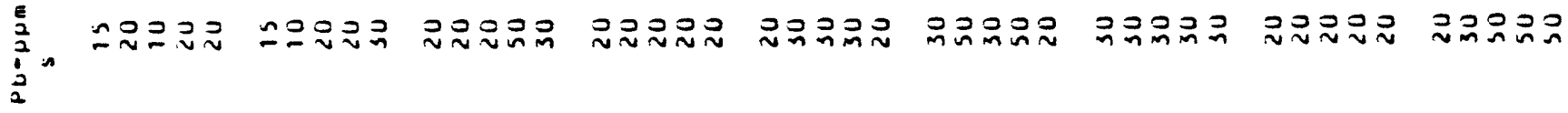

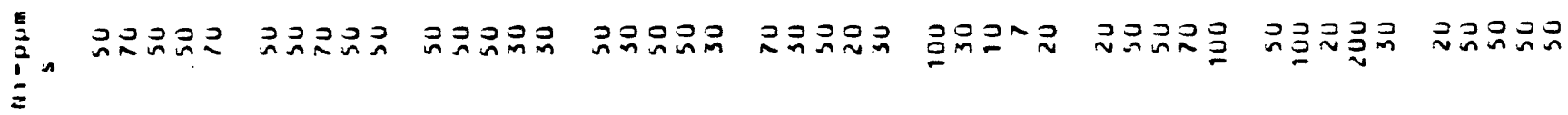

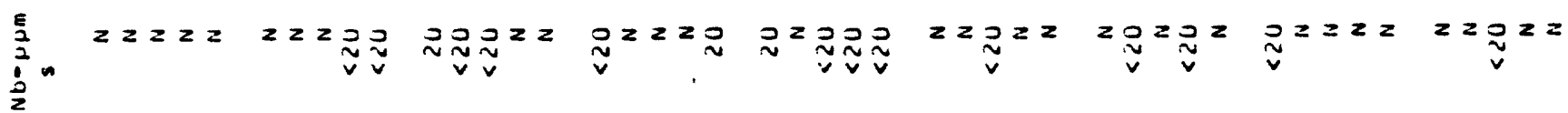

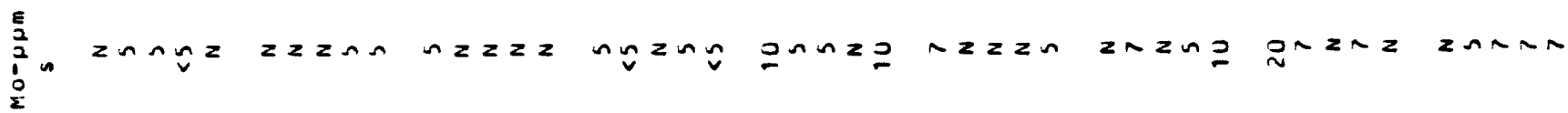

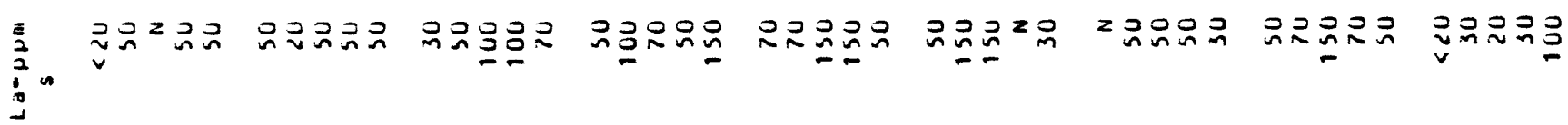

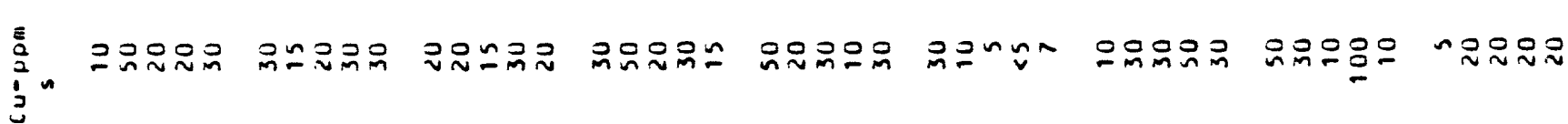

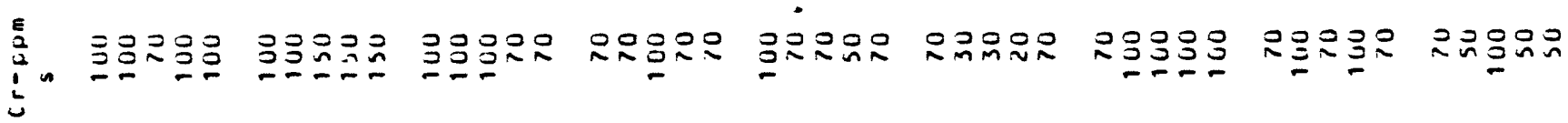

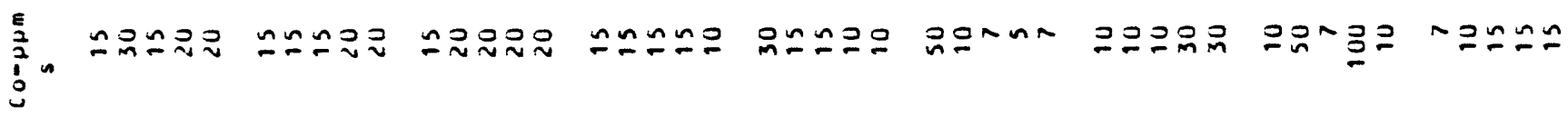
1.

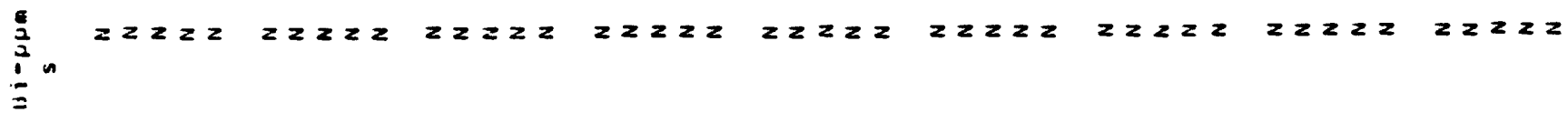

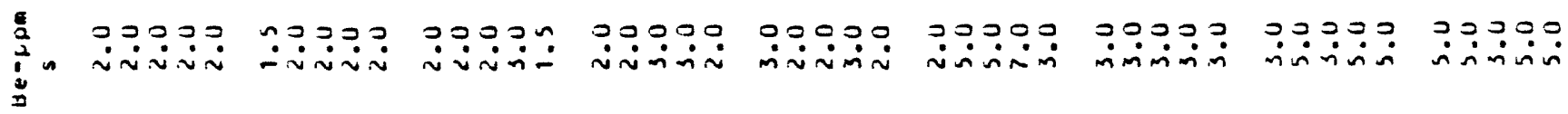

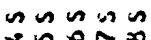
ำำํำ 
焉:

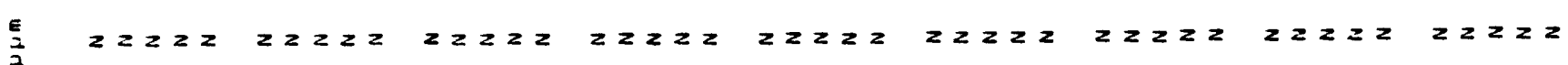
$\stackrel{2}{E}$

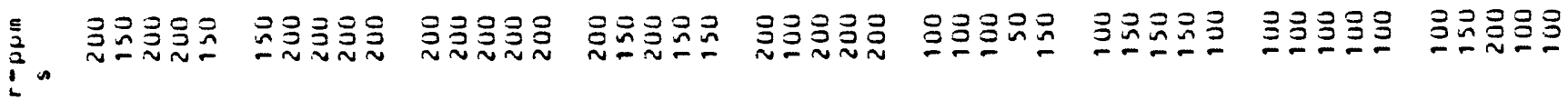

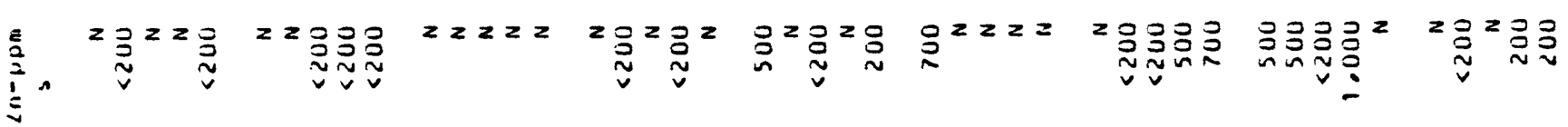

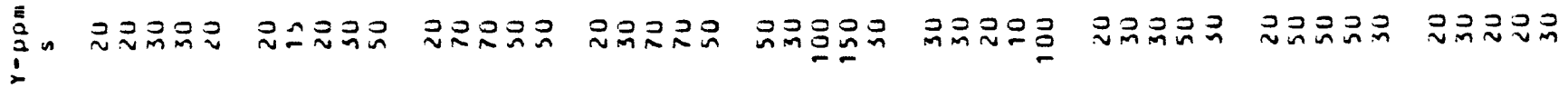

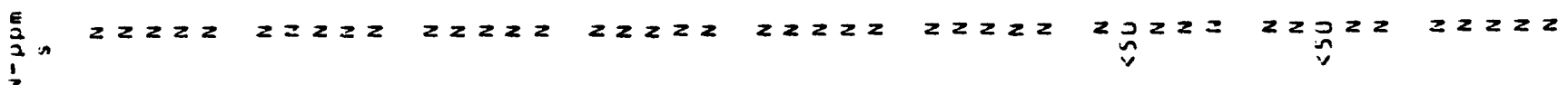

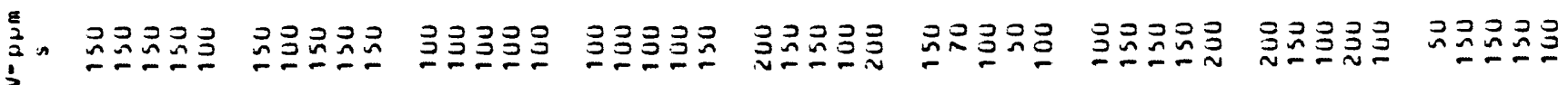

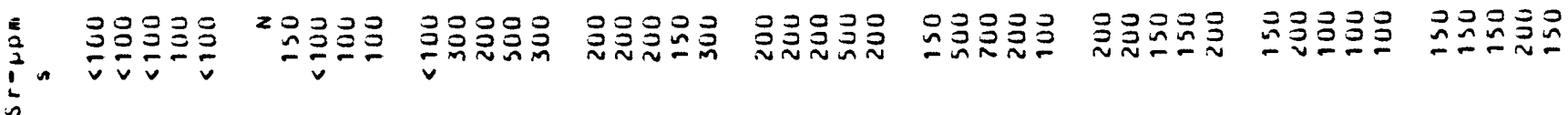

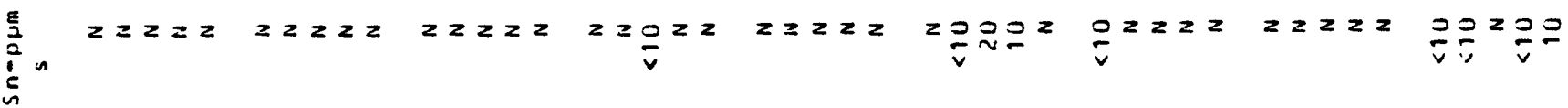

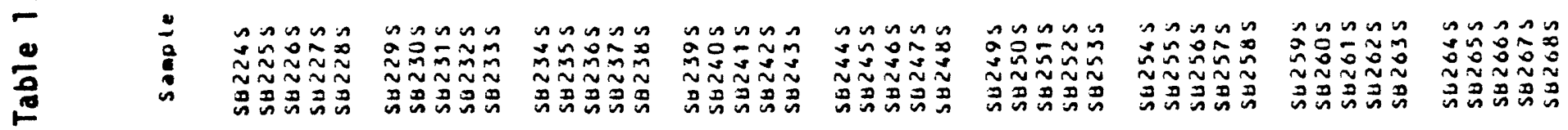




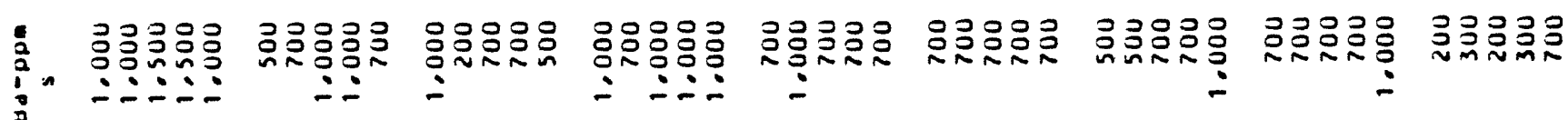

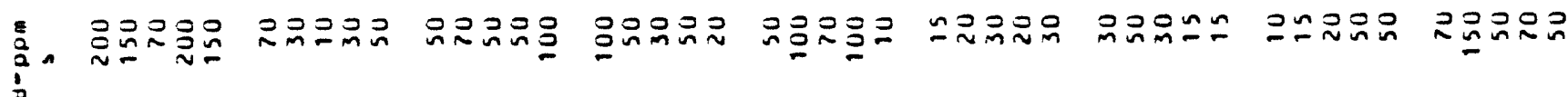

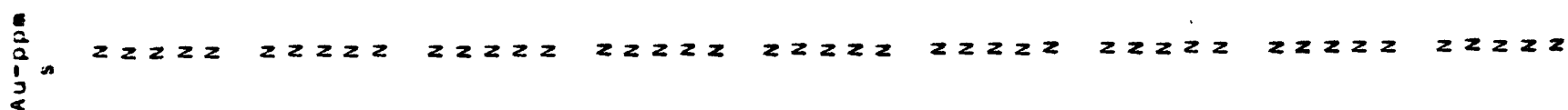

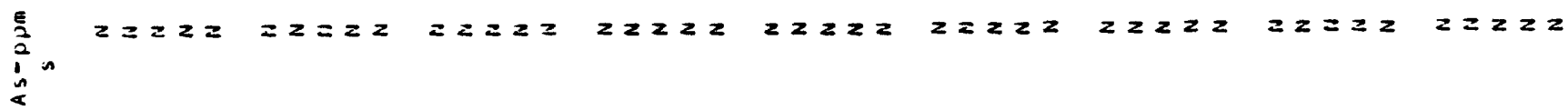

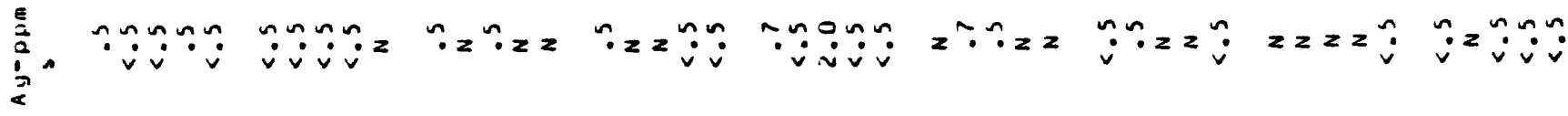

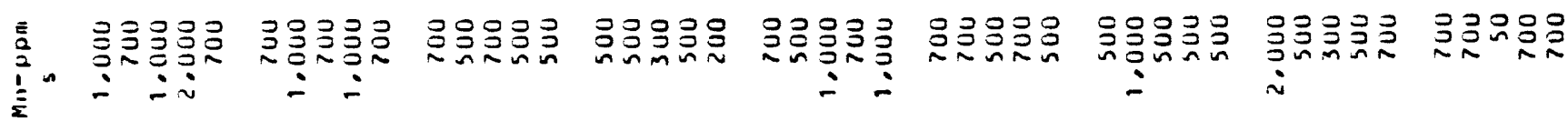

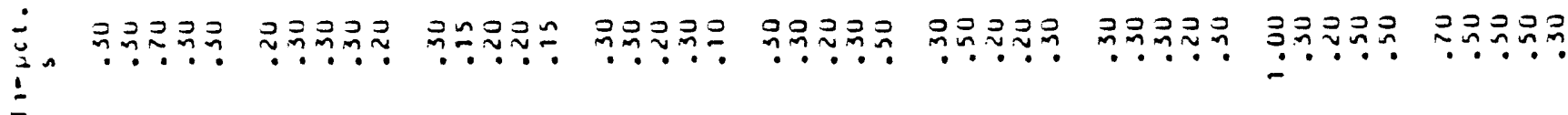

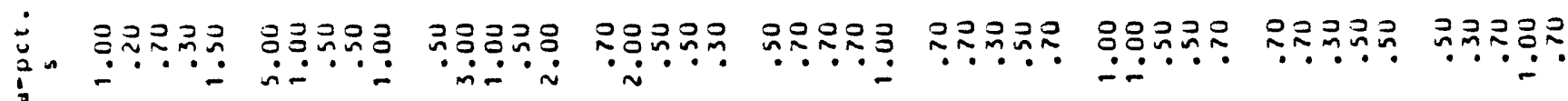

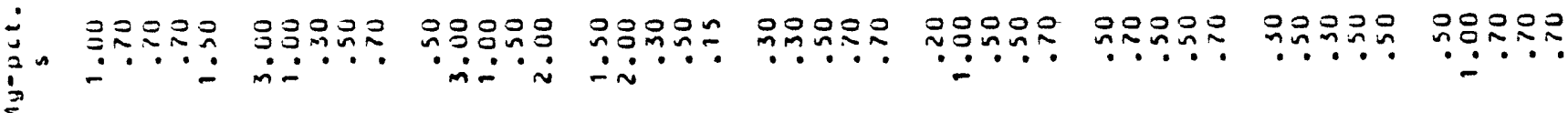

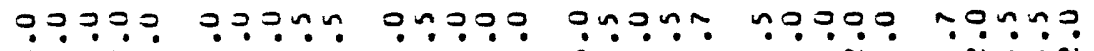

?ด:? onคoㅇ 00000

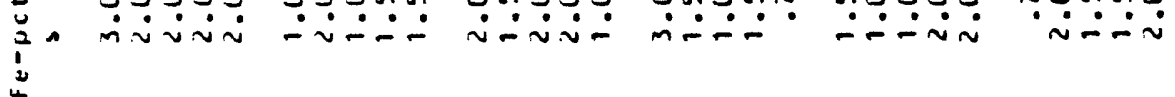

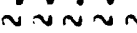
$\dot{\sim} \dot{\sim} \dot{\sim}$ inimin

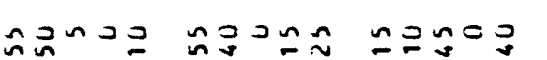

Doning

윰ำ

nova

$a \simeq 0 \infty=$

$=\sim \backsim \sim a$

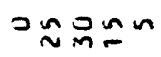

ำกำ Nnging

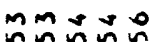

ํำ:ำ

mmnm

MMmmm

mmmn

ํํํํํำ

$\sim \sim \sim \sim \sim$

๑๐ำ

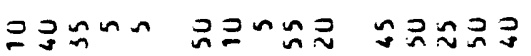

ก马รจะก

กะวูอด

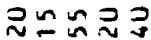

$\supseteq \simeq \simeq ニ ニ$

$\pm \stackrel{0}{-1}$

$\simeq ニ ュ ュ \cong$

$\simeq \supseteq \simeq \simeq \cong$

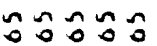

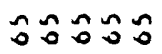

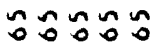

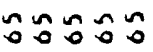

$=a \div \div$

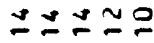

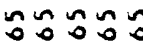

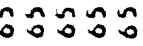

คำง

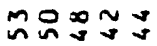

ก $\sim \sim \sim$

으은

กุะอกะ

- $09 \simeq \simeq$

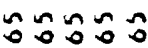

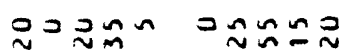

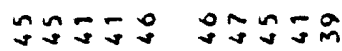
บํํำ

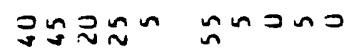

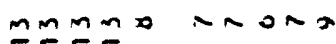

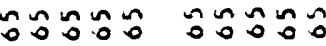

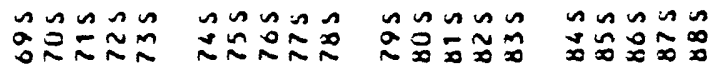

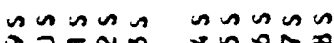

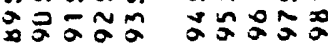
$\sim \sim \sim \sim$ 品蛋品品

คี

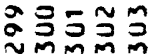

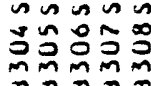

in in $\hat{n} \hat{m}$

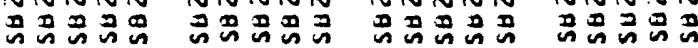




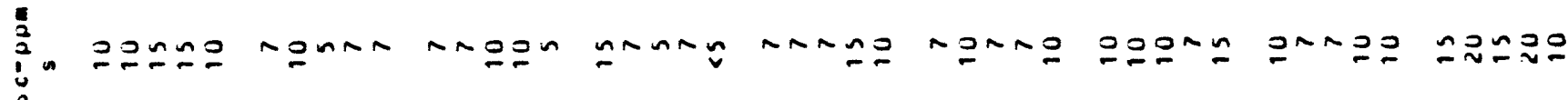
$E$
$\frac{1}{2}$
$:$

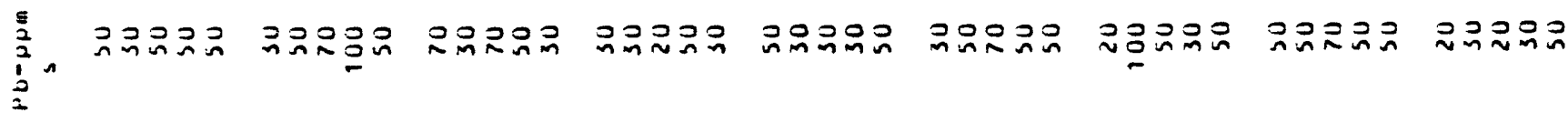

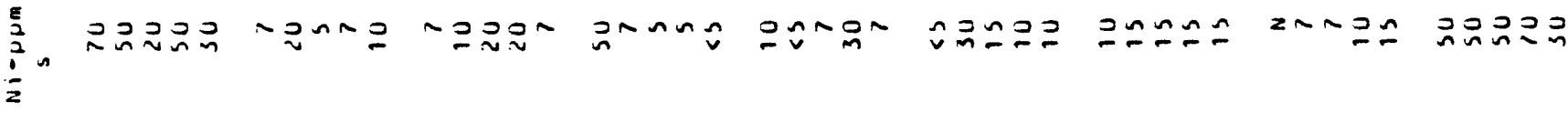

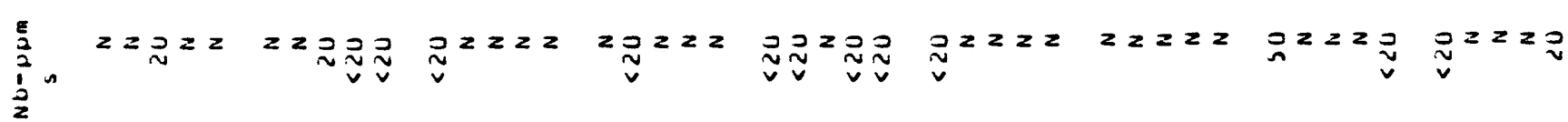

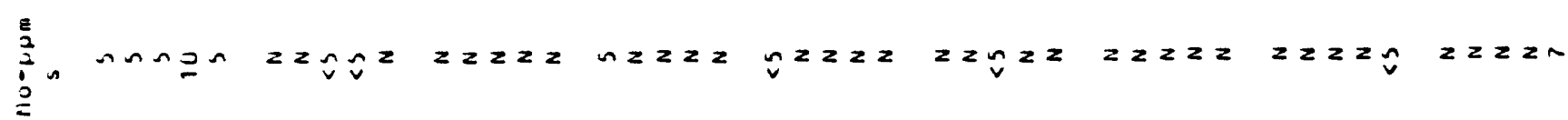

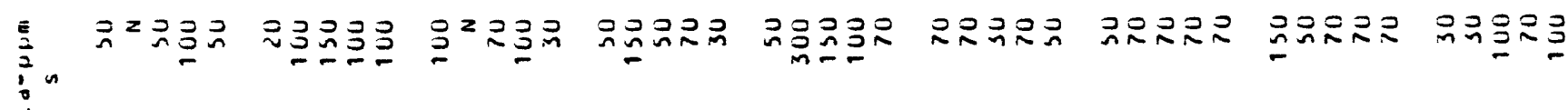

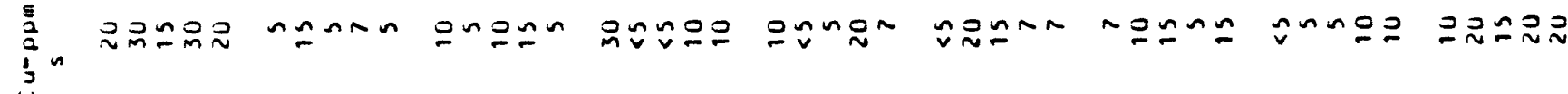

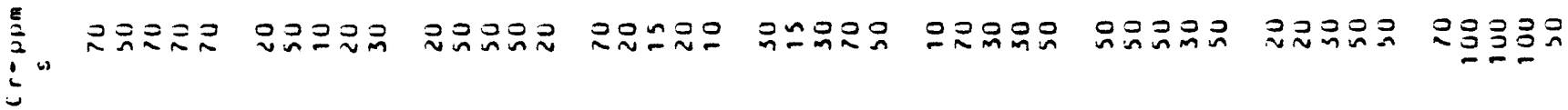

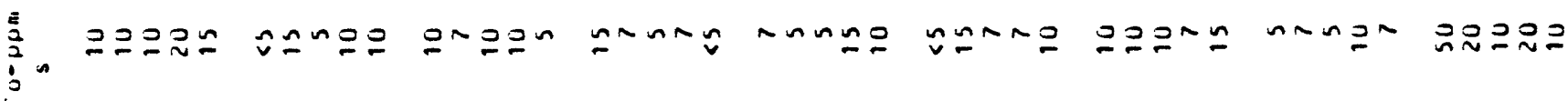

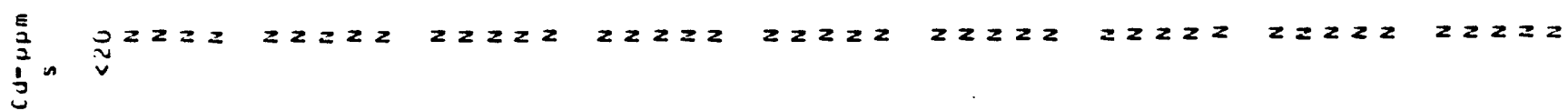

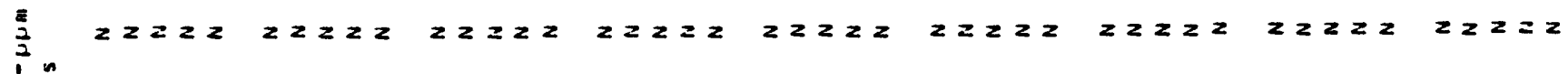
$\frac{1}{1}$ $\frac{E}{2}$
$\vdots$
$\vdots$
$\vdots$

วつつつว

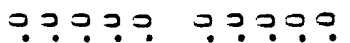

$? ?: ? ?$

ว? ?? ?

วองวอ

ด? ?:?

๑??? ??:??

in $\sin$

ninin

กับที่

ninis

ñinis

Nininis

inimi

inini

in vin

คnด n

กิดก

NNNN $\tilde{N} \tilde{N} \tilde{N} \tilde{N}$

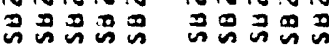

$\sim$ กิน

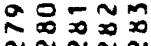
$\infty \infty$

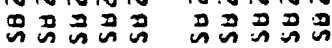

ñ $\sim \sim n$

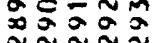
$\sim \sim N \sim N$

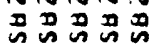

$\because \backsim \sim n n$ $\sim \sim \sim \sim ⿻$

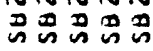

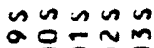
虽品虽品 品品品品只

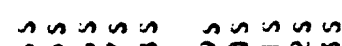

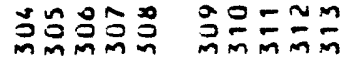

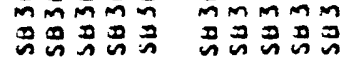


镸:

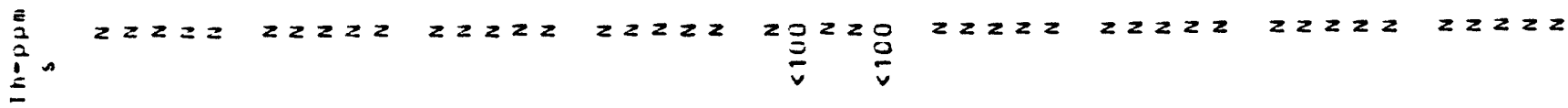

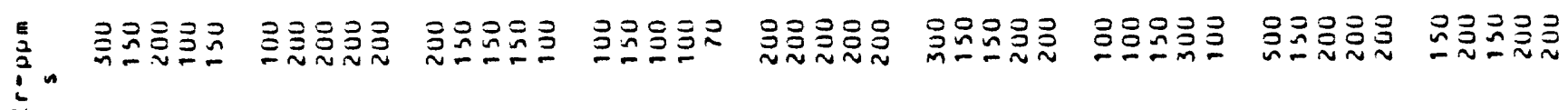

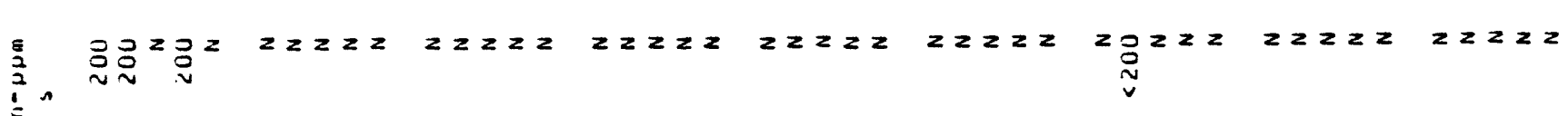

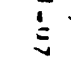

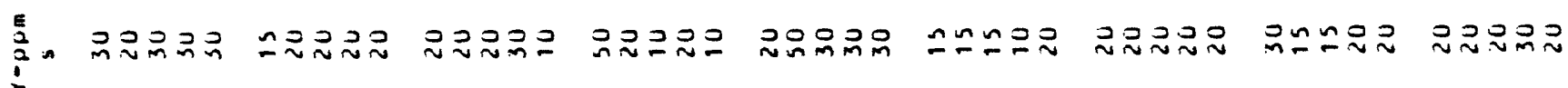

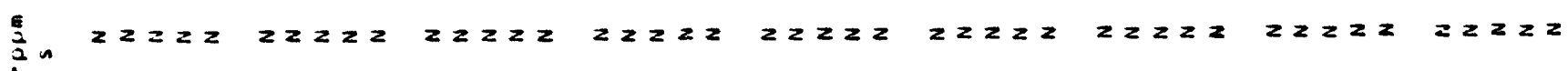

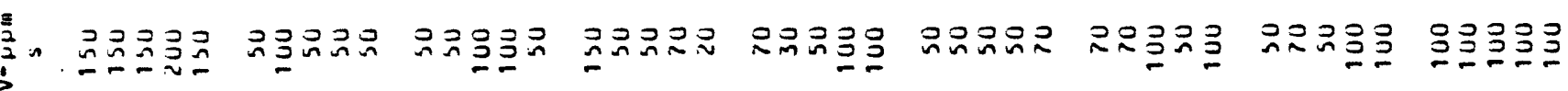

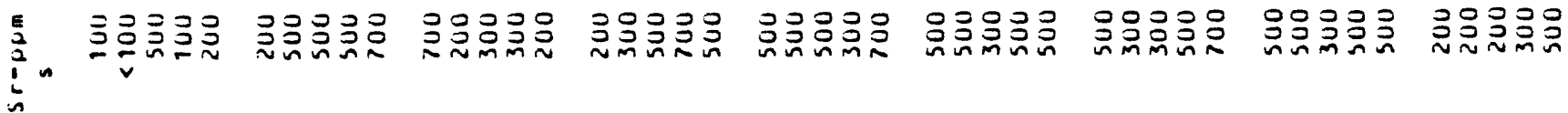

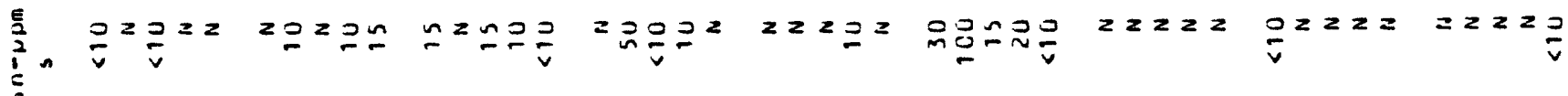




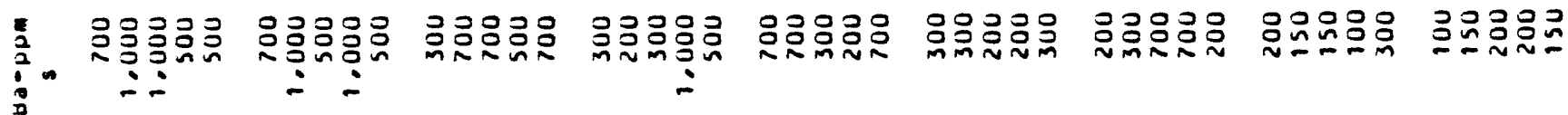

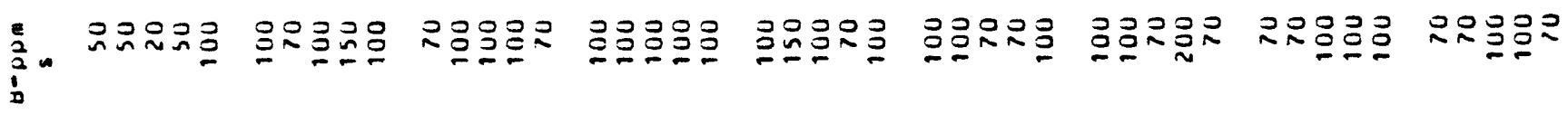
迸

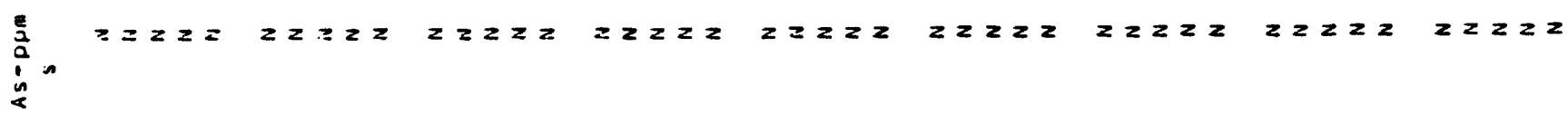

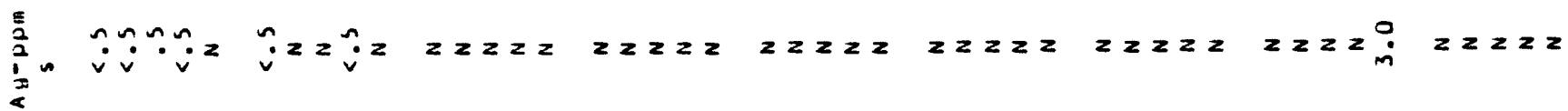

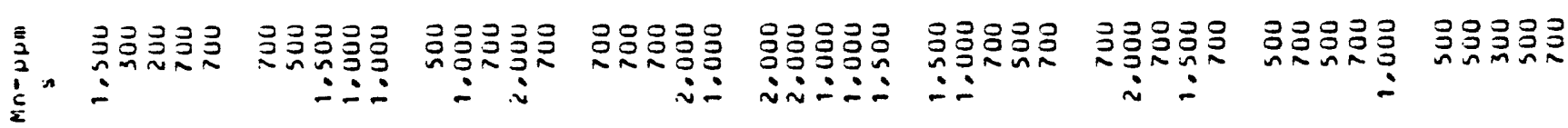

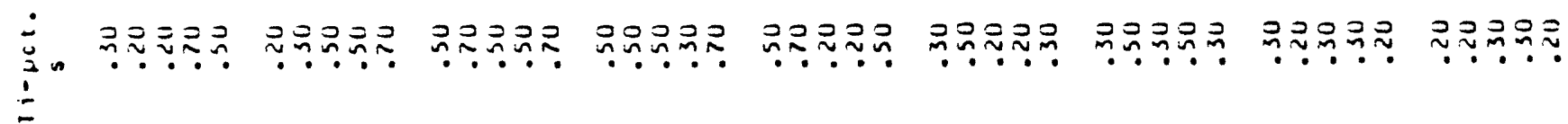
$\vdots$

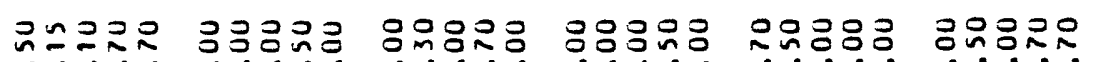

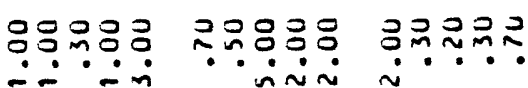
$\therefore \because \therefore$ i ini $\dot{n} \because$ $\therefore \because n$

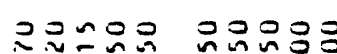

$\because \ddot{\sim} \dot{0}$

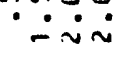

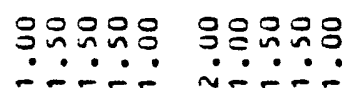

n- -

ongop

$\ddot{m} \ddot{0} \dot{0} \dot{\sim} \dot{\sim}$

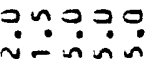

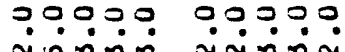

inisin

iिं

90900 ñmin

คinimin

$\therefore \geq$

:ำ?

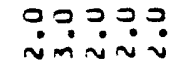

จงคำ

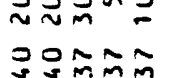

르ำงำ

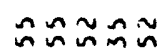

곡ํำำ

กับกี⿻ำ

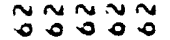

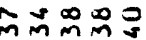

站的的的

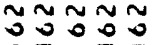

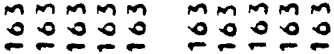

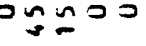

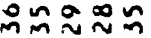

ติำำ?

m̃D兄

กับ

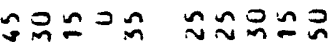

$\alpha \geq \simeq 00$ ondon

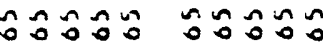

ปกำำ

ooonn

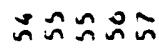

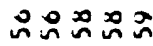

npon

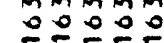

र.

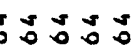

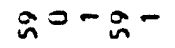

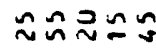

一盆会出的

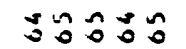

की.
กำก

シニロニニ

ตำ?

$\approx \tilde{\sim} \approx \approx 0$

的总冷焉

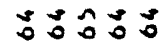

DONN

믚

mmмnm 응ㅇㅇㅇㅇㅇ

호올

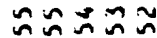
จ.
ํำำรว $=\infty, \infty$ 응 mMnm

๓ก๊จฏอ กำ品品向

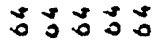
요요

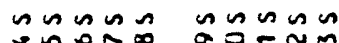

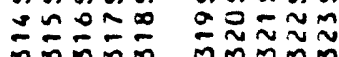

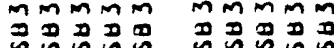

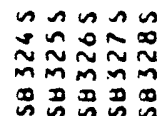

ns⿱ $⿻ 心 ㇒$

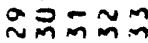

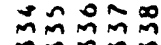

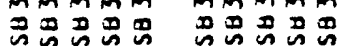

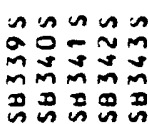

nก $n$ ก

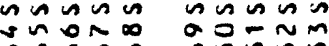

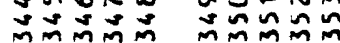

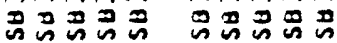

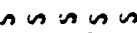

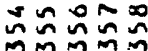

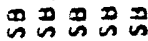




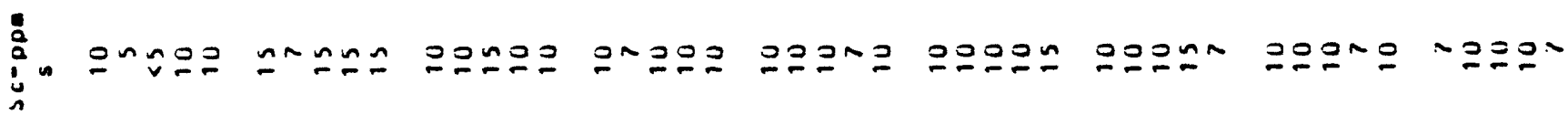

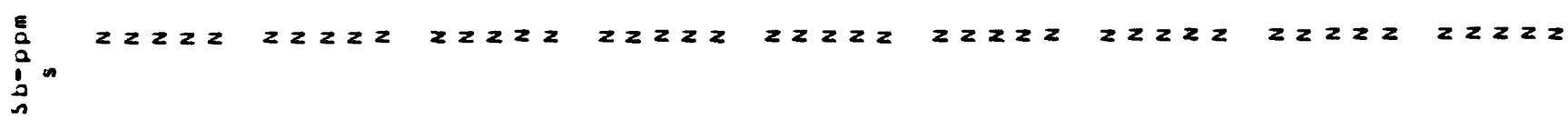

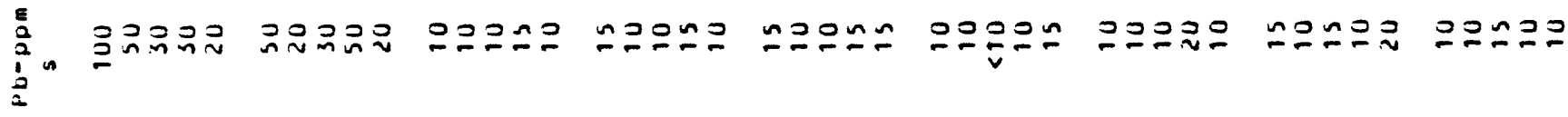

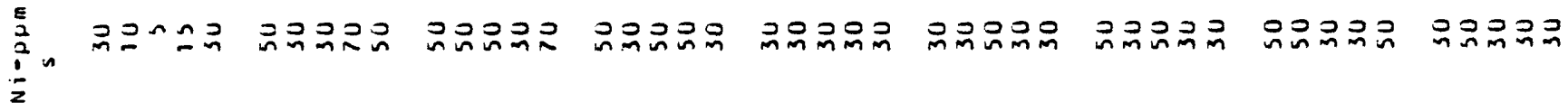

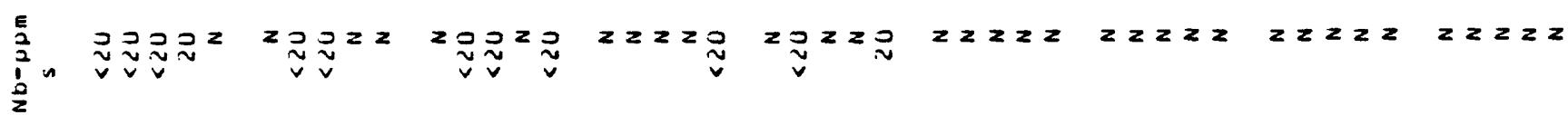

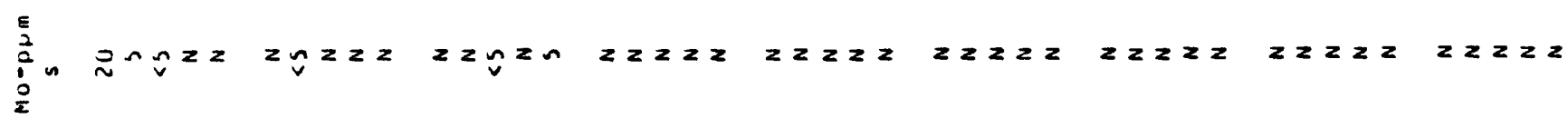

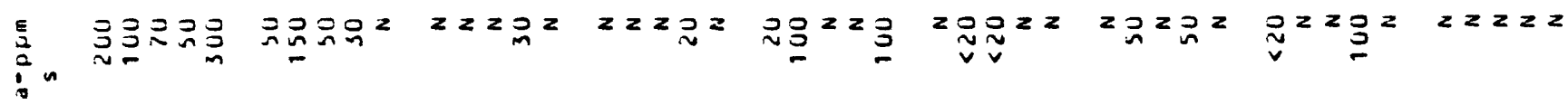
is

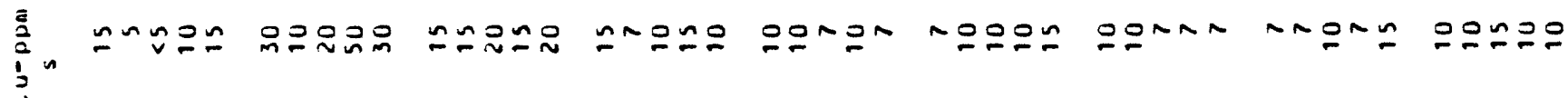

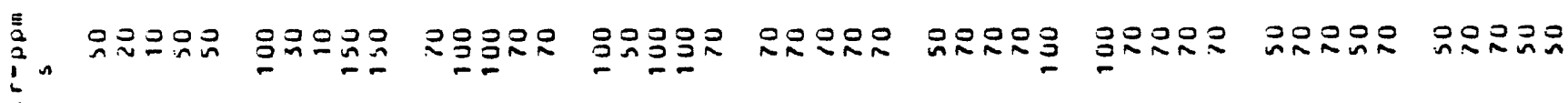

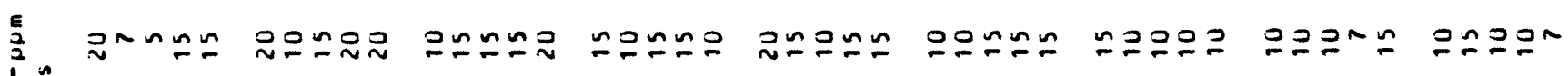
$\dot{0}$

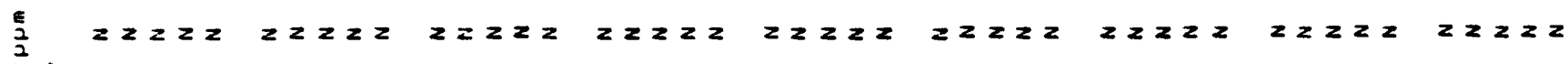
$\dot{j}^{\prime}$

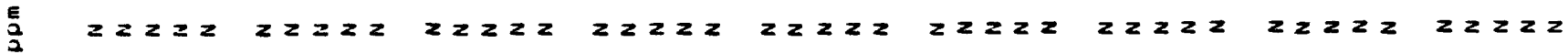
$i^{2}$

年

多

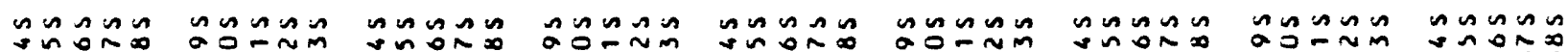

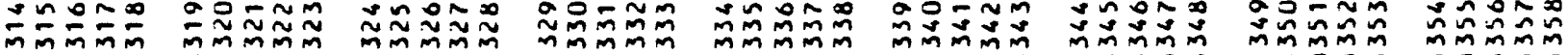

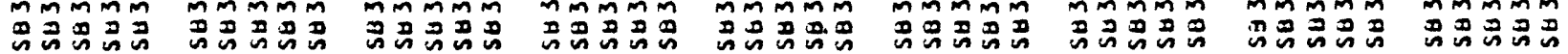




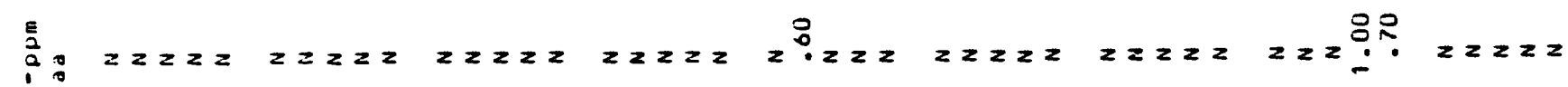
3

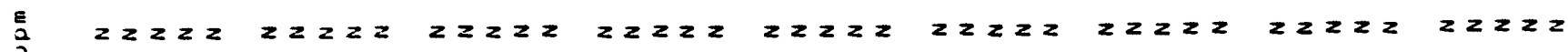
$\stackrel{1}{2}^{2}$

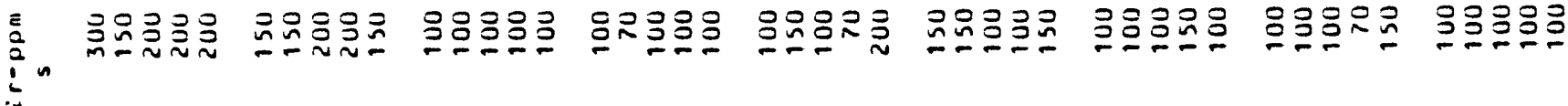

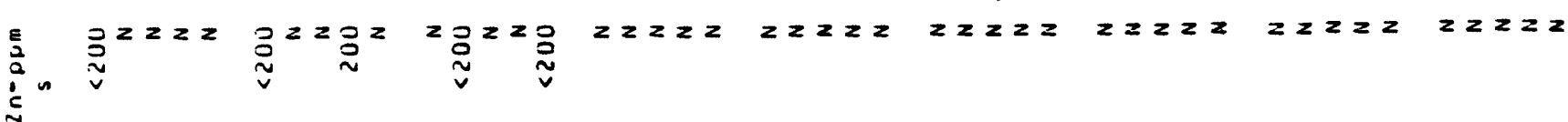

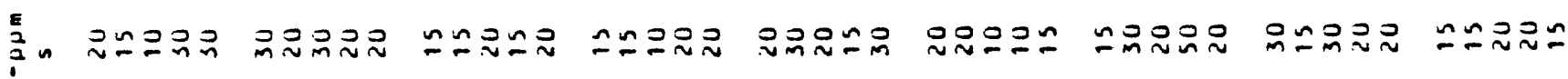

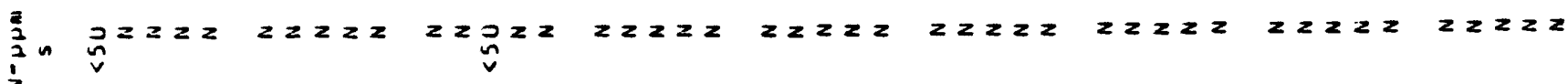

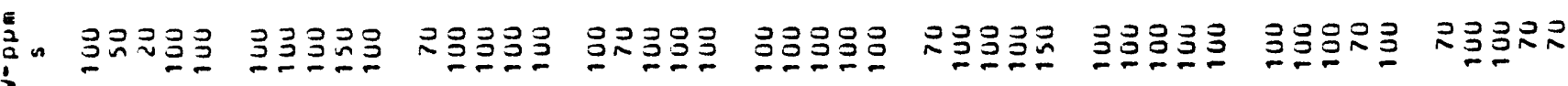

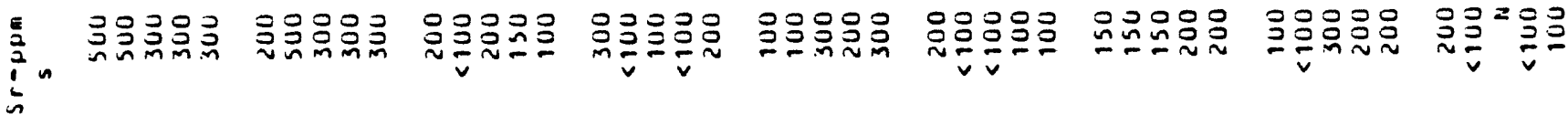
焉 is 


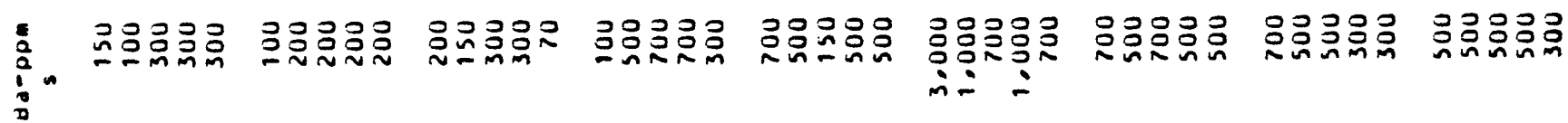

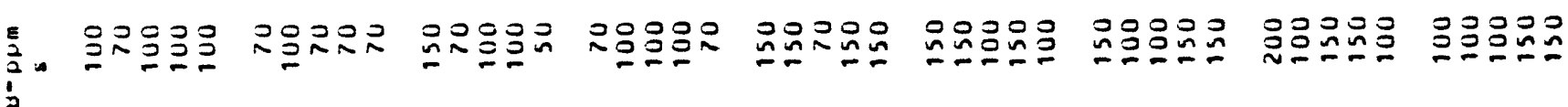

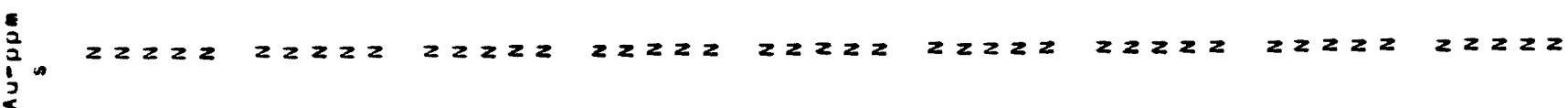

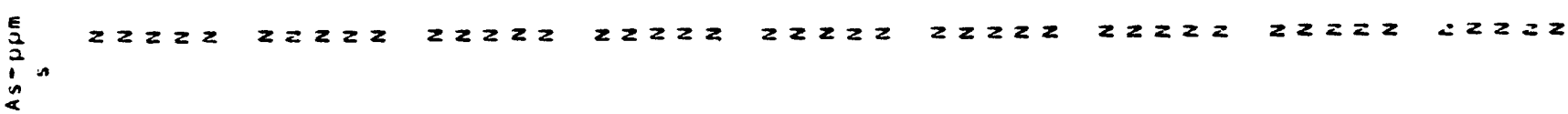

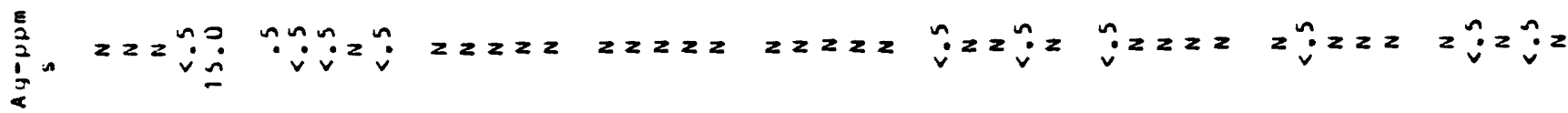

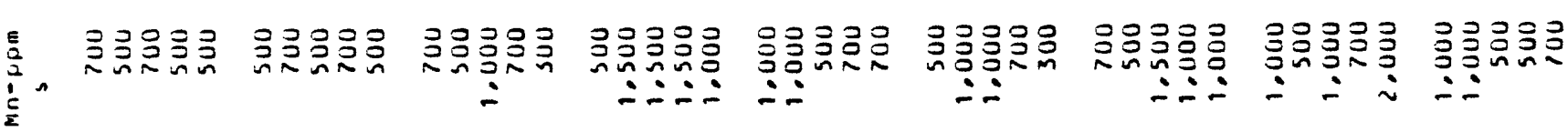

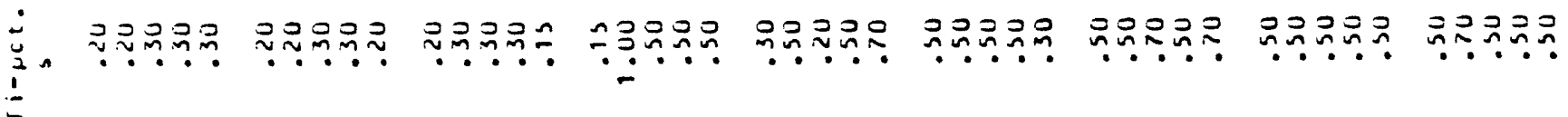

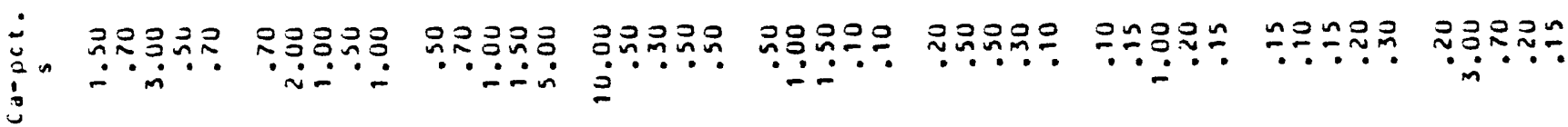

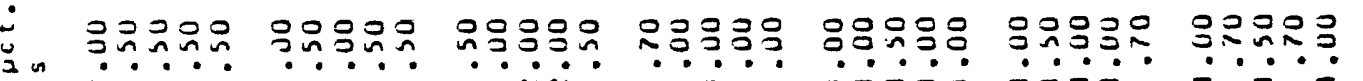

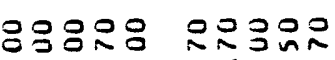

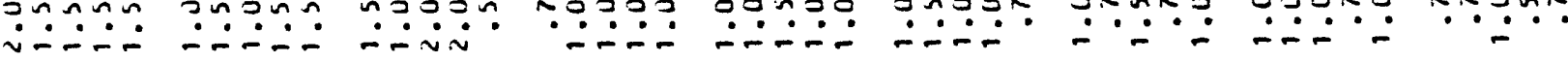
is

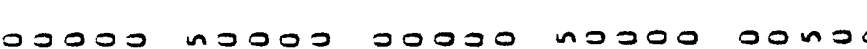

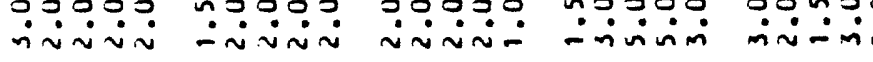

00000

$0.0 .0 ?$

?.0.0? ?:000? $\dot{u}_{2}^{\vdots}$ $(20)$

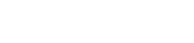

$\operatorname{nnn} 2 \pi n$ 고ำํำํำ

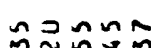
Dogñn ongำ ing gog m

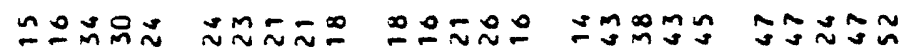

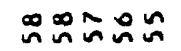

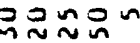

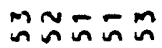

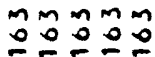
MmMMm MMMMm mmmmm mmmmm mmmm mmmmm

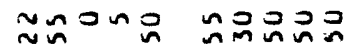
inam $\infty$ ina

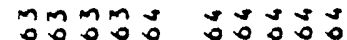
ㅇำำ nnon ํำำ $\div 0 \div \div \div$ ํํ은

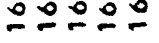
ํํำ ํํำ ำㅇำ ะกนกำ

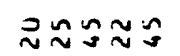
๑ㅙำ

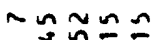
그음ㅇํㄱㅡㅡ गु:

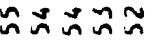

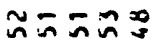

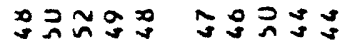

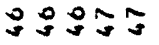
象密各事的

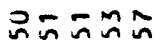

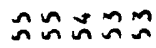

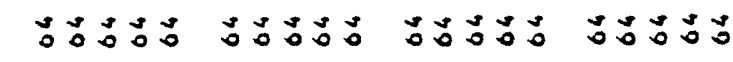
यु. i.jog.jo

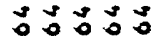

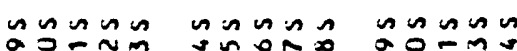

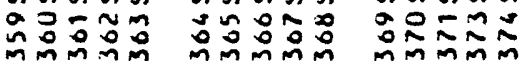
跑品召思

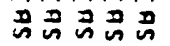

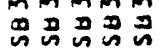

n๐n กิำกำ

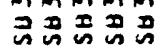

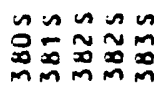

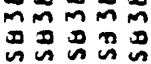

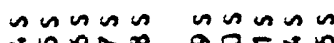

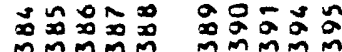

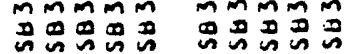

non $n$

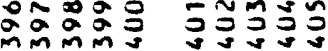

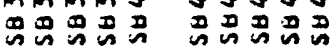




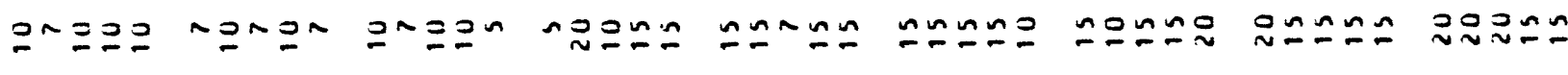

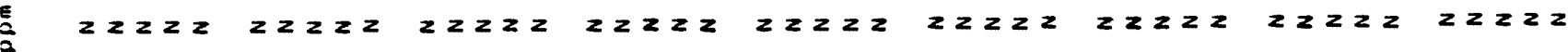

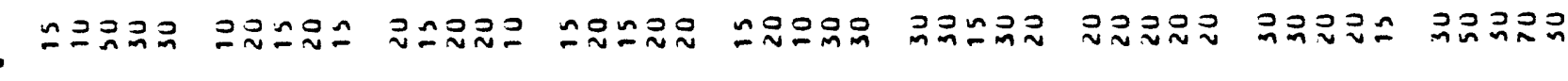

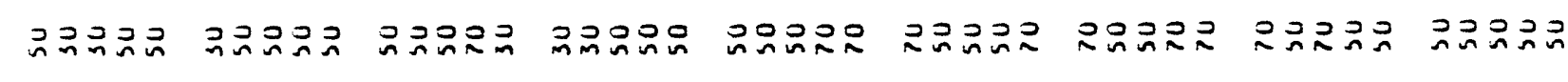

$\frac{1}{2}$

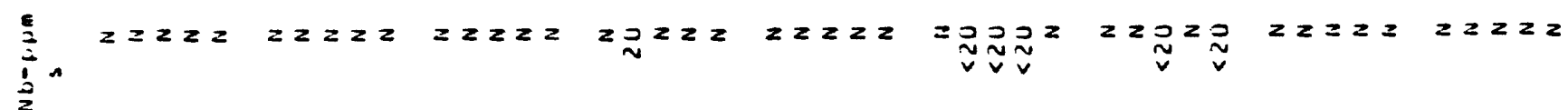

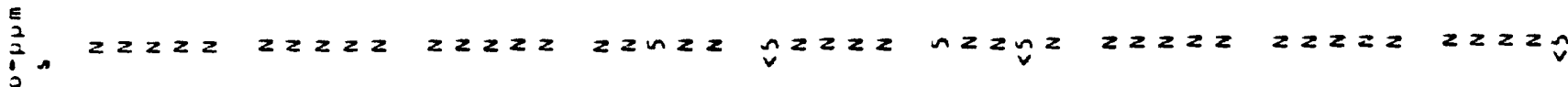
$\frac{2}{2}$

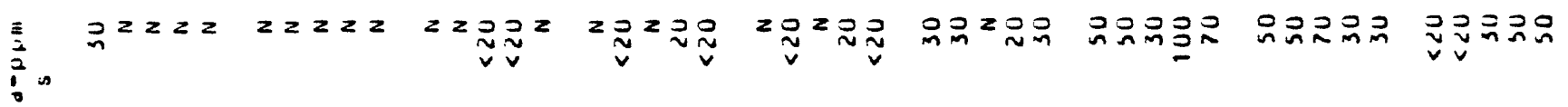

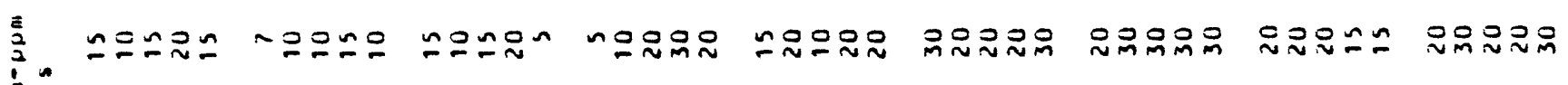

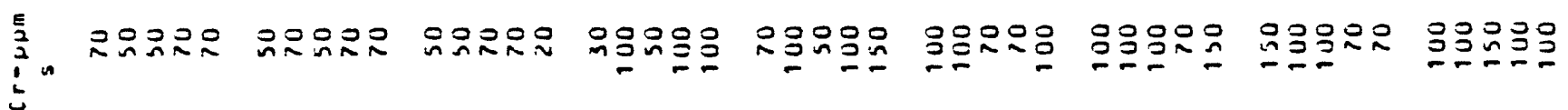

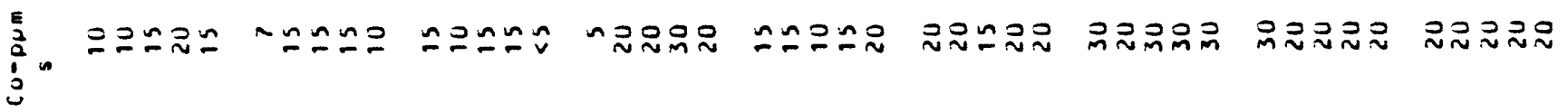

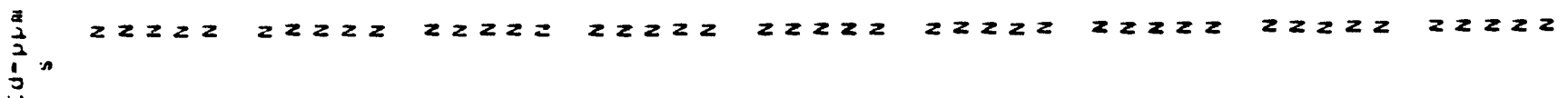
ร

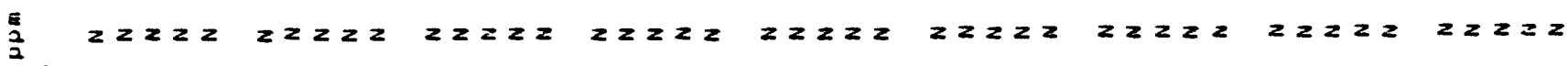
$\frac{1}{3}$

彳

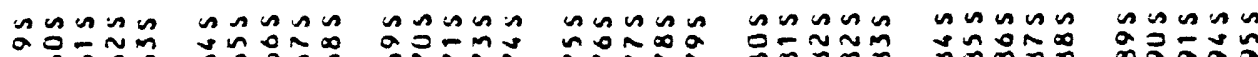

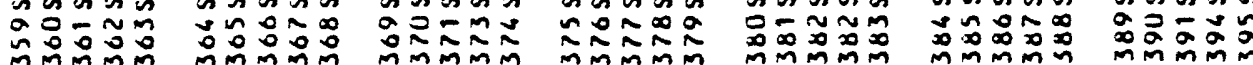

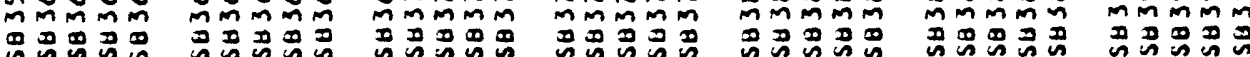

nun on nising

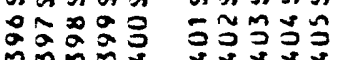

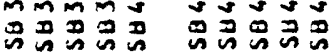




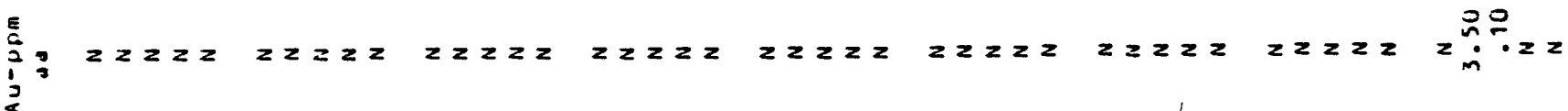

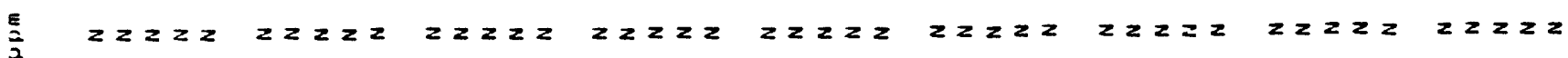
$\stackrel{!}{=}$

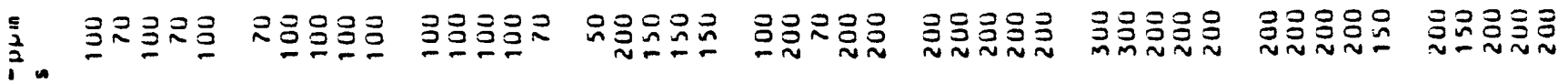
$\div$

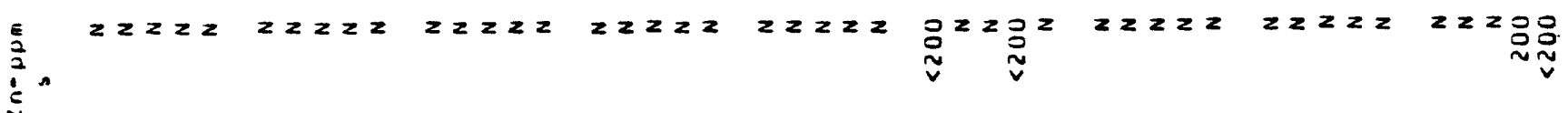

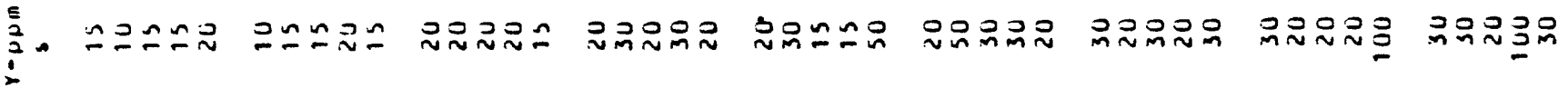
否

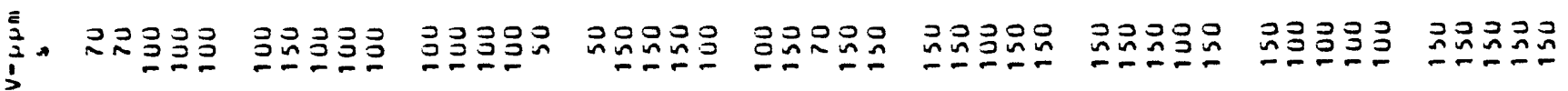

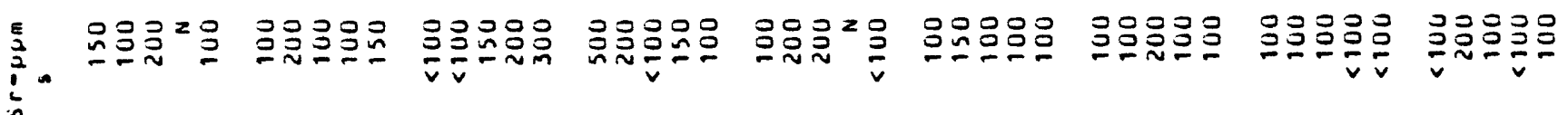

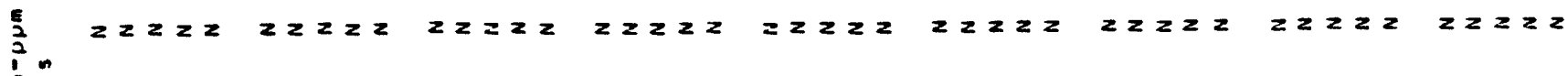
is 


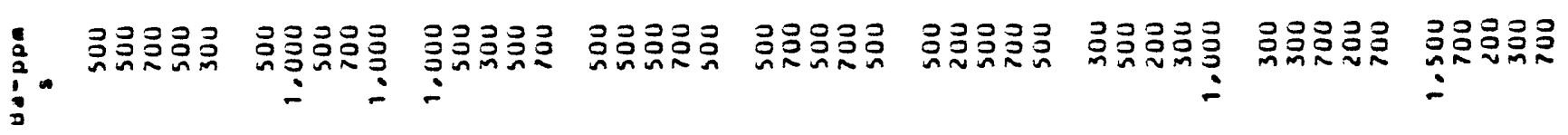

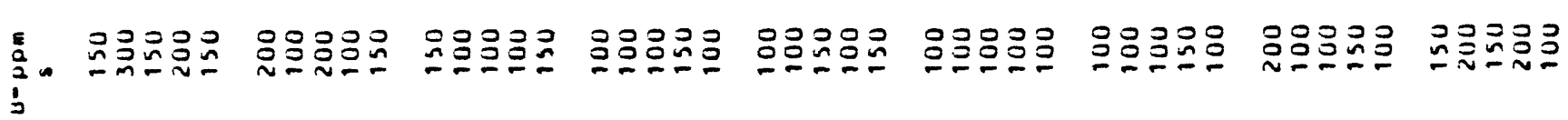

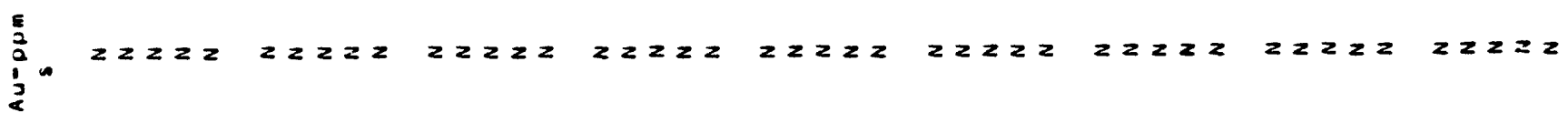

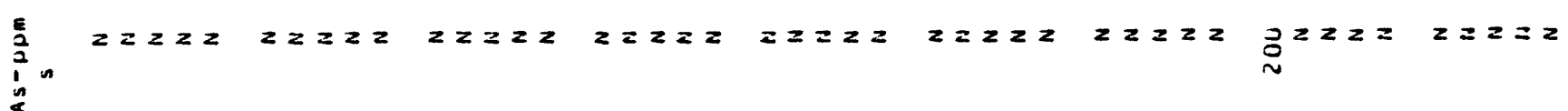

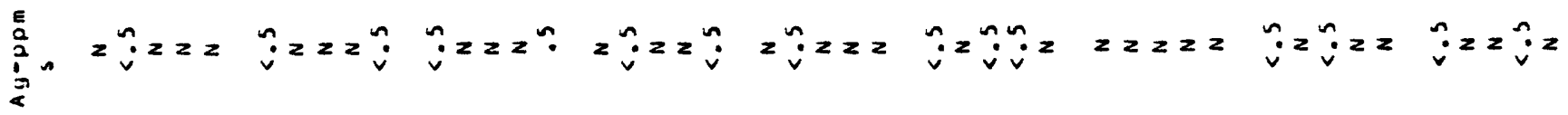

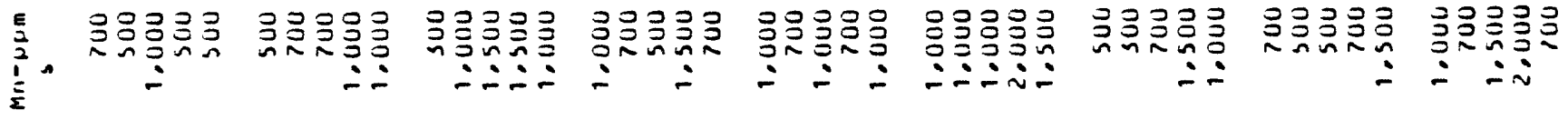

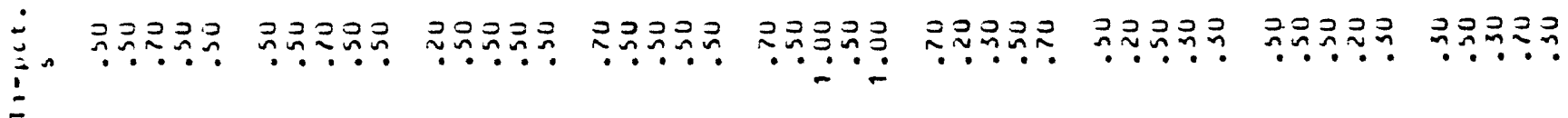

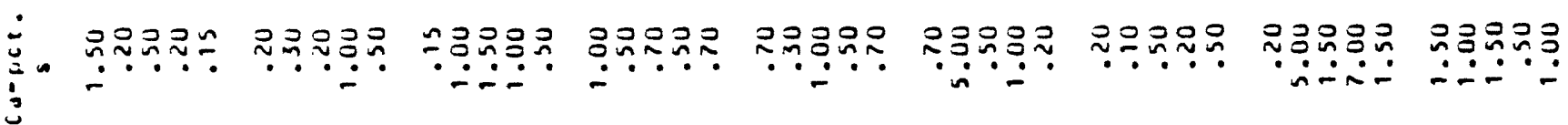

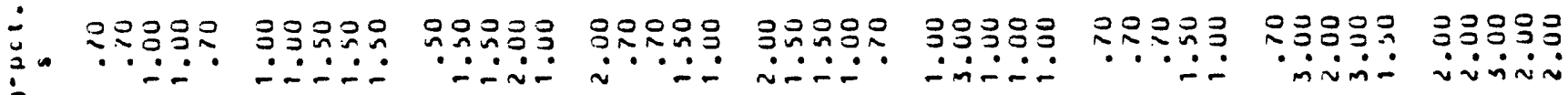
$\frac{1}{2}$

- 0?0?? 0000? 00?0? 00000 00000

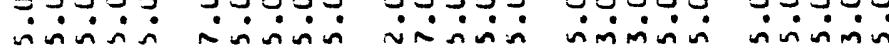

ด๐วดว

?อ?ดอ

$0000=$

?อ?ดว is

ปก

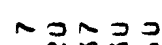

$n n n n$

จึก๊ ำกำ?

nons กmma

nm-n

วกนก

and

$\tilde{n} \sim \sim \mathcal{M}$

วูำ

กี่ากล

ทีกวณn

ํํำำำ

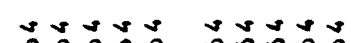

a․․․․

$=\sim 20$

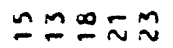

mำกำ

ํํํ음워

- - - 드는

○ำ

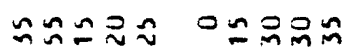

$g \approx \approx 0 \approx$

ำกำกี

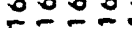

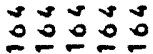

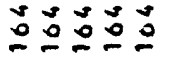

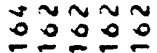

กับำำ

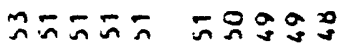

定是婇

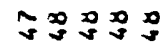

กำนก

ถேกฺน

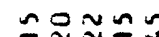

จะกヘะ

ดำกีกำ

o.0.0.0.

o.

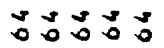

จำธนีก

กี่กี่ปี่

กำธธูก

ถนก

dands

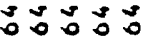

ofos:o

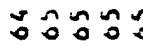

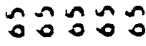

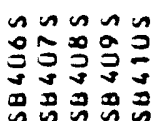

กล⿻ก

$= \pm m \pm n$

nonson

$\div \div \infty 0$

non no

$\tilde{\sim} \tilde{\sim} \tilde{\sim}$

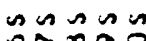

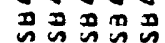

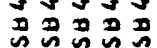

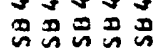

ํํㅇํㅇำ

㤩品总品思

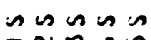

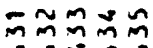

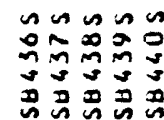

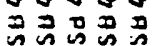

non is in

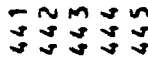

in non

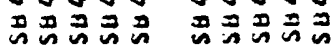


:

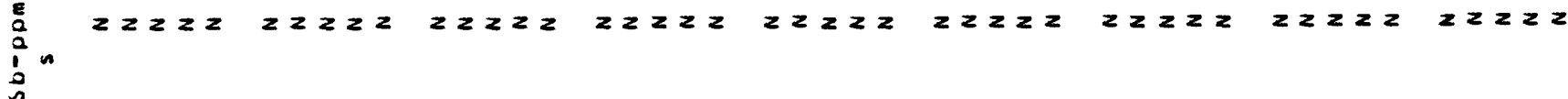

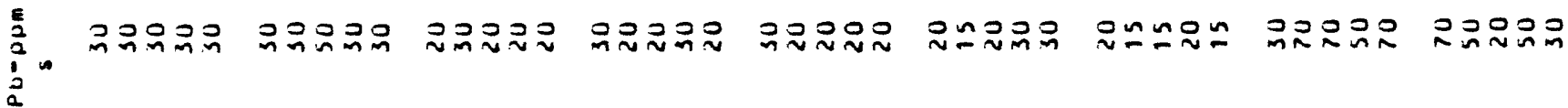

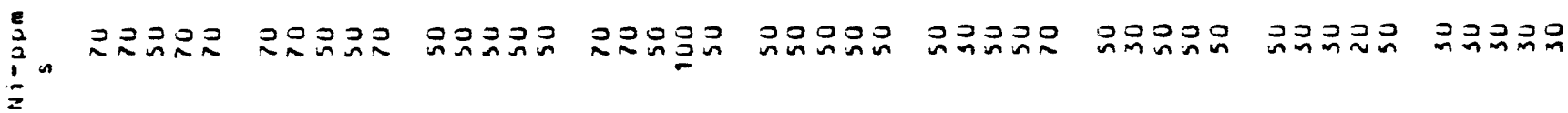

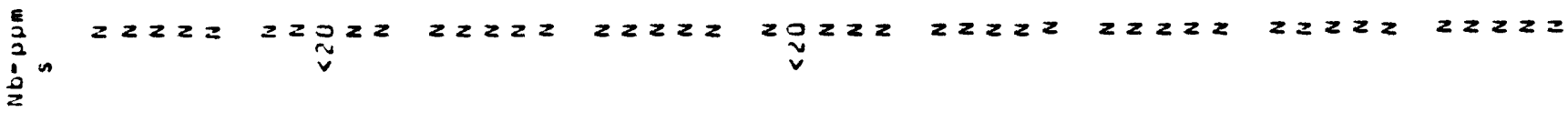

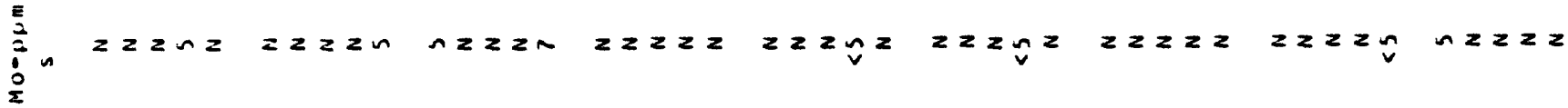

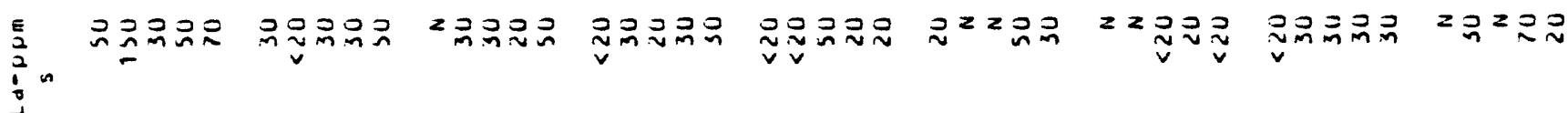

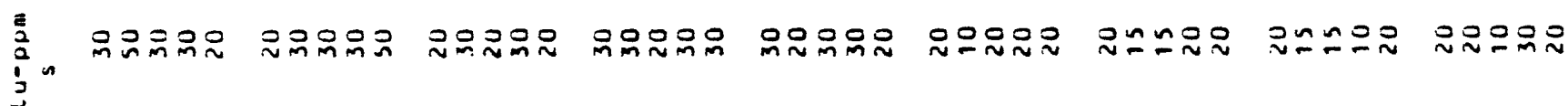

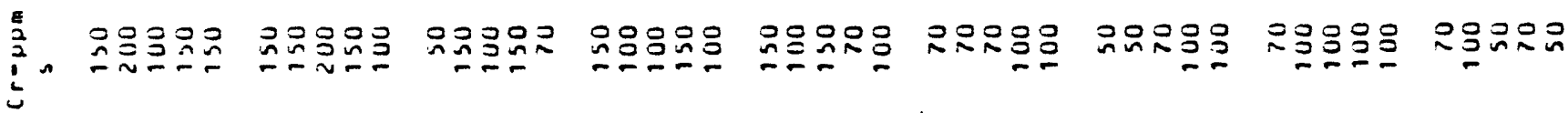

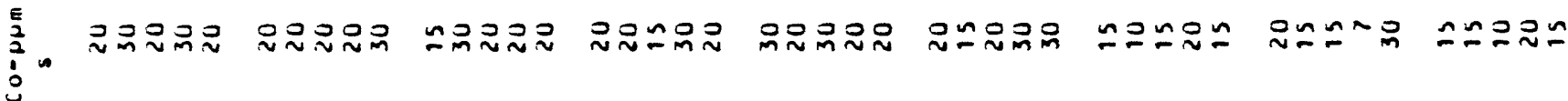

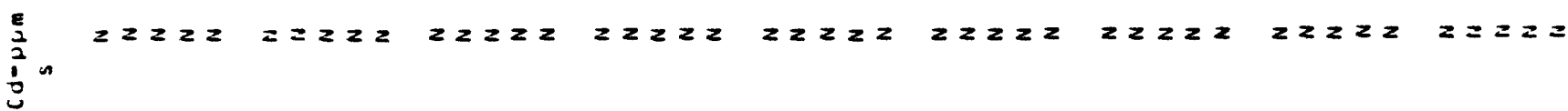

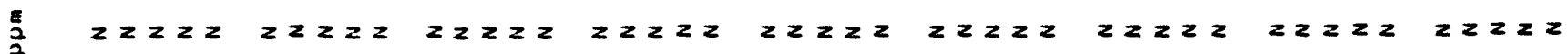
$\frac{1}{2}$ 


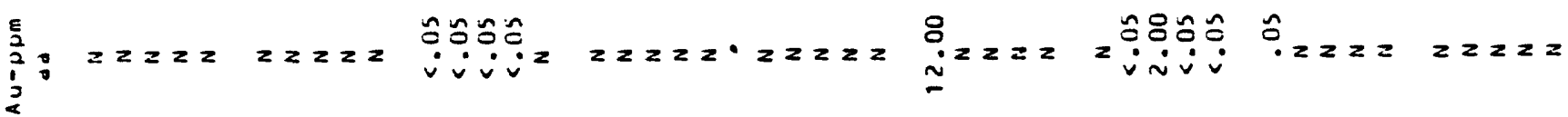

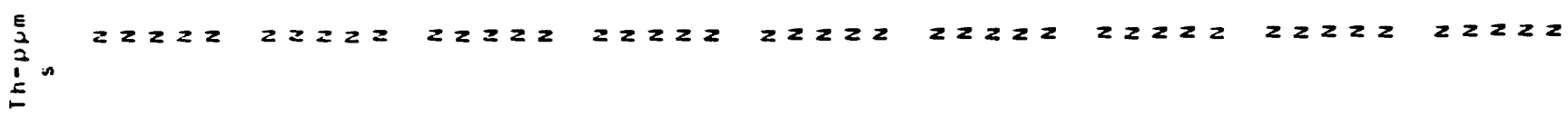

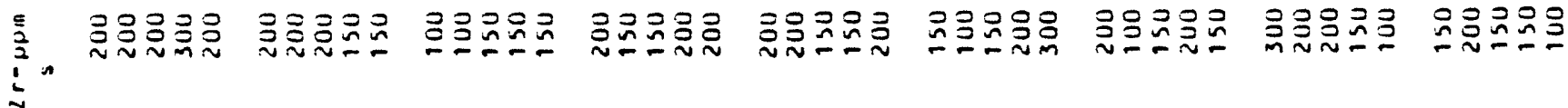

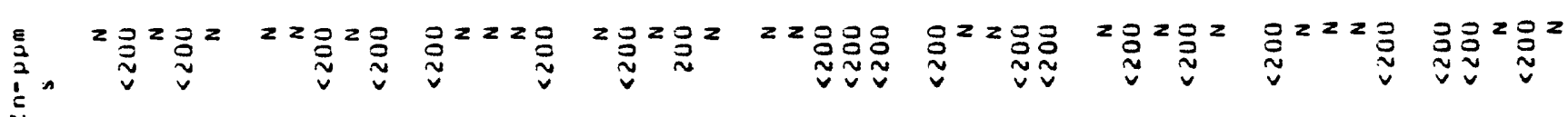

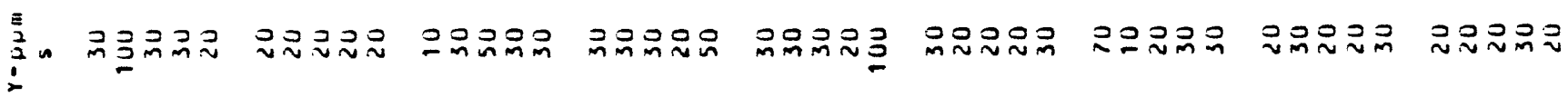

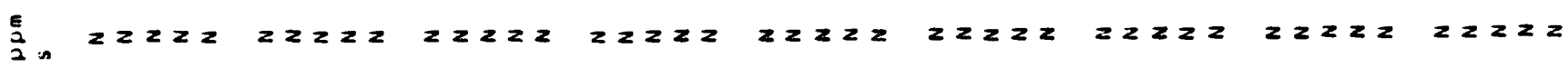

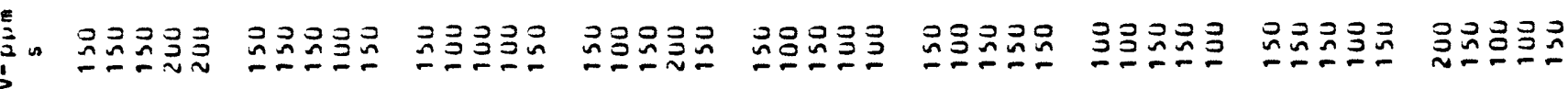

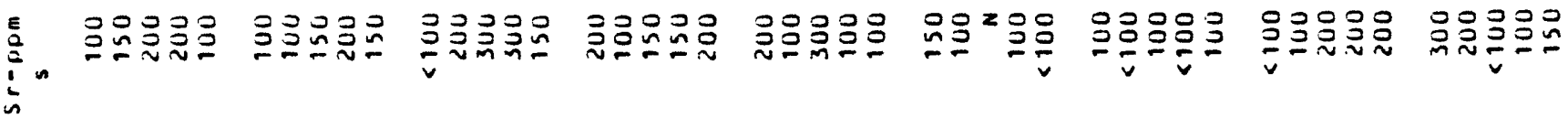

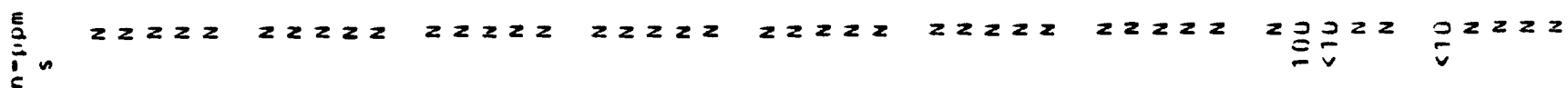
- vonusa cosina

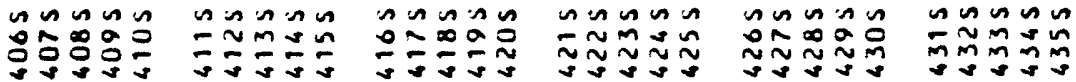

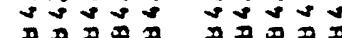

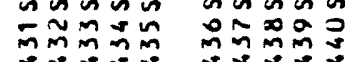
คำ

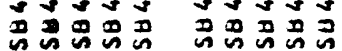


:

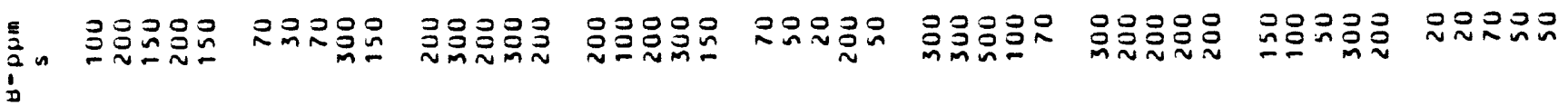
帛

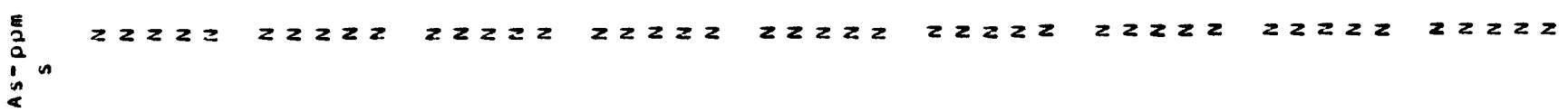

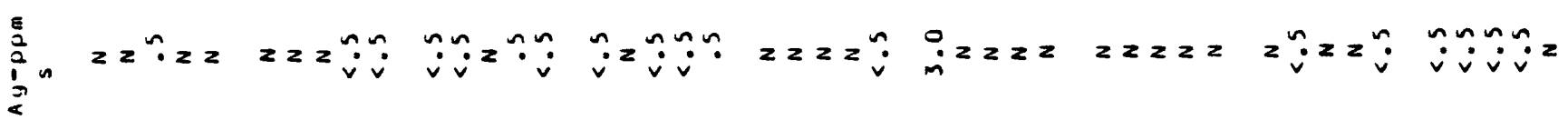

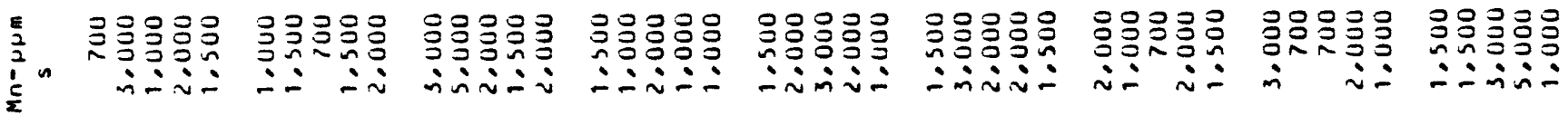

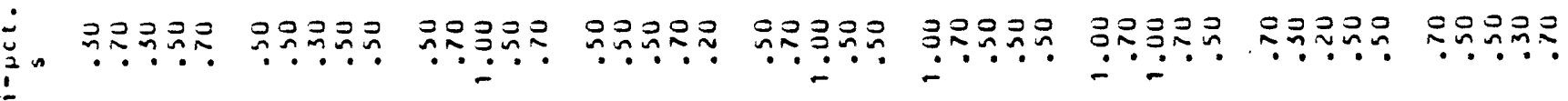

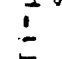

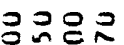
$\because \div$

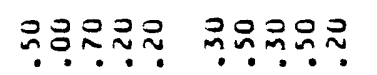

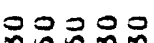
음요온

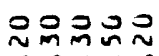

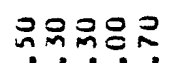

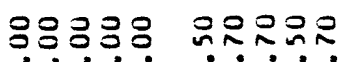
$\therefore-$

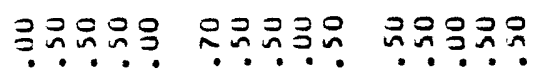

응요웅응 응응요 웅으요

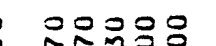
$\dot{\sim} \because \because \because \because \because \because \dot{\sim}$

0000 00?0? 0?:0? 09000

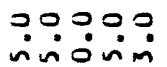

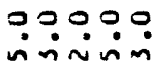

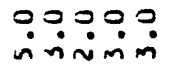
ini iि? ?ำ? ?.?

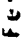

กำํำ

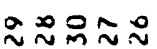
ํํำ

$\hat{\sim}=\backsim n \approx$ ヘกペ

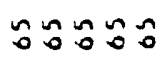
르ํํํㄹำ 으요 คิดี่อัด

กำㄴ กล⿻ำ กับก: jo:0j:

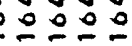
ก์ธฺุะ

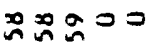

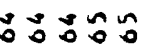

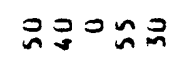

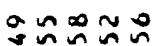

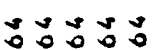

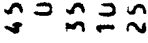
袺放的

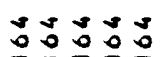

ำณำ

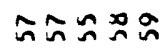
वृ.0.
踶品沓品 nmman

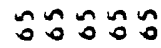

กีณกฺะ

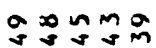

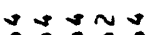

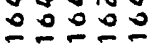

음ํํㄱำ mง n กิธิดีอ
กุกที่กิ $\sim \approx \infty \sim 2$

$\sim \sim \sim \sim \sim$ 으은
궁ำำ

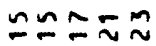

$\sim \sim \sim \sim \sim$ 으은
กุヘกュะ ํํำกm $\sim \sim \sim \sim \sim$ Oำ은

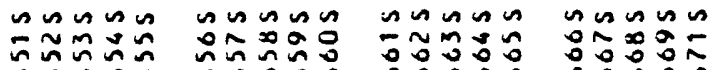

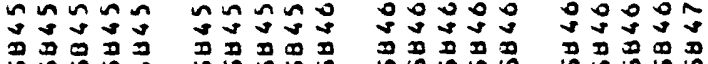

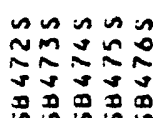

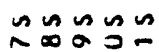

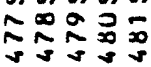

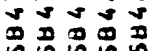

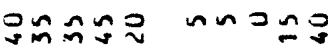

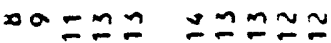

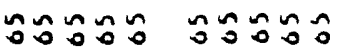




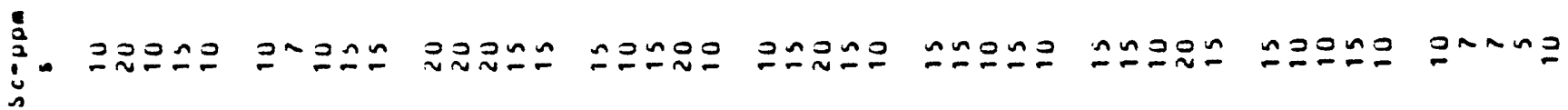

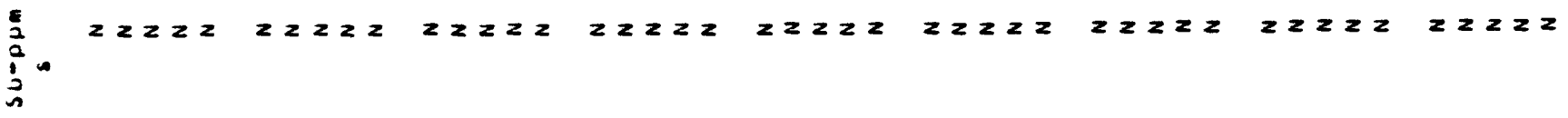

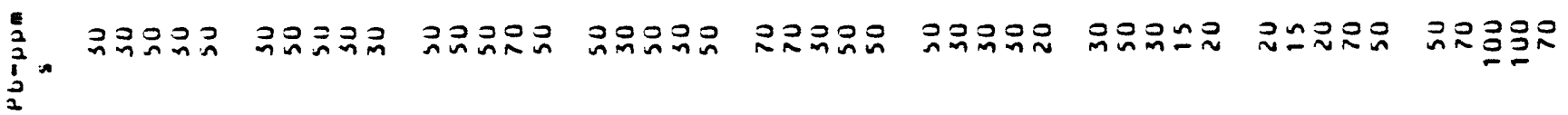

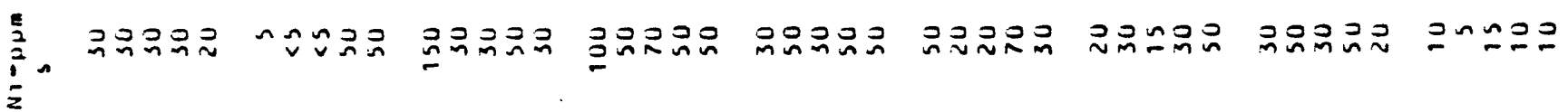

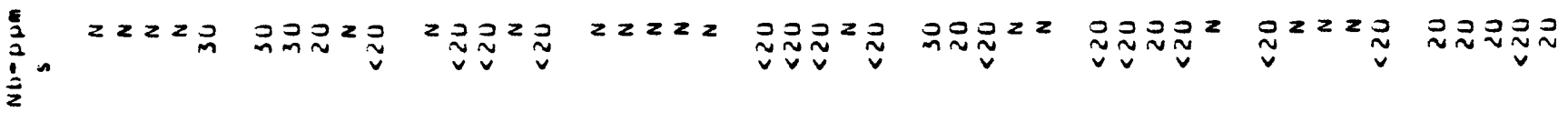

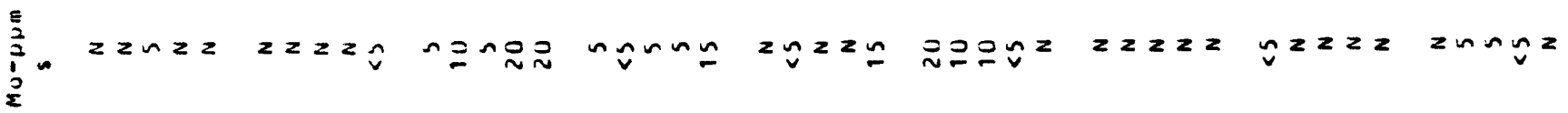

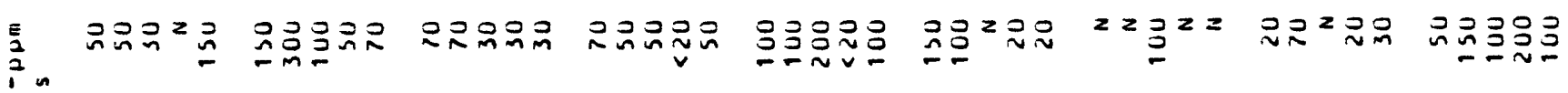

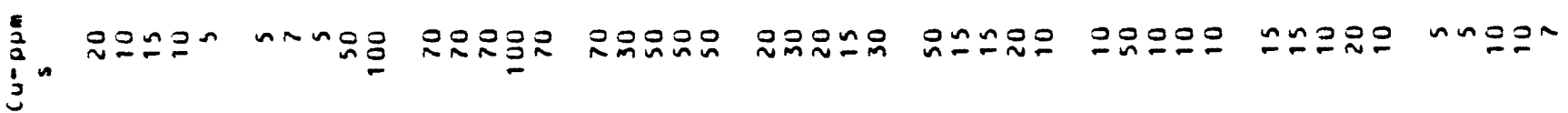

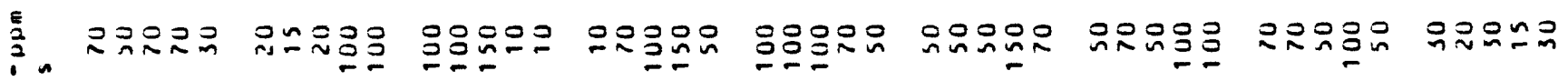

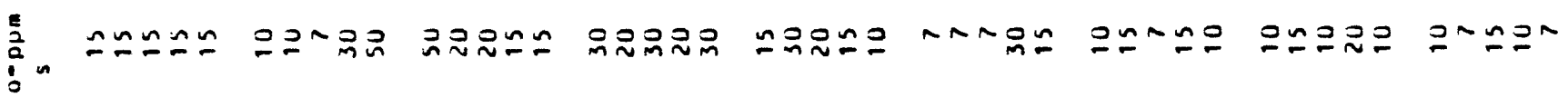

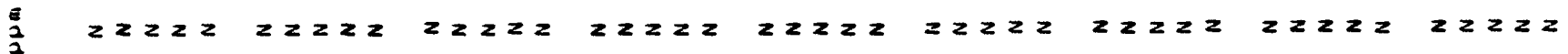
ב⿱艹

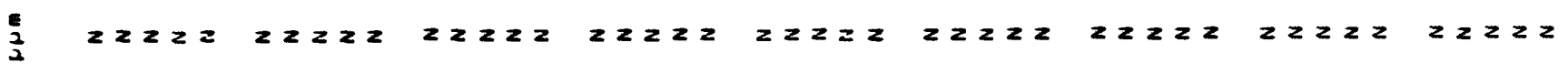
के : 量

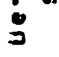

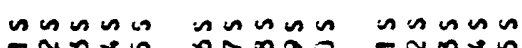

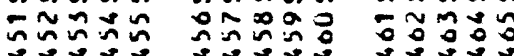

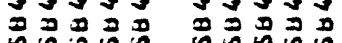

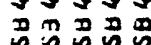

กนกนก ำㅇำ

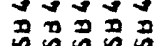

nก⿻上丨丶

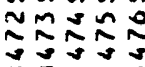

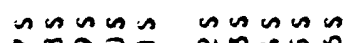
ก⿻上丨 i.tis.

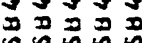

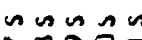

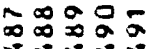

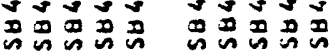




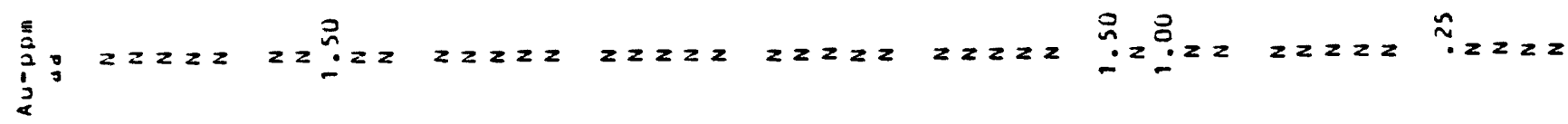

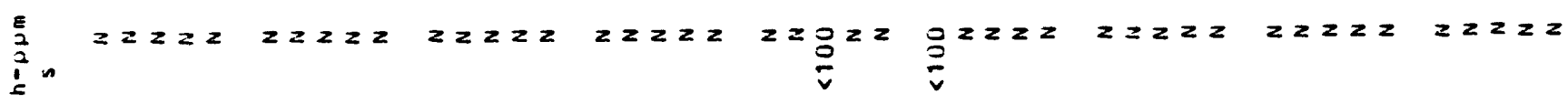

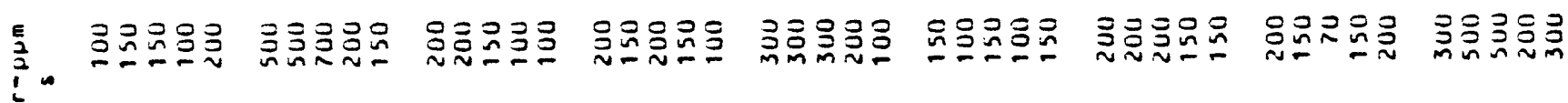

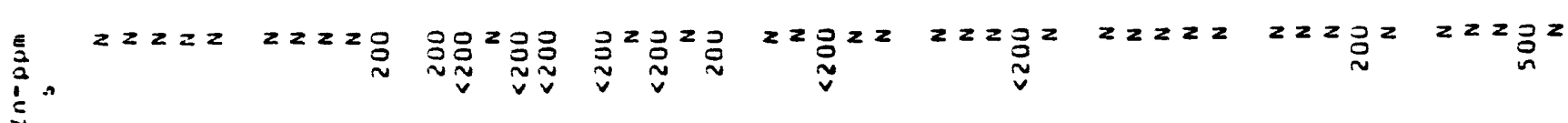

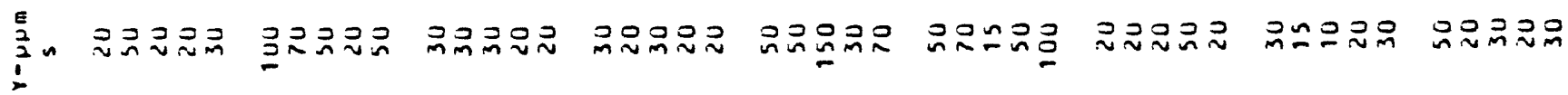

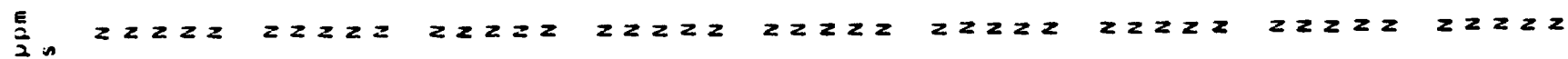
3

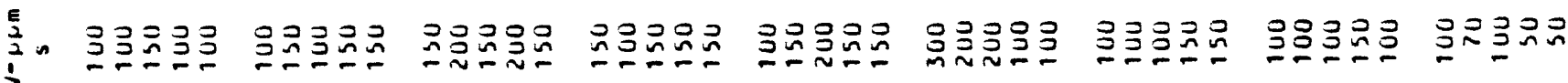

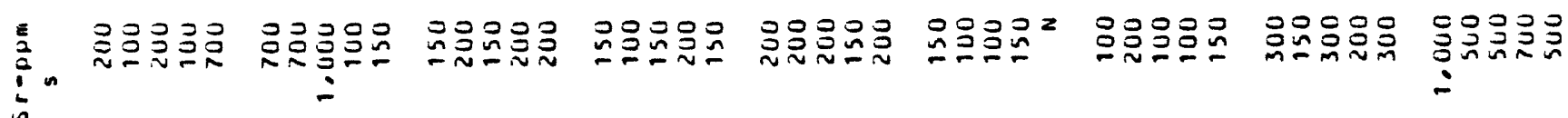

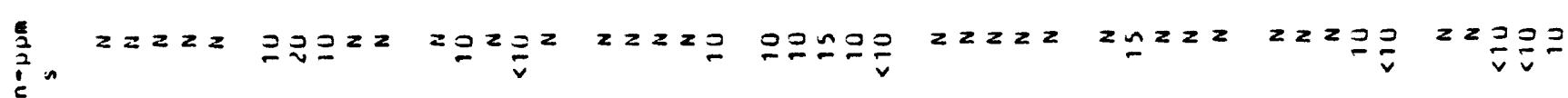

nn $n$ no

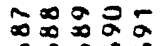

a

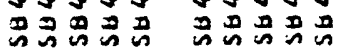




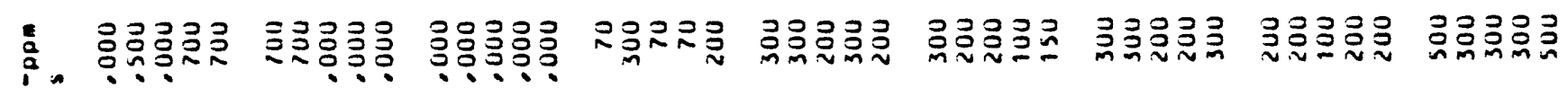

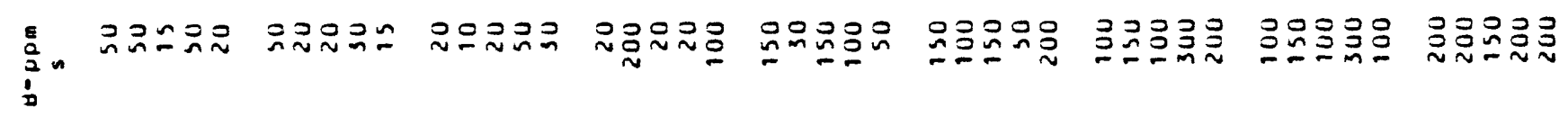

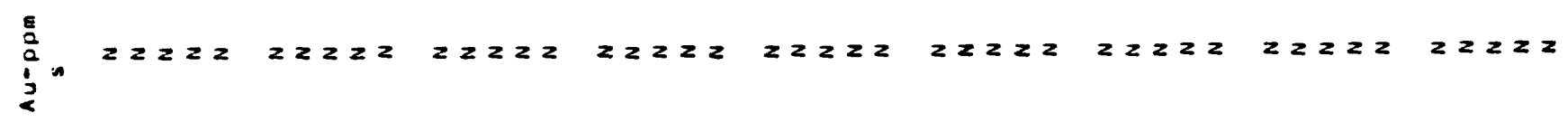

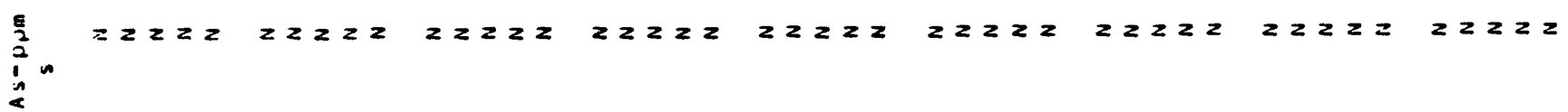
方.

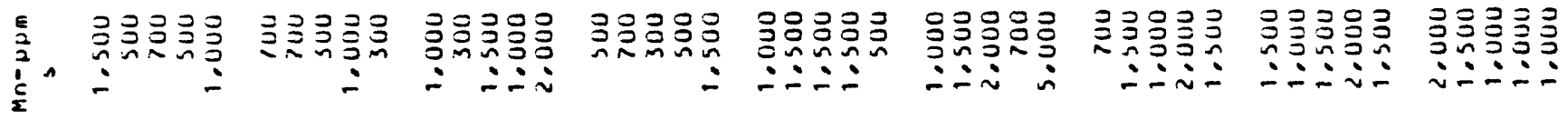

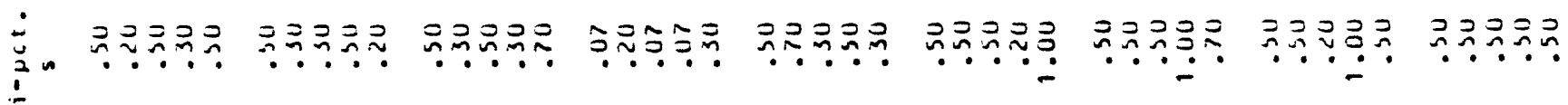
$=$

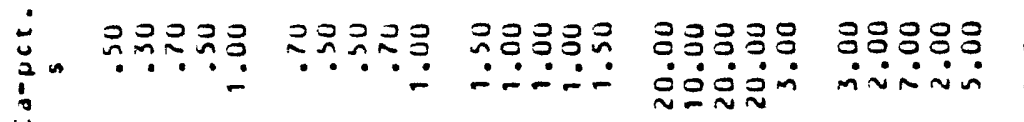

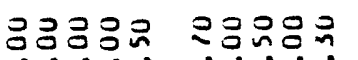
mini $\dot{0}-$ $\because \because \because \div$

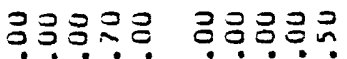
$\sim$

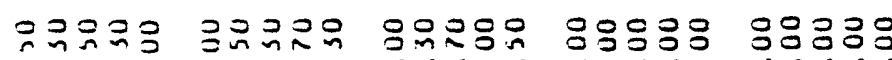

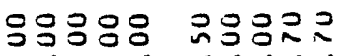

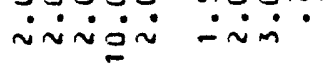

ㅇํㅇํํ 马马ํำ ind ทำ? ... ․․

inisin

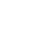
$\dot{\sim} \dot{\sim} \dot{-1}$

ด:?? ?:?ด:?

$0 . ? 0 ?$

$? ? ? ? ?$ $\dot{j}_{\dot{j}}$

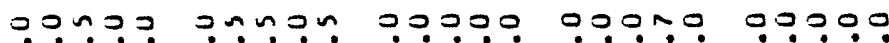
m-ஃim nivinininn $\sim \sim \sim \sim \sim \sim$ inimin

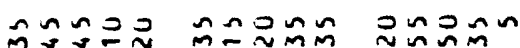

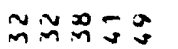
a.̃ $\sim M n$ $\infty \infty \sim \sim n$ nิnก⿻ำ nOก๊ำ

วำำกำ in

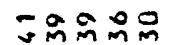
으ํํำm

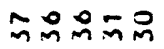
m

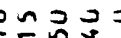

$\sum \approx \tilde{ท}$ บ $\sim \sim \sim \sim \sim \sim N \sim$ N $\sim M m M$ $\sim \sim \sim \sim \sim \sim \sim \sim \sim \sim$

$\sim \sim \sim \sim \sim$ ำำำ

MMM̃̃ Inูง $\because \div 0 \div$ $\div 0 \div \div 0$ $\because \div 0 \div 0$

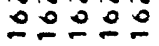
$\because 200 \div$

$\div 0 \div 0$

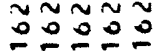

$\sim \sim \sim \sim \sim$ $\tilde{0} \tilde{0} \tilde{0} \tilde{0}$

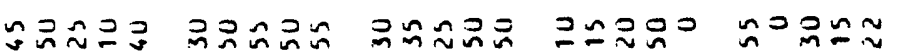

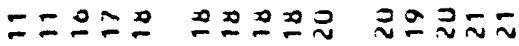

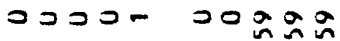
อกทบบท

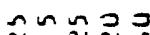

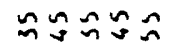

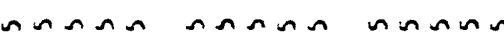

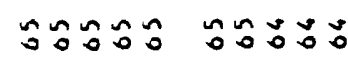

กำกลก

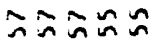
คินกีนกูก กีกีกตูกี่ กิดภิดน

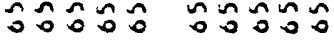
กัน

ถึก 충ํํำ

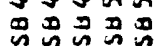

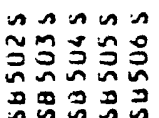

กีกนก

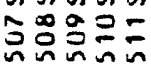
召品思召㐘

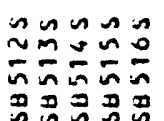

กินกน ำㅇํำ 品品品思品

คก $\tilde{\sim} \sim \tilde{\sim} \sim$

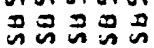

in $n$ in in

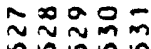
品寻品吕品

in $\sin n$

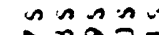

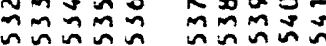

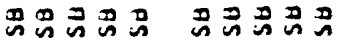


i⿱

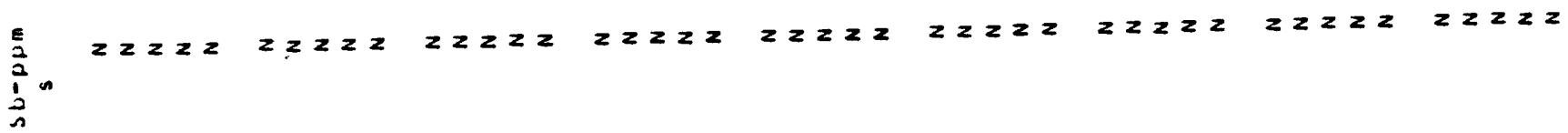

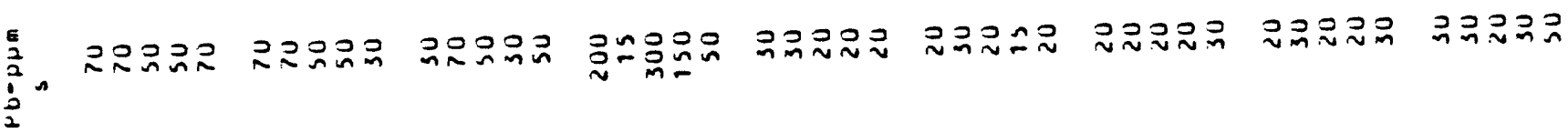
E

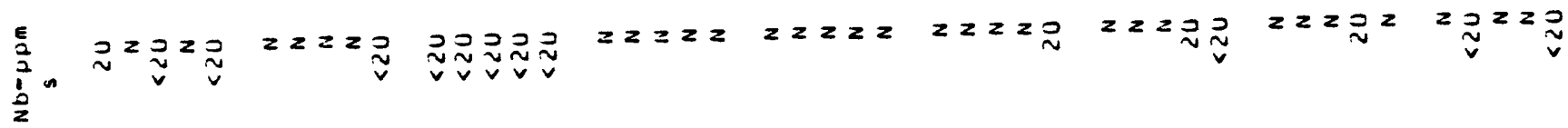

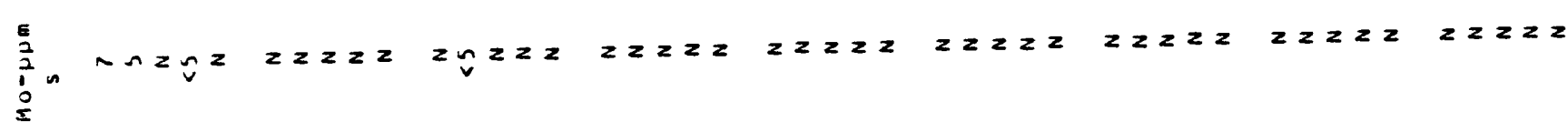

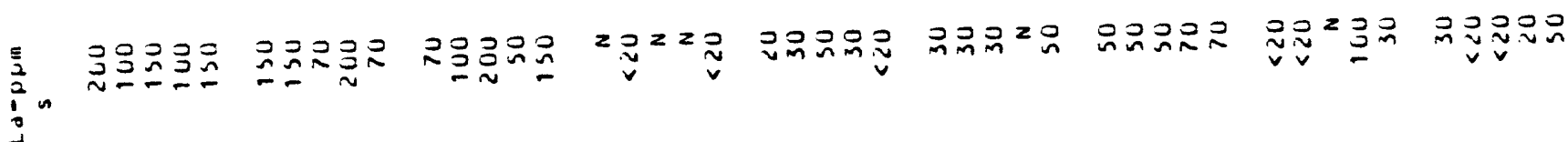

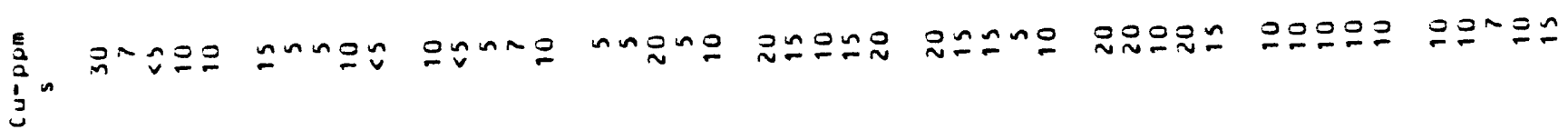

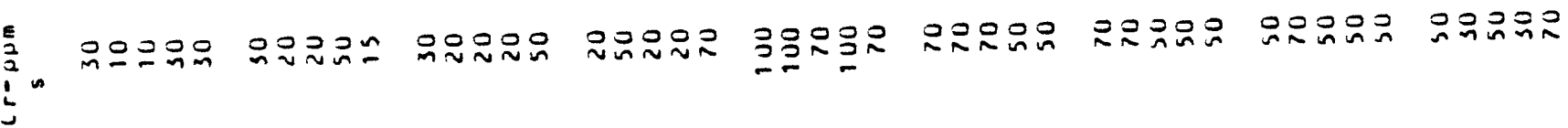
E⿱

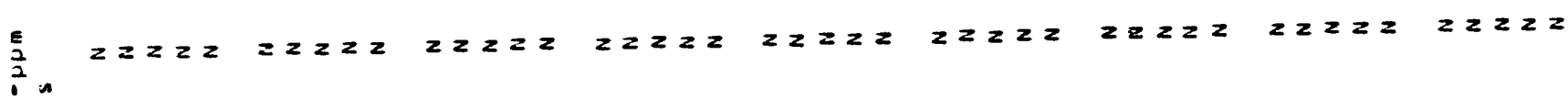
3

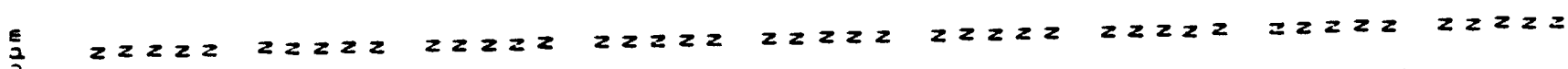
$\frac{2}{2}$

$0: 0 ? \dot{0}$
in

00000

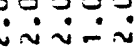

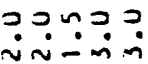

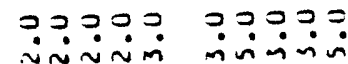

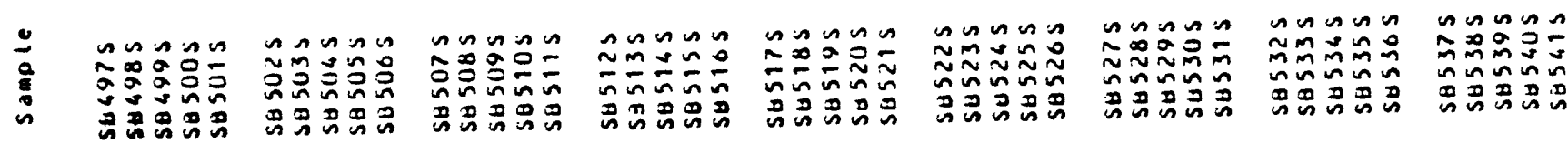


焉:

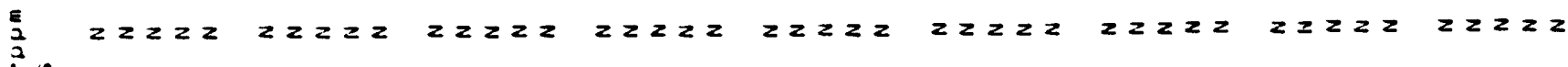
$\stackrel{1}{=}$

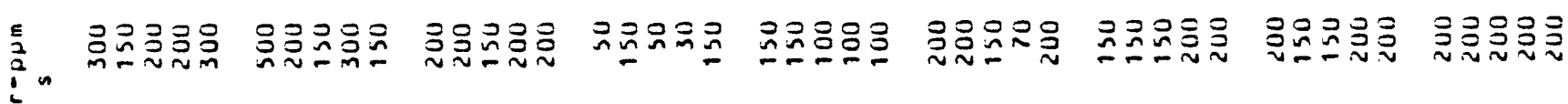

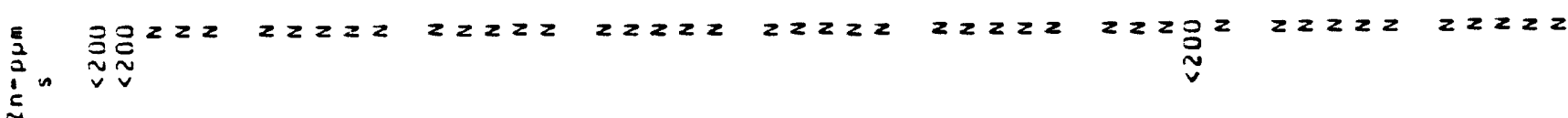

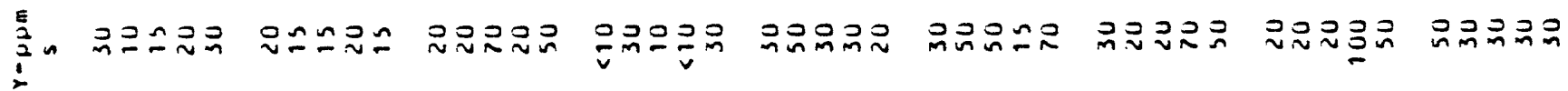
竞

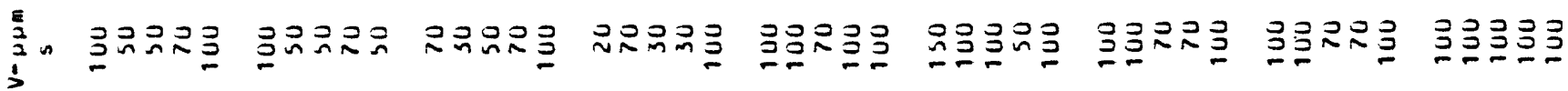

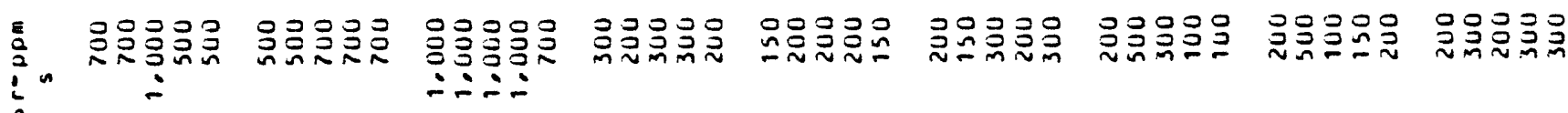

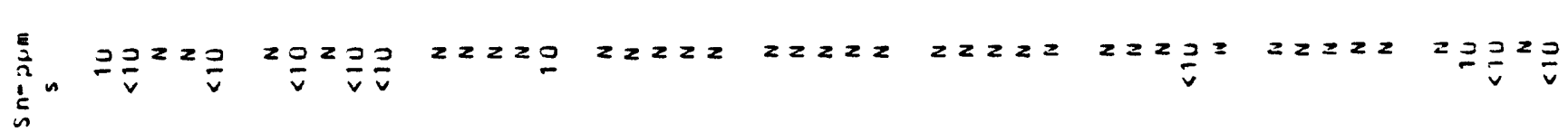

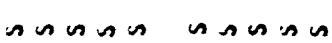

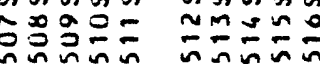
$\sin \sin \pi$

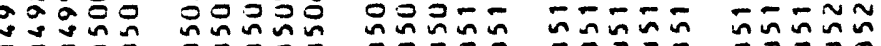

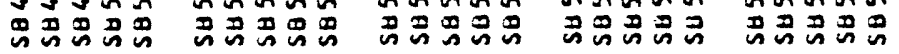

insing $\approx \tilde{\sim} \approx \approx \sim 0$

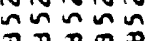
蛋品召品品

uningu nisung

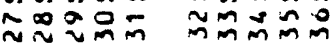
ninniñ

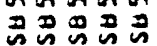




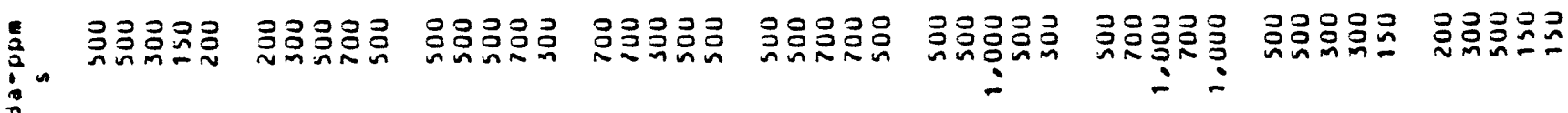

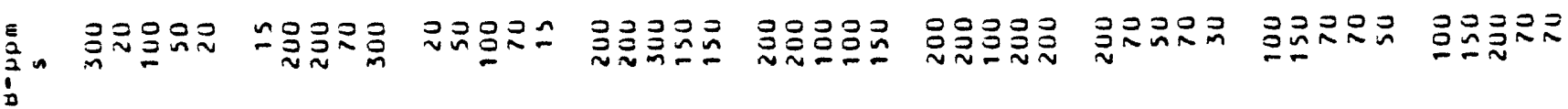

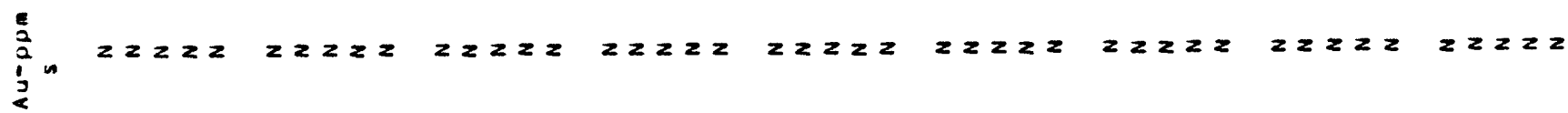

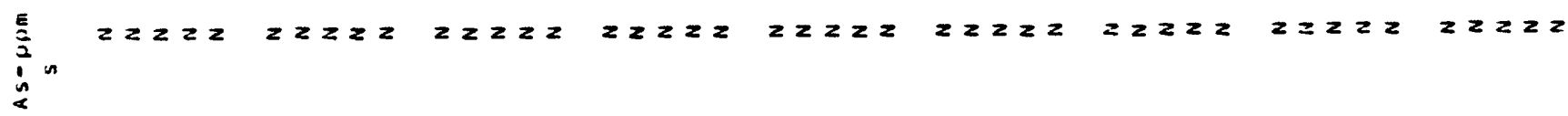

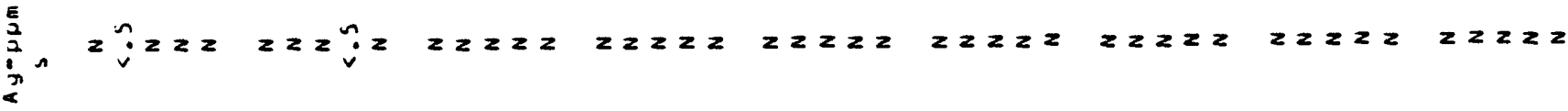

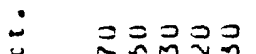

곡ำ

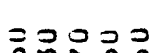

륵오웅

국공ㅇㅇ

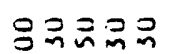

ํํํํํำ

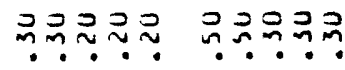

$\dot{2}$

$\stackrel{\vdots}{\vdots}$

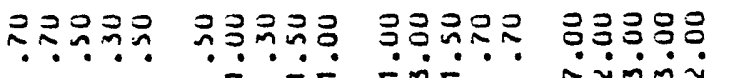

응으문요

웅요응

ํㅠㅇํํํำ

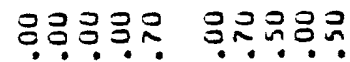
i

-

जि-

vimmi

imi-:-

$\therefore$ ini

$\because \therefore \sim r$

inini

$\because \dot{\sim}$

$\dot{\frac{3}{2}}$

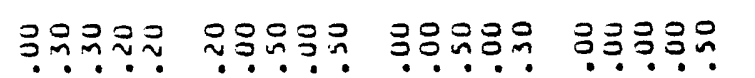

응응요요

응요응

옹유옥

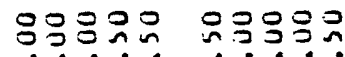
$-$

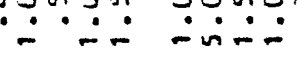

iñ⿻ -

- Nn--

- - in

$-\sim n \sim$

$\dot{\sim} \dot{\sim} \dot{-1}$

- $\dot{\sim}-\dot{0}$

00000

?:?00

00000

?0?00

00000

00000

30000

00000 009?0 in $\dot{x} \sin$ nñnN

nnnmin

nnnunin nnmin

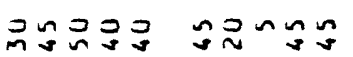
윴윰유

ธีอะก 욲뮤유

$\because \div \div \div$ ํํำำ

คำกฎี ษำํำ

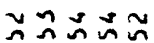

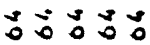

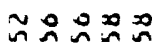
a.j. ms?

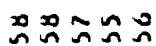

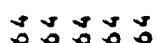

品 00 品 $==\sim 0$ 응

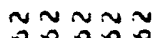
ํำ ํํำำ กีคณีคำ ง้ํํำก

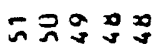
7.0.0.0.0

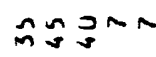

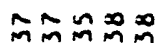
บก ก 으는 . R.
ดูะะี 的的的品 $\because \tilde{0} \simeq$ :

을ํ요

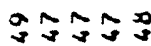

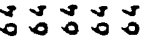

ㄱํㄱำ

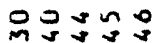

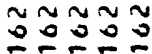

กิวละณณ

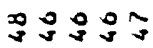

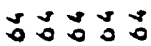

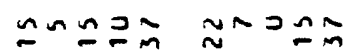

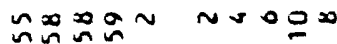
$\sim \sim \sim \sim m$ mmmmm

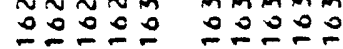

ำจะก๊ำ ำง

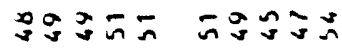

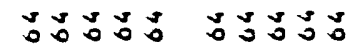

innosing

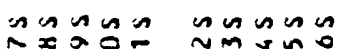

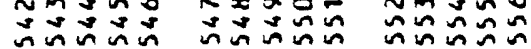

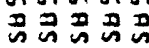
召通寻品昆

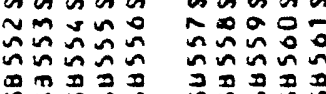

nก⿻上丨

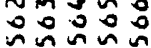

กนกะน ㅇํำ

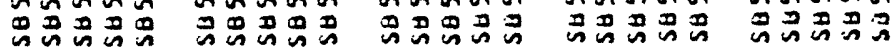

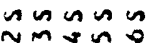

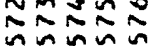

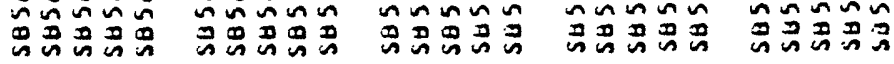

nus in in in in $n$ is

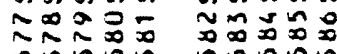

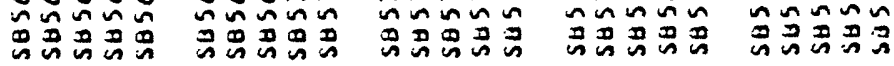




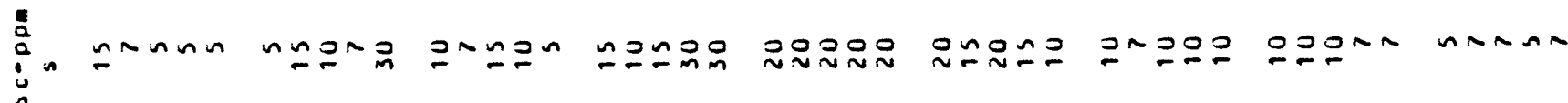

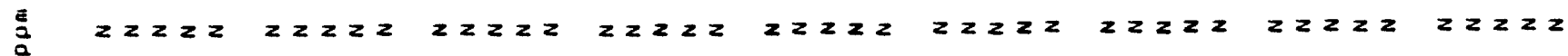
in

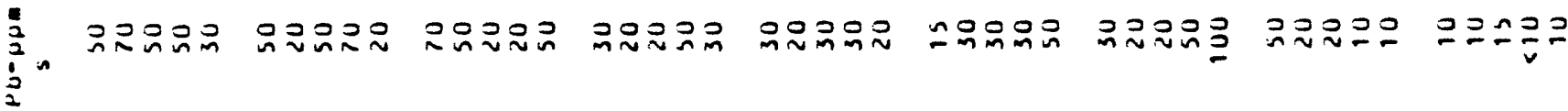

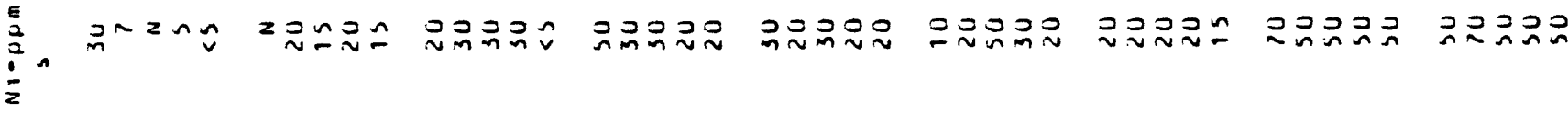

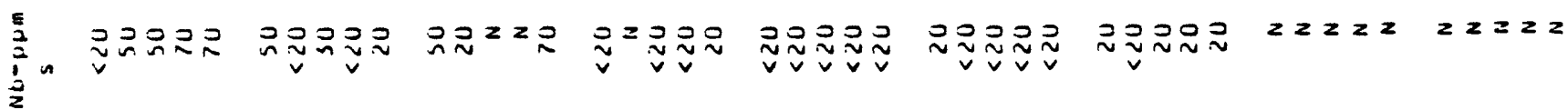

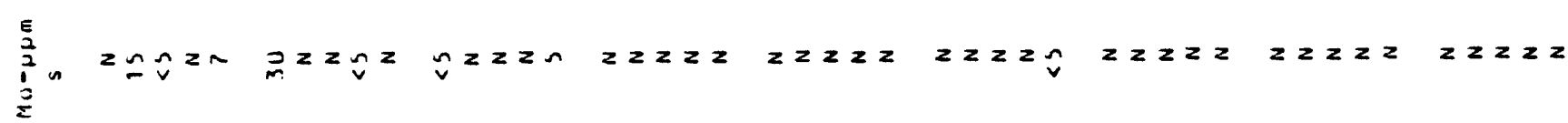

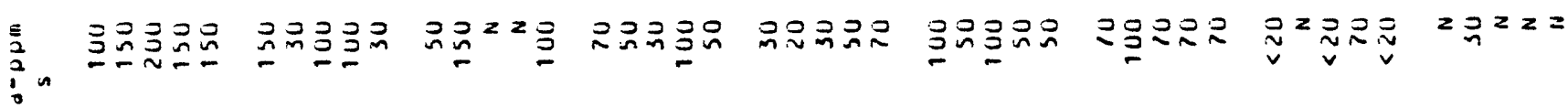
$\stackrel{3}{i}$

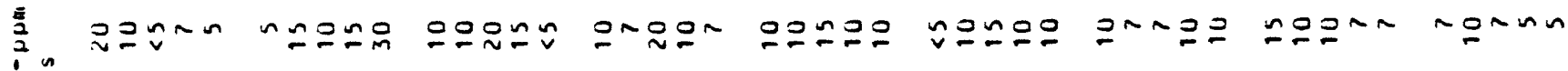
$\stackrel{g}{a} \quad \dot{j}$

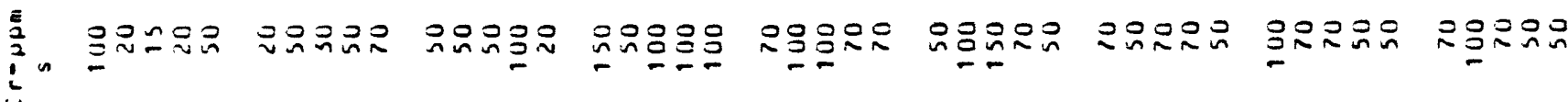

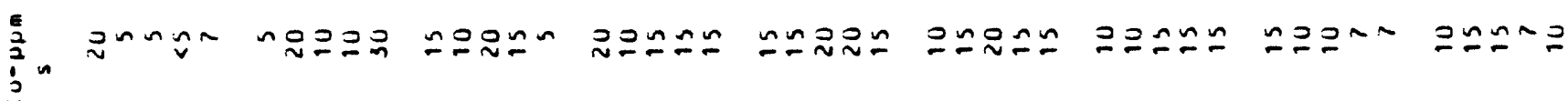

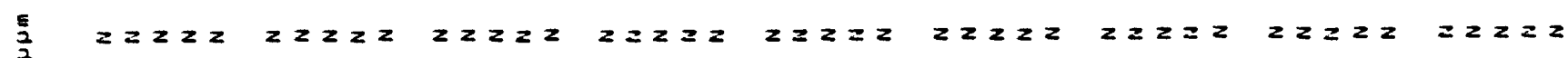
$\dot{j}^{2} n$

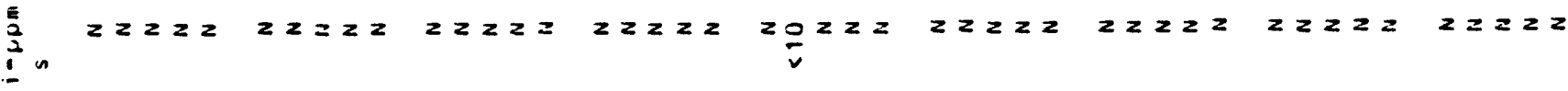
$y$

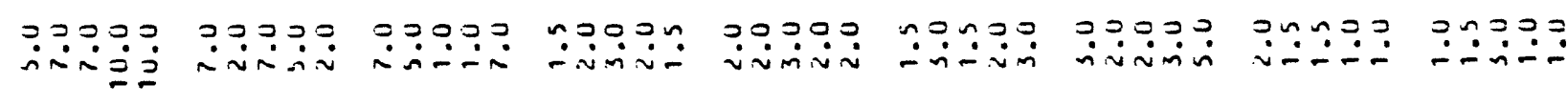

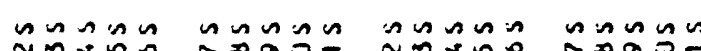

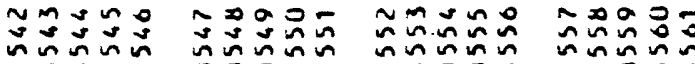

- $\sin \sim n \in$

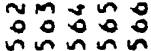

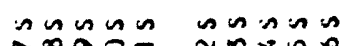

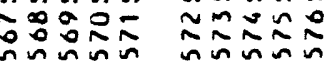

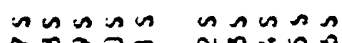

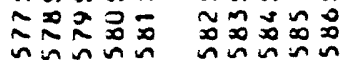

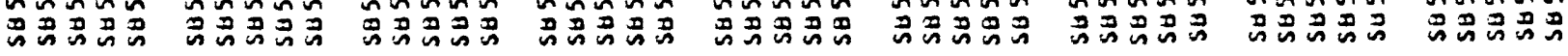




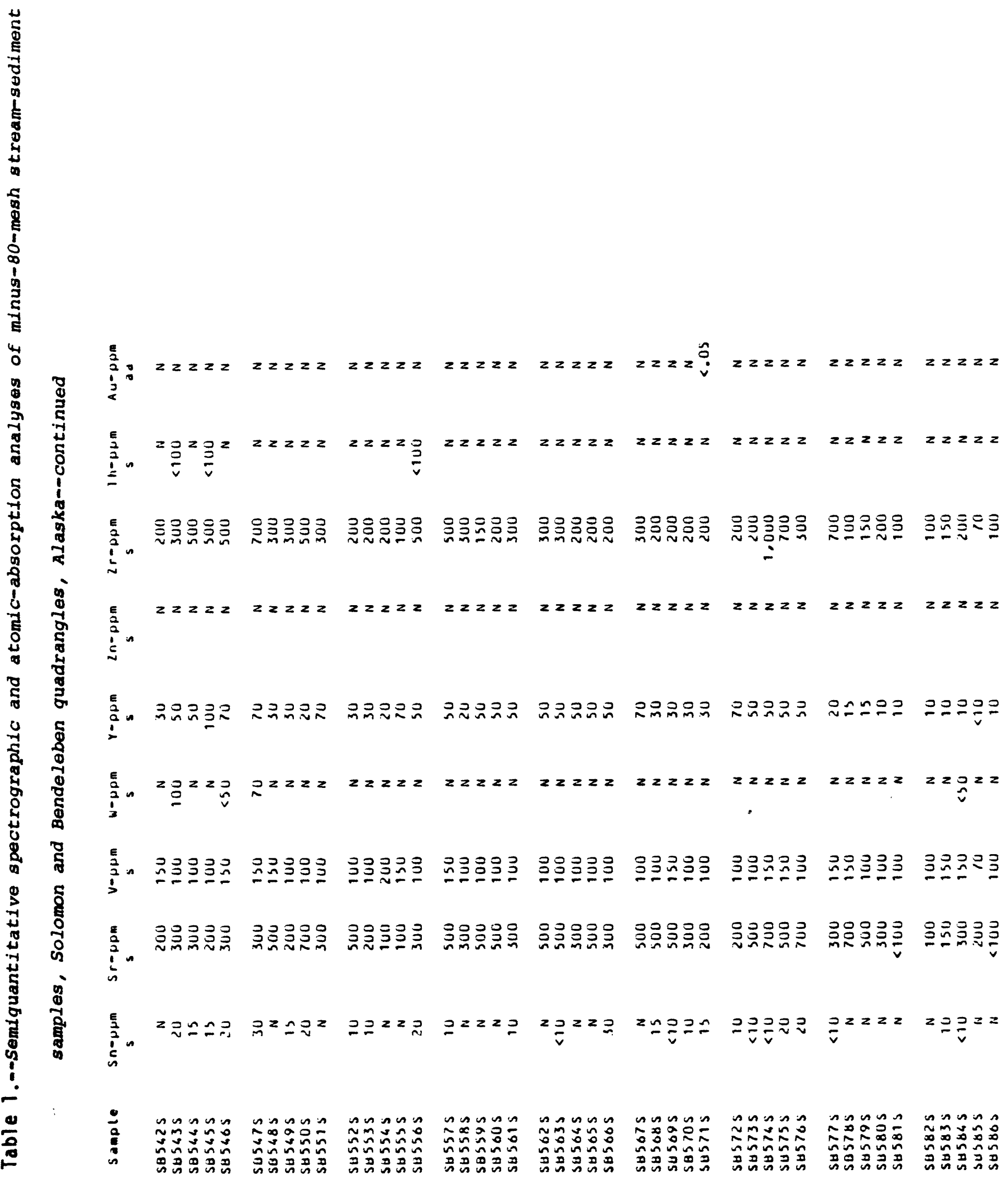




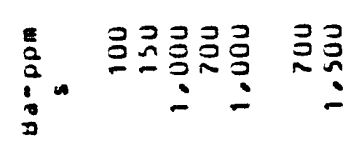

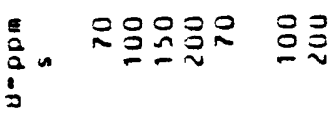

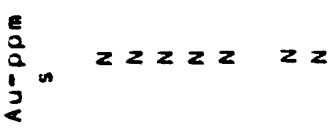

$\int_{\frac{\pi}{2}}^{2} \quad z z z z z \quad z z$

$\sum_{i}^{\frac{E}{2}}, z z z z z \quad z \stackrel{n}{2}$

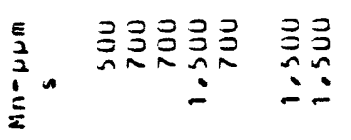

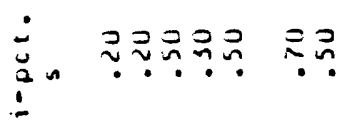

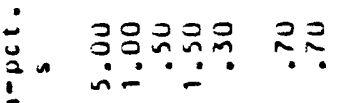

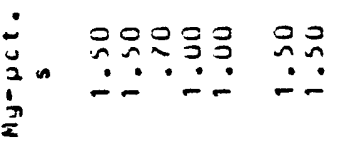

容

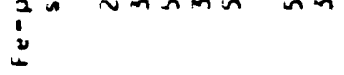

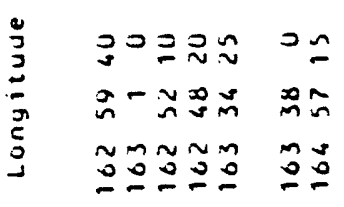

ว

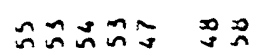

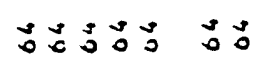

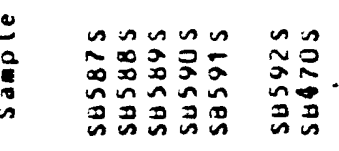




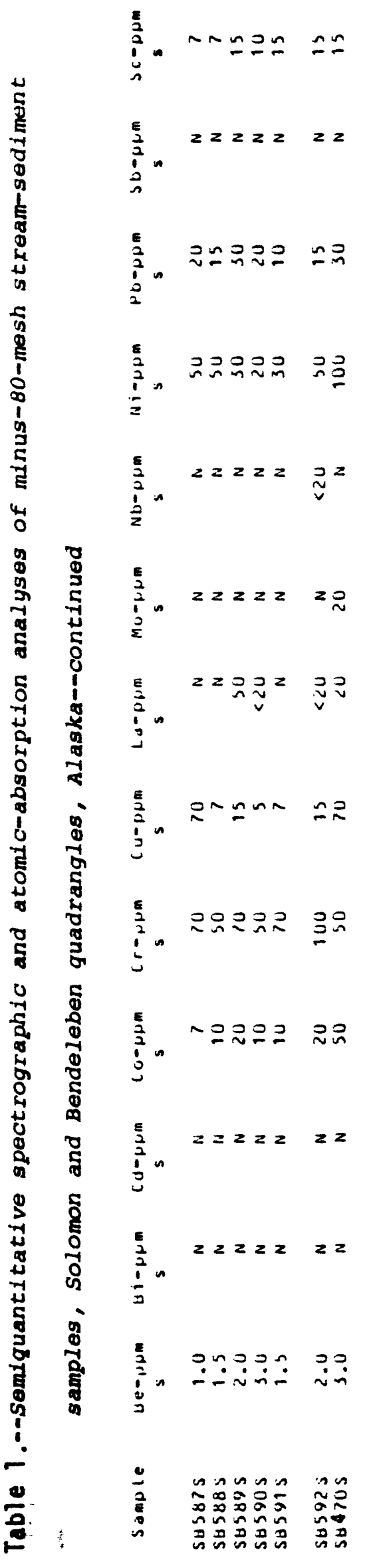




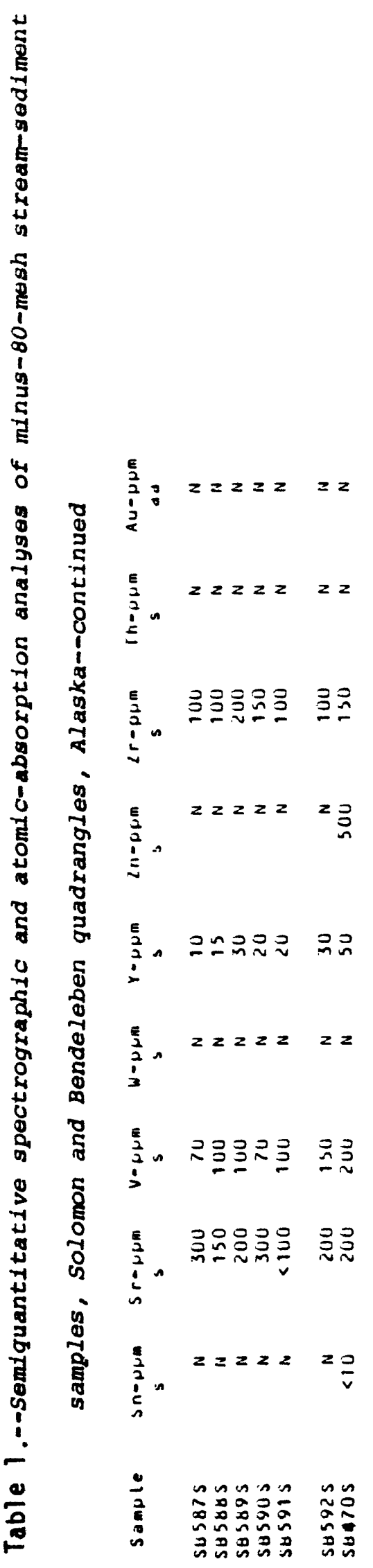

